UNIVERSIDADE TECNOLÓGICA FEDERAL DO PARANÁ PROGRAMA DE PÓS-GRADUAÇÃO EM LETRAS

ÁREA DE CONCENTRAÇÃO: LINGUAGEM, CULTURA E SOCIEDADE

RENATA APARECIDA FERREIRA RIBAS

AS MULTIFACES DE CHICA DA SILVA EM TRÊS ROMANCES BRASILEIROS

DISSERTAÇÃO DE MESTRADO

PATO BRANCO - PR

2021 


\section{AS MULTIFACES DE CHICA DA SILVA EM TRÊS ROMANCES BRASILEIROS}

The multifaces of Chica da Silva in tree brazilian novels

Dissertação apresentada ao Programa de Pós-Graduação em Letras da Universidade Tecnológica Federal do Paraná (UTFPR) - Campus Pato Branco, como requisito para obtenção do título de Mestre em Letras.

Linha de pesquisa: Literatura, Sociedade e Interartes.

Orientador: Prof. Dr. Maurício Cesar Menon

$$
\text { PATO BRANCO - PR }
$$

2021

Esta licença permite que outros distribuam, remixem, adaptem e criem a partir do seu trabalho, mesmo para fins comerciais, desde que lhe atribuam o devido crédito pela criação original. É a licença mais flexivel de todas as licenças disponiveis. É recomendada para maximizar a disseminação e uso dos materiais licenciados. 
Ministério da Educação Universidade Tecnológica Federal do Paraná Câmpus Pato Branco

\section{UTrPR}

RENATA APARECIDA FERREIRA RIBAS

\section{AS MULTIFACES DE CHICA DA SILVA EM TRÊS ROMANCES BRASILEIROS}

Trabalho de pesquisa de mestrado apresentado como requisito para obtenção do título de Mestra Em Letras da Universidade Tecnológica Federal do Paraná (UTFPR). Área

de concentração: Linguagem, Cultura E Sociedade.

Data de aprovação: 24 de Fevereiro de 2021

Prof Mauricio Cesar Menon, - Universidade Tecnológica Federal do Paraná

Prof.a Marcia Maria De Medeiros, Doutorado - Universidade Estadual de Mato Grosso do Sul (Uems)

Prof Marcos Hidemi De Lima, Doutorado - Universidade Tecnológica Federal do Paraná

Documento gerado pelo Sistema Acadêmico da UTFPR a partir dos dados da Ata de Defesa em 24/02/2021. 
Dedico este trabalho ao meu esposo Andrey e a minha filha Alana Beatriz, por serem minha dose de incentivo diário nessa complexa jornada. 


\section{AGRADECIMENTOS}

Primeiramente a Deus, por me permitir ter capacidade e discernimento para chegar até esta etapa da minha vida.

Ao meu esposo Andrey, que ofereceu todo o suporte e incentivo para que eu pudesse desenvolver este projeto.

À minha filha Alana Beatriz, por ser meu porto seguro e tornar meus dias mais alegres e desafiadores.

Ao professor Dr. Maurício César Menon por suas sábias orientações, companheirismo e dedicação, principalmente, por apresentar essa temática e acreditar em meu potencial para o desenvolvimento desta pesquisa, e pelas contribuições a minha formação acadêmica.

Ao professor Dr. Marcos Hidemi de Lima, pelas aulas e contribuições ao meu trabalho e a minha formação.

À professora Dra. Márcia Maria de Medeiros, pelas preciosas contribuições que aprimoraram o meu trabalho e expandiram minha visão sobre a temática.

Aos meus colegas e professores do PPGL que contribuíram de alguma forma nessa jornada acadêmica.

A Coordenação de Aperfeiçoamento de Pessoal de Nível Superior - CAPES, pela bolsa que me foi concedida, a qual possibilitou o desenvolvimento da presente dissertação de mestrado. 
"A menos que modifiquemos a nossa maneira de pensar, não seremos capazes de resolver os problemas causados pela forma como nos acostumamos a ver o mundo".

Albert Einstein 
RIBAS, Renata Aparecida Ferreira. As multifaces de Chica da Silva em três romances brasileiros. 119 f. 2021. Dissertação (Mestrado em Letras) - Programa de Pós-graduação em Letras: Literatura, Sociedade e Interartes, Universidade Tecnológica Federal do Paraná, Pato Branco, 2021.

\section{RESUMO}

O presente trabalho tem como recorte de pesquisa três romances históricos brasileiros: Chica que Manda (1966), de Agripa Vasconcelos, Xica da Silva (1976), de João Felício dos Santos e Chica da Silva - Romance de uma vida (2016), de Joyce Ribeiro. O foco de análise será a construção da personagem Chica da Silva em cada romance, confrontando suas semelhanças e discrepâncias. $\mathrm{Na}$ personagem de Agripa Vasconcelos, Chica é descrita como uma figura sádica, por contentar-se maltratando escravos e mulheres que a façam sentir-se ameaçada em sua relação amorosa com o contratador João Fernandes. Já na obra de João Felício dos Santos, Chica aparece mais como uma mulher sedutora, configurando a figura da feme fatale. Enquanto que no romance de Joyce Ribeiro, configura-se como uma esposa zelosa e mãe amorosa, uma mulher de vida sofrida, que conseguiu encontrar a felicidade durante o período histórico da escravidão. Partindo desse pressuposto, a pesquisa se propõe em dividir-se em três diferentes momentos, no primeiro será feito um levantamento histórico do papel da mulher negra na sociedade da época e da pessoa de Francisca, estabelecendo como a figura feminina afrodescendente e ex-escrava era vista socialmente. Assim, serão usados estudiosos como Gilberto Freyre, Mary Del Priore e Emília Viotti Costa. Em um segundo momento, será feito um levantamento teórico literário para entender a construção da personagem ficcional do romance histórico, por meio de teóricos que estudaram a personagem ficcional, como Salvatore D'onofrio, Antonio Candido e Beth Brait e com teóricos do romance histórico, como Gyorgy Lukács e Antônio R. Esteves. Em um último momento, serão feitas as análises de cada romance separadamente, com enfoque na construção da personagem que retrata a pessoa de Chica da Silva. E por fim, serão feitas análises comparativas entre o que foi levantado tanto nas obras ficcionais, quanto nas obras de cunho histórico, a fim de revelar os possíveis elementos textuais e extratextuais que estabelecem diálogo com os escritos no momento de suas produções.

Palavras-chave: Chica da Silva; Romance Histórico; Personagem Ficcional. 
RIBAS, Renata Aparecida Ferreira. The multifaces of Chica da Silva in tree brazilian novels. 119 f. 2021. Dissertation (Master's degree in Linguistics and Literature studies) - Postgraduate Studies in Linguistics and Literature: Literature, Society and Interarts, Federal Technological University of Paraná, Pato Branco, 2021.

\begin{abstract}
The present work has as a research clipping three Brazilian historical novels: Chica que Manda (1966), by Agripa Vasconcelos, Xica da Silva (1976), by João Felício dos Santos and Chica da Silva - Romance de uma vida (2016), by Joyce Ribeiro. The focus of analysis will be the construction of the character of each novel, confronting your similarities and discrepancies. In the character of Agripa Vasconcelos, Chica is described as a figure sadist, for being content with mistreating slaves and women who make her feel threatened in her love relationship with contractor João Fernandez. Already in the character of João Felício dos Santos, Chica appears more as a seductive woman, setting the figure of feme fatale. While in Joyce Ribeiro's novel, she is configured as a zealous wife and loving mother, a woman of suffering life, who managed to find happiness during the historical period of slavery. Based on this assumption, the research proposes to divide in three different moments, in the first one will be done a historical survey of the role of black women in the society of the time and of Francisca's person, establishing how the female figure of African descent and ex-slave was socially seen. Thus, will be used bookishs as Gilberto Freyre, Mary Del Priore and Emília Viotti Costa. In a second step, will be done a theoretical literary survey to understand the construction of the fictional character of the historical novel through fictional character theorists, as Salvatore D'onofrio, Antonio Candido and Beth Brait and with theorists of historical romance, such as Gyorgy Lukács and Antônio R. Esteves. In a last moment, Will be done the analyzes of each novel separately, focusing on the construction of the character what portrays the historical person of Chica da Silva. And finally, comparative analyzes will be made between what was raised both in fictional works, as in historical works, in order to reveal the possible textual and extratextual elements that establish dialogue with the writings at the time of their productions.
\end{abstract}

Keywords: Chica da Silva; Historical novel; Fictional Character. 


\section{SUMÁRIO}

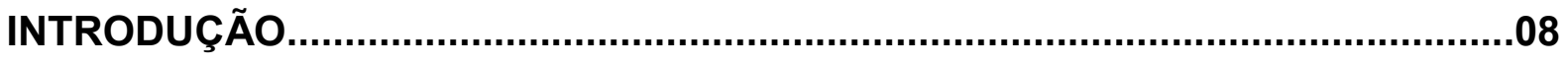

1 A ESFERA CULTURAL DO BRASIL COLÔNIA NO SÉCULO XVIII....................13

1.1. A FIGURA FEMININA NO PERÍODO COLONIAL ................................21

1.2. A FIGURA EMBLEMÁTICA DE CHICA DA SILVA .................................29

2 O SURGIMENTO DO ROMANCE HISTÓRICO TRADICIONAL...........................38

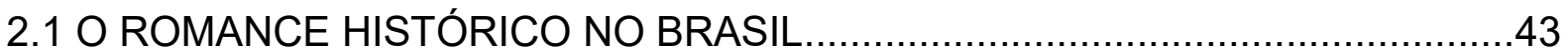

2.2 CONSIDERAÇÕES SOBRE O ROMANCE HISTÓRICO ...............................50

2.3 A IMPORTÂNCIA DOS ESTUDOS COMPARATIVOS EM ROMANCES

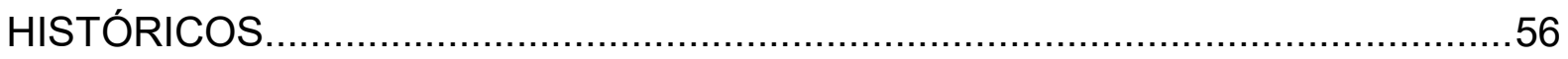

3 ASPECTOS CONSTRUCIONAIS DA PERSONAGEM FICCIONAL...................65

3.1 CHICA QUE MANDA, DE AGRIPA VASCONCELOS (1966)..........................70

3.2 XICA DA SILVA, DE JOÃO FELÍCIO DOS SANTOS (1976).............................85

3.3 CHICA DA SILVA: ROMANCE DE UMA VIDA, DE JOYCE RIBEIRO (2016)....98

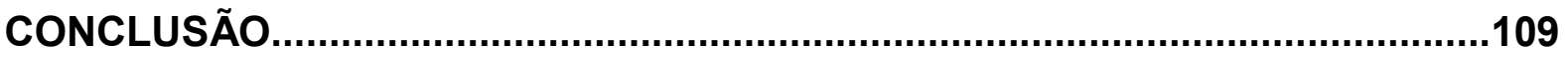

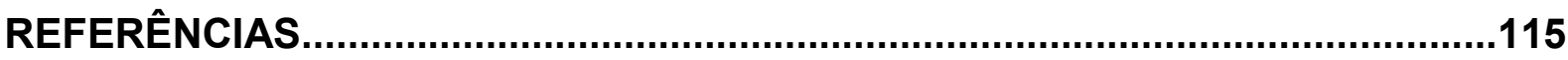




\section{INTRODUÇÃO}

A literatura e a história são disciplinas que fixam seu conteúdo por meio da linguagem e usam o passado como meio para produção de seus textos, especificamente na literatura, o romance histórico. Porém, elas possuem finalidades distintas, a literatura busca ficcionalizar dados historiográficos, enquanto o papel da história é procurar interpretar os fatos por meio de métodos de caráter cientifico. Sobre essas questões Hyden White informa que:

[...] a saber, que a "história" que é o tema de todo esse aprendizado só é acessível por meio da linguagem; que nossa experiência da história é indissociável de nosso discurso sobre ela; que esse discurso tem que ser escrito antes de poder ser digerido como "história"; e que essa experiência, por conseguinte, pode ser tão vária quanto os diferentes tipos de discurso com que nos deparamos na própria história da escrita (1991, p. 21).

Assim, entende-se que a história interpreta fatos passados, e por meio da literatura, aumentam-se os questionamentos sobre a pluralidade de discursos possíveis sobre o mesmo objeto histórico, seja um acontecimento ou pessoa, indagando a veracidade do discurso proposto pela história oficial. Exemplo disso é a figura de Francisca da Silva, pois a história que constrói a sua biografia pode ser questionada, uma vez que, por meio dos materiais disponíveis é possível apenas supor determinadas questões. Dessa maneira, observamos a existência de trabalhos de cunho literário e especificamente de cunho histórico sobre Francisca da Silva que divergem em algumas informações, como as obras de Joaquim Felício dos Santos e Júnia Furtano, as quais, por meio de métodos distintos, apresentam interpretações diferentes acerca da história de Francisca:

Essa caracterização do discurso histórico não quer dizer que os eventos, as pessoas, as instituições e os processos do passado jamais existiram realmente. Ela não quer dizer que não podemos ter informações mais ou menos precisas sobre essas entidades do passado. E ela não significa que não podemos transformar essas informações em conhecimento pela aplicação dos vários métodos desenvolvidos pelas diferentes disciplinas que constituem a "ciência" de uma época ou de uma cultura. Ela pretende, sim, enfatizar o fato de que a informação sobre o passado não é em si mesma especificamente histórica, da mesma forma como o conhecimento baseado nesse tipo de informação tampouco é em si mesmo especificamente histórico. Essa informação poderia ser melhor chamada de "arquivística", na medida em que pode servir como objeto de qualquer disciplina simplesmente ao ser tomada como 
assunto das práticas discursivas distintas dessa disciplina. Assim também, é apenas ao serem transformados em assunto do discurso histórico que nossa informação e nosso conhecimento sobre o passado podem ser considerados "históricos (WHITE, 1991, p. 22).

O tema da pluralidade de vozes acerca de um mesmo fato ou pessoa histórica torna-se uma questão importante a ser estudado tanto pelo campo de estudos literários como pelo campo de estudos da história. Assim, Paulo Astor Soethe enfatiza sobre "(...) a importância de prestar atenção à diversidade de versões, perspectivas, pontos de vista diferentes na figuração de acontecimentos históricos pela arte, e em especial pela literatura" (2009, p.162).

Dessa maneira, esta pesquisa objetiva realizar uma análise comparativa dos personagens ficcionais que retratam a figura histórica de Chica da Silva nos romances Chica que Manda (1966), de Agripa Vasconcelos, Xíca da Silva (1976), de João Felício dos Santos e Chica da Silva - O romance de uma vida (2016), de Joyce Ribeiro. Entretanto, ressalta-se a existência de outros romances históricos que trabalham com a mesma temática, porém, devido à necessidade de recorte do material de pesquisa, optou-se pelo uso dos três romances citados anteriormente. Justifica-se a escolha, pelo motivo das diferenças nos anos de publicação, pois a narrativa de Agripa Vasconcelos é a primeira a ser publicada, enquanto a de Joyce Ribeiro é a mais recente, e a obra de João Felício dos Santos é publicada dez anos depois da primeira narrativa sobre Chica, ademais, a narrativa de Santos é escolhida por ser a obra mais conhecida, pois o escritor, em um caso incomum, escreveu o roteiro de um filme ${ }^{1}$ e posteriormente esse tornou-se inspiração para a composição de sua obra.

Desse modo, o foco da pesquisa será a construção da personagem de cada romance, analisando suas similaridades e diferenças. Na primeira obra publicada sobre Chica, ela é descrita como uma personagem complexa, pois ora é boa e caridosa, ora é perversa e sádica, pois sente-se contente ao cometer crueldades contra seus escravos e contra mulheres que a façam se sentir ameaçada em sua relação amorosa com o contratador João Fernandes de Oliveira.

Já a Chica da Silva de João Felício dos Santos é construída sobre o estereótipo sexual da mulher negra, ademais são realçados nela traços que remetem ao sadismo sexual. A última personagem, presente no romance de Joyce

\footnotetext{
${ }^{1}$ O filme brasileiro Xíca da Silva (1976), dirigido por Carlos Diegues.
} 
Ribeiro, configura-se de maneira oposta às outras, sendo descrita como uma mulher de vida sofrida por conta da escravidão, ao mesmo tempo que representa um símbolo de ascensão e esperança para as mulheres de mesma condição social, pois, por meio do casamento com o contratador João Fernandes de Oliveira, consegue encontrar a felicidade em um período conturbado e, assim, torna-se uma esposa zelosa e mãe amorosa.

Dessa maneira, a pesquisa se propõe em dividir-se em três diferentes momentos, em que cada um representa um objetivo especifico do trabalho. No primeiro será feito um levantamento histórico da esfera cultural e do papel da mulher negra na sociedade da época e da pessoa de Francisca, estabelecendo como a mulher negra e ex-escrava era vista socialmente.

Em um segundo, será feito um levantamento teórico literário do romance histórico buscando traçar um panorama do desenvolvimento do gênero no Brasil, para entender a construção da personagem ficcional do romance histórico, cujo gênero literário trabalha com a ficcionalização de dados históricos. Neste mesmo momento, será feito o levantamento teórico da literatura comparada, a fim de mobilizar as teorias necessárias para a análise comparativa e enfatizar a importância dos estudos comparativos nesse gênero.

Por fim, serão feitas, primeiramente, as análises das obras, separadamente, com enfoque na construção das diferentes figuras que retratam Chica da Silva. Posteriormente, serão feitas as análises comparativas entre o que foi levantado tanto nas obras ficcionais, quanto nas obras de cunho histórico, com o objetivo de revelar os possíveis elementos textuais e extratextuais que estabelecem diálogo com os escritos no momento de suas produções e quais elementos entre as obras ficcionais se assemelham e divergem entre si.

Para a primeira parte do trabalho foram necessárias para entender o período colonial e o papel da mulher na sociedade as seguintes obras: Casa-grande \& senzala, de Gilberto Freyre, Da Monarquia à República, de Emília Viotti Costa, História das Mulheres no Brasil, de Mary Del Priore, A Permanência do Círculo, de Roberto Reis e o volume I de História da Vida Privada no Brasil, organizado por Laura de Mello e Souza. Em relação a quem foi a pessoa de Francisca da Silva foram utilizados os estudos históricos de caráter biográfico Chica da Silva e o 
contratador de diamantes, de Júnia Ferreira Furtano, que faz uma biografia dos passos dela em seu período de vivência.

Para o segundo momento, relativo ao entendimento do que é o romance histórico e as especificidades do gênero no Brasil, foram estudadas as obras $O$ romance histórico, de Gyorgy Lukács, e O Romance Histórico Brasileiro Contemporâneo (1975-2000), de Antônio R. Esteves além de textos de Marilene Weinhardt sobre a temática.

Ademais, como a pesquisa se propõe a realizar uma análise comparativa entre os três romances, foi feita nesse momento uma breve introdução aos estudos de literatura comparada e sua importância para os estudos de romances históricos com um elemento histórico em comum. Para isso, foram usados os livros Literatura Comparada, de Paulo Astor Soethe, Literatura Comparada, de Tânia Franco Carvalhal e Literatura Comparada: história, teoria e critíca, de Sandra Nitrini.

Para o último o momento, foi feita uma apresentação da construção da personagem ficcional, por meio das obras $A$ Personagem, de Beth Brait, $A$ personagem de ficção, de Antonio Candido, Pessoas do livro - Estudos sobre a personage, de Carlos Reis. Também foram estudados os textos $A$ personagem de fiç̧ão de Salvatore D'onofrio e O conceito de personagem na fiç̧ão, de William $\mathrm{H}$. Gass.

Essas obras também auxiliaram na realização da análise da construção da personagem ficcional que, nesse caso, foram as protagonistas de cada romance que são inspiradas na pessoa histórica de Francisca da Silva. As análises foram feitas de forma individual e, ao fim, realizou-se a análise comparativa entre elas como forma de apontar suas semelhanças e discrepâncias. Além das obras citadas, utilizou-se artigos, dissertações e teses que abrangiam as áreas em questão.

A pesquisa realizada foi forjada por meio do método bibliográfico de ordem qualitativa, isto é, "(...) a pesquisa bibliográfica é desenvolvida com base em material já elaborado, constituído principalmente de livros e artigos científicos" (GIL, 2002, p. 44). A pesquisa que aqui se propõe enquadra-se no conceito de bibliográfica, pois para seu desenvolvimento, realizou-se a leitura e estudo de livros, artigos e dissertações sobre o tema da pesquisa. Ademais, enfatiza-se a sua ordem qualitativa: 
Dessa forma, Marconi e Lakatos (2010) explicam que a abordagem qualitativa se trata de uma pesquisa que tem como premissa, analisar e interpretar aspectos mais profundos, descrevendo a complexidade do comportamento humano e ainda fornecendo análises mais detalhadas sobre as investigações, atitudes e tendências de comportamento. Assim, o que percebemos é que a ênfase da pesquisa qualitativa é nos processos e nos significados. (ARAÚJO, 2013, p.03).

Desse modo, percebe-se, que a personagem parte da existência de uma pessoa histórica, porém, quando ficcionalizada, torna-se algo novo, deixando de ser um reflexo da realidade, tornando-se uma personagem inovada, com vida própria, uma representação da experiência de alguém com o passado. Assim, algo histórico, seja pessoa ou fato, pode ser interpretado sob diversas perspectivas e formas representativas, pois são visões de sujeitos de diferentes períodos e ideais. 


\section{A ESFERA CULTURAL DO BRASIL COLÔNIA NO SÉCULO XVIII}

O processo de colonização do Brasil, em seu primeiro momento, teve intenção exploratória, não possuindo interesses explícitos de estabelecer permanência no território. Entretanto, as práticas de vivência dos colonos marcaram as primeiras relações sociais e o início da formação das famílias brasileiras. Para Fernando Novais (1997), um destaque importante para a constituição social nacional foi a diversidade, pois aqui se encontravam os colonizadores europeus, os nativos (índios) e os negros escravizados (africanos), resultando em uma constituição populacional miscigenada, que se refletiu na composição cultural do país:

Para compormos ainda mais explicitamente esse quadro é preciso agregar-lhe outra característica, que, aliás, vai na mesma direção: refiro-me à necessária diversidade das populações na Colônia. Por definição, as gentes na Colônia se dividem entre os colonizadores e os nativos: mas na colonização do Antigo Regime, nas áreas em que a compulsão do trabalho foi levada ao limite da escravidão, essa diversidade se acentuou com o tráfico negreiro, que carreou para o Novo Mundo os contingentes africanos. Se nos lembrarmos de que tanto ameríndios como africanos tinham também grande diversidade interna, começaremos a entender a complexidade do melting-pot colonial. $E$ do convívio e das inter-relações desse caos foi emergindo, no cotidiano, essa categoria de colonos que, depois, foi se descobrindo como "brasileiros" (NOVAIS, 1997, p. 22-23).

O autor explana sobre como ocorreu no Brasil o melting-pot, que na tradução literal quer dizer "caldeirão". Esse contexto se expressa como o encontro e a mistura de diferentes etnias e raças, constituindo os eixos da identidade brasileira, que se caracterizam por traços culturais tanto portugueses, como indígenas e africanos. Inicialmente, os colonizadores, por necessidade, precisaram adotar algumas técnicas indígenas para garantir sua sobrevivência, como Leila Mezan Algranti apresenta:

Grande parte dos costumes domésticos dos colonos portugueses teve que se moldar à realidade dos trópicos. Sérgio Buarque de Holanda - entre outros autores - escreveu algumas páginas memoráveis sobre a influência dos índios nas técnicas e nas soluções adotadas pelos primeiros habitantes de São Paulo em quase todas as atividades necessárias à sobrevivência (1997, p.119).

Posteriormente, com os homens e mulheres negros escravizados e trazidos a força de África, a constituição cultural é enriquecida novamente, pois algumas 
funções são impostas a eles, como as atividades domésticas e cuidados com os filhos de seus senhores destinados as mulheres negras escravizadas. Dessa forma, de acordo com Gilberto Freyre:

Na ternura, na mímica excessiva, no catolicismo em que se deliciam nossos sentidos, na música, no andar, na fala, no canto de ninar menino pequeno, em tudo que é expressão sincera de vida. Trazemos quase todos a marca da influência negra. Da escrava ou sinhama que nos embalou. Que nos deu de mamar. Que nos deu de comer, ela própria amolengando na mão o bolão de comida. Da negra velha que nos contou as primeiras histórias de bicho e de malassombrado. Da mulata que nos tirou o primeiro bicho-de-pé de uma coceira tão boa. Da que nos iniciou no amor físico e nos transmitiu, no ranger da cama-de-vento, a primeira sensação completa de homem. Do moleque que foi o nosso primeiro companheiro de brinquedo (FREYRE, 2003, p. 367).

Gilberto Freyre, no trecho acima, aponta como as relações entre portugueses e africanos escravizados eram de proximidade física. O escritor endossa seu discurso a respeito do convívio entre brancos e negros, como se houvesse igualdade entre as duas raças. Porém, é consenso entre historiadores que essas relações eram marcadas por ideais de superioridade e de inferioridade, com violência e interesse exploratório, para o trabalho físico e finalidades sexuais. "A norma consistia na exploração da africana pelo senhor escravocrata, e este fato ilustra um dos aspectos mais repugnantes do lascivo, indolente e ganancioso caráter da classe dirigente portuguesa" (NASCIMENTO, 2016, p. 73). Ademais, essa relação na época era vista publicamente como positiva, pois a elite via o resultado dela, a mestiçagem, como um triunfo civilizatório.

Aqueles nascidos de uniões entre pessoas de cor parda e negra são classificados como brancos; e através de reclassificações o grupo negro perde grande quantidade e ganha muito pouco, o grupo pardo ganha muito mais do que perde, e o grupo branco ganha muito e não perde nada (MORTARA, apud NASCIMENTO, 2016, p. 90).

Desse modo, quando os mestiços eram classificados e associados à branquitude, acabava-se enfraquecendo o quantitativo negro. Para Emília Viotti da Costa (1999), a escravidão foi um processo exploratório e cruel do sujeito africano na sociedade brasileira, o qual Gilberto Freire busca descrever como algo necessário para a constituição brasileira. Portanto, sugere-se que essas observações são feitas do ponto de vista do proprietário de escravos. Ademais, o 
sujeito escravizado era visto como propriedade nesse período, assim, as leis da Coroa e da Igreja asseguravam apenas os direitos dos proprietários, e dessa forma eles possuíam autonomia sobre os homens e mulheres negros. Isso é reforçado quando vemos as cenas de abandono e penúria da população negra perante a liberdade da pós-abolição:

Depois de sete anos de trabalho, o velho, o doente, o aleijado e um mutilado - aqueles que sobreviveram aos horrores da escravidão e não podiam continuar mantendo satisfatória capacidade produtiva - eram atirados na rua à própria sorte qual lixo humano indesejável; estes eram chamados de "africanos livres". Não passava, a liberdade sob tais condições, de pura e simples forma de legalizado assassínio coletivo. As classes dirigentes e autoridades públicas praticavam a libertação dos escravos idosos, dos inválidos e dos enfermos incuráveis, sem conceder qualquer recurso, apoio, ou meio de subsistência. Em 1888, se repetiria o mesmo ato "Libertador" que a história do Brasil registra com o nome de Abolição ou de Lei Áurea, aquilo que não passou de um assassinato em massa, ou seja, a multiplicação do crime, em menor escala, dos "africanos livres" (NASCIMENTO, 2016, p. 79).

Assim, percebemos que Nascimento revela aspectos que contrariam a ideia do mito da democracia racial, pois ele descreve os contornos de violência, opressão, discriminação e preconceitos que versões da história brasileira tentaram esconder sobre a sociedade escravagista.

Roberto Reis salienta que a sociedade escravagista era constituída por um estreito círculo social, cujo núcleo era formado pelo patriarca da família, ou seja, o senhor. Ao seu redor há círculos concêntricos direcionados ao centro do sistema, constituídos por esposa e filhos, agregados, sustentados pela escravidão, formando a nebulosa, composta por sujeitos sociais que sofrem total influência do poder do patriarca. Portanto, "Existe um núcleo central organizado, cuja coerência é dada pelo sistema escravocrata; e em torno deste núcleo, disposta mesmo em seus interstícios e sofrendo sua influência, uma nebulosa social incoerente e desconexa" (REIS, 1987, p.31). Todos socialmente seriam afetados por esse núcleo e constituiriam a nebulosa, "ao figurar tal organização como uma série de círculos sociais homogêneos, orientados para o centro. Quanto mais próximo do centro, mais elevada tendia a ser a posição social do indivíduo" (idem, p. 26). 
Entretanto, ressalta-se que durante o século XVIII já se apresentavam distintas constituições familiares, como vemos:

É o espaço do domicílio que reúne, assim, em certos casos, apenas pessoas de uma mesma família nuclear e um ou dois escravos; em outros, somavam-se a essa composição agregados e parentes próximos, como mães viúvas ou irmãs solteiras. Por vezes encontramos domicílios compostos de padres com suas escravas, concubinas e afilhadas, ou então comerciantes solteiros com seus caixeiros. Em alguns domicílios verificamos a presença de mulheres com seus filhos, porém sem maridos; também nos deparamos com situações em que um casal de cônjuges e a concubina do marido viviam sob o mesmo teto. Isso sem falar nos filhos naturais e ilegítimos que muitas vezes eram criados com os legítimos. Tantas foram as formas que a família colonial assumiu, que a historiografia recente tem explorado em detalhe suas origens e o caráter das uniões, enfatizando-Ihe a multiplicidade e especificidades em função das características regionais da colonização e da estratificação social dos indivíduos (ALGRANTI, 1997, p. 86-87).

Leila Mezan Algranti (1997) nos mostra modos diferentes de composição da família patriarcal, apesar da diferença entre membros que a moldavam. Reis (1987) salienta que o centro estava figurado por um homem, pois a mulher não era vista na época com igualdade, sendo inferiorizada em relação ao elemento masculino. Assim, na esfera cultural da sociedade patriarcal, os homens tinham liberdade total e autoridade sobre as mulheres, ditando como deviam se comportar e agir em sociedade.

As mulheres eram violadas em seus direitos de existir enquanto ser humano pelos homens, começando pelo pai e depois pelo marido, pois "Era ele, o marido, quem também tratava dos interesses da mulher e administrava, no caso, a herança que the coubera em consequência da morte do pai, comprava-Ihe vestidos, jóias e os "trastes" da casa, como se dizia na época" (ALGRANTI, 1997, p.138). Eram vistas como aquelas que viviam à sombra masculina, frágeis e incapazes, pois, no século $X V I I I$, figuravam num papel que thes era imposto, sendo romantizadas, eram reprimidas e deveriam se portar como devidas donzelas. Portanto, "reproduziam nas instituições de reclusão feminina os costumes domésticos e as práticas de sociabilidade feminina próprias ao mundo exterior (ALGRANTI, 1997, p.138).

As diferenças entre o sexo masculino e o feminino eram nitidamente marcadas no século XVIII, principalmente quando se tratava da criação dos filhos. Como Del Priore aponta: 
$\mathrm{Na}$ intimidade, a preocupação com o crescimento dos filhos era recorrente. Testamentos feitos entre os séculos XVII e XVIII registram instantâneos de como se concebia a criação da prole: aos machos devia se ensinar a ler, escrever e contar. Às femeas, coser, lavar e os bons costumes; ambos deviam sempre "apartar-se do mal e chegar-se ao bem" (1997, p.311).

Sendo assim, havia parâmetros sociais em que os homens eram diferenciados desde a criação. O menino era direcionado a atividades intelectuais, para torná-lo apto a assumir negócios de família ou posições importantes socialmente. Já a menina era orientada a atividades do lar e a se portar dentro do que eram considerados bons costumes a serem seguidos pelas mulheres.

Nesse período os homens possuíam um status de poder que lhe era praticamente ilimitado, assim, o homem tinha total liberdade em seus atos, se relacionando com mulheres indígenas e negras ao mesmo tempo em que estava casado, não sendo tais atitudes passiveis de punição. Ao contrário, na maioria das vezes, sua esposa se via na tarefa de criar seus filhos e os filhos ilegítimos do marido, que eram frutos de traição, pois "as índias e negras deram-lhes muitos filhos bastardos, e as mulheres brancas, que foram aumentando paulatinamente em número, acabaram eleitas para o matrimônio (ALGRANTI, 1997, p.137). Além de que, por conta do sistema patriarcal, as mulheres eram divididas em dois grupos: brancas, para casar, e mulheres indígenas e negras, para fins sexuais. "Provavelmente radica-se, nesse padrão de relações, a origem do velho ditado: "branca pra casar, mulata pra foder, negra pra trabalhar", palavrório recorrente entre os homens daquele tempo" (MOTT, 1997, p.240). Aliás:

Ao ímpeto lusitano as índias teriam correspondido plenamente, acrescenta Freyre, e talvez o tenham feito menos por razões priápicas, como alguns disseram, do que pela "circunstância da escassez, quando não da falta absoluta, de mulher branca". E ao encontro com as índias ter-se-ia seguido o enlace com as negras, depois com as mulatas, e assim se formaria o povo brasileiro, compensando-se a precariedade da vida no trópico, a alimentação deficiente, as doenças e tudo o mais, pelo adocicamento das relações entre as diferentes culturas (MOTT, 1997, p. 229).

Apesar da promiscuidade que rodeava as relações sexuais masculinas, foram elas que fundiram as raças que se encontravam no território, originando um povo 
miscigenado. Essas relações, contudo, na maioria das vezes, eram resultados da superioridade masculina, como vemos:

Não resta dúvida de que tal encontro implicou relações de poder que não excluíam a violência física e, no limite, o estupro. O próprio Freyre acaba por reconhecê-lo, à sua moda, ao dizer que "uma espécie de sadismo do branco e de masoquismo da índia ou da negra terá predominado nas relações sexuais como nas sociais do europeu com as mulheres das raças submetidas ao seu domínio (MOTT, 1997, p. 230).

Como Luiz Mott afirma, as relações sociais que marcaram o período colonial no Brasil e envolviam mulheres negras escravizadas tiveram como marca a violência seja física ou simbólica. Exemplo disso pode ser percebido no fato de que muitas dessas mulheres aceitavam sujeitar-se sexualmente aos seus senhores para não sofrem outros abusos, como serem punidas no tronco.

As mulheres eram divididas, segundo os interesses masculinos, em brancas, destinadas ao casamento, e negras para fins sexuais; porém, Leila Algranti (1997) aponta alguns aspectos, como a falta de mulheres brancas, a presença da escravidão e a constante expansão do território levaram a transformações de práticas e de costumes do colono, como a hospitalidade com os visitantes e os alimentos que degustavam em suas refeições. O casamento, porém, era permitido apenas com mulheres brancas, ainda assim desde que compatível com classe social do homem:

Rival e cúmplice do casamento a um só tempo - e por vezes enlaçado com o estado clerical - o concubinato moldava as relações extraconjugais da Colônia, relações em boa medida pluriétnicas, não sendo comum naquele tempo a ocorrência de casamentos entre nubentes de posições sociais díspares. Casavamse todos "dentro da mesma igualha", ou quase, como que a seguir o conselho dos moralistas, ao menos quanto à cor e à fortuna, deixando os amores e deleites para o mundo dos "tratos ilícitos" (MOTT, 1997, p. 238).

Assim, os homens possuíam interesses em unir-se com mulheres negras ou indígenas, mas sem a possibilidade do casamento formal perante a entidade religiosa, surge o concubinato, "fruto dos amores entre os senhores ou homens livres brancos e suas escravas ou forras negras. É claro que o concubinato extravasou - e muito - da esfera do sexo pluriétnico ou das relações entre livres e escravos acentuadas até aqui" (MOTT, 1997, p. 234), pois essas relações eram 
marcadas pelas esferas do poder masculino sobre o sujeito feminino, que se via envolvido por uma possibilidade um pouco melhor de sobrevivência no mundo patriarcal.

O concubinato poderia ocorrer de formas diferentes. Os homens mais bemsucedidos, ou seja, aqueles que possuíam cargos públicos e estavam diretamente ligados à Coroa portuguesa possuíam o livre arbitro na escolha da mulher a se tornar sua esposa, assim, por meio do concubinato, muito embora não houvesse a legalidade civil ou religiosa, a escolhida tornava-se responsável por tarefas igualitárias as que seriam destinadas socialmente através do casamento, às mulheres brancas, como cuidar do lar, dos criados domésticos e dos filhos. Mesmo que alguns concubinatos não fossem assumidos publicamente, as pessoas ficavam sabendo sobre as relações quando elas ocorriam, porém, "havendo casos em que humildes donos de uma só escrava mantinham com ela amancebamento e visando, por vezes, a aumentar suas rendas, colocavam-na na prostituição" (MOTT, 1997, p. 234).

As visões morais da época também julgavam o concubinato como algo terrível. "A maioria da população vivia em concubinato ou em relações consensuais, apesar de a Igreja punir os recalcitrantes com admoestações, censuras, excomunhões e prisões" (DEL PRIORE, 1997, p.312), porém cada vez mais essa prática conseguiu adeptos, na maioria das vezes, resultando em filhos, ou seja, em constituição de famílias.

Após entendermos a composição da típica família colonial, pensamos a respeito da convivência doméstica e com as demais famílias da colônia. A vida social era extremamente restrita, não se comparando com o que os colonos estavam acostumados em Portugal. A distância geográfica, inicialmente, dificultou em muito a interação social, porém a igreja foi um espaço que aproximou as pessoas e fez a interação social acontecer na colônia:

No mundo americano, durante os primeiros séculos de colonização, o espaço de sociabilidade, para a maior parte da população, se concentrava fora das paredes do domicílio, fosse ele a rua ou a igreja, uma vez que os grandes momentos de interação social eram as festas religiosas comemoradas com procissões, missas e tedéuns (ALGRANTI, 1997, p. 113). 
A interação social ocorria, na maior parte das vezes, no exterior da casa, frequentemente na igreja e em eventos religiosos, pois era o único espaço facilitador de encontro com moradores vizinhos. Assim, "sendo a igreja o espaço por excelência das sociabilidades, do encontro dominical das famílias, das festas religiosas. Era ali, em meio às missas e ofícios divinos, que se iniciavam muitos flertes e namoros, quando não adultérios" (MOTT, 1997, p. 258).

A igreja era considerada um espaço sagrado, porém isso não a impediu de ser um lugar onde ocorriam algumas promiscuidades. Alguns relatos apontam para casais de amantes que se encontravam nesse espaço e consumavam a traição por meio de encontros sexuais que ocorriam no interior do átrio paroquial. Tais fatos jamais escaparam do "radar" social, pois o que ocorria com as pessoas da colônia era de conhecimento geral. Desse modo, "os aristocratas da América portuguesa desprezavam os templos e espaços religiosos públicos, sobretudo pelas tentações que podiam representar à pureza e honestidade das mulheres das famílias de respeito" (MOTT, 1997, p.161). Portanto, muitos pais e parentes não autorizavam que suas filhas saíssem de casa, nem para a missa, ou outros fins e, quando isso acontecia, as mulheres deveriam estar acompanhadas por alguém da família do sexo masculino:

Como sabiamente salientou Durkheim no clássico Formas
elementares da vida religiosa, as cerimônias e os rituais públicos
sempre tiveram uma função catalisadora do etos comunitário,
funcionando igualmente como eficiente mecanismo de controle social
e manutenção da rígida hierarquia da igreja militante. Assim, a missa
obrigatória aos domingos e dias santos de guarda - um total de 98
feriados! -, a obrigação da desobriga pascal (atestado assinado
pelo vigário que o freguês confessou-se e comungou ao menos uma
vez por ocasião da Páscoa da Ressurreição), a indispensabilidade da
frequência aos sacramentos, são algumas das práticas religiosas
amalgamadoras do corpo místico no Brasil de antanho, um
contrapeso socializador significativo para compensar a dispersão
espacial e isolamento social dos colonos na imensidão da América
portuguesa (MOTT, 1997, p.159).

A Igreja se constitui, pois, neste período, em um espaço de interação social fora do âmbito privado. Constitui-se também em um locus de poder que exerce o controle sobre as pessoas, norteando seu modo de agir, definindo padrões de comportamento e regras de convivência, já que ela instituía uma série de obrigações que deveriam ser seguidas pelos fiéis. "Tão interessada estava a Santa Madre Igreja 
no controle ao menos anual de seus fregueses, que o pároco era obrigado a fazer o Rol dos Confessados" (MOTT, 1997, p. 211). Desse modo, os párocos deviam fazer uma lista com dados dos fiéis, como nome, sobrenome, endereço, por exemplo. Isso tudo para convocá-los para a obrigação pascal da desobriga, que consistia em uma confissão que permitia ao ou à fiel participar da celebração da Páscoa. Aqueles e aquelas que não cumpriam tal obrigação, poderiam sofrer penas pecuniárias.

A intimidade dos sujeitos da colônia era conhecida principalmente pelas fontes de origem religiosa, pois era essa entidade que procurava instituir toda a moral social da época, direcionando o que seria certo ou errado em cada contexto. Exemplo disso é a vida sexual dos seus seguidores. "A própria Igreja, evidentemente, considerava a sexualidade matéria de sua alçada, elevando à categoria do sagrado o sexo conjugal voltado para a procriação e lançando tudo o mais no domínio diabólico ou mesmo herético" (MOTT, 1997, p. 246).

Dessa forma, muitas pessoas vizinhas e até mesmo os homens e mulheres negros escravizados, quando viam alguma postura desviante da preconizada pela igreja, procuravam seus representantes para denunciar. Inclusive, quando se tratava de sexualidade, o fato de algumas casas serem perto demais, permitia que se escutassem o prazer alheio: "até os gemidos de amantes ardorosos não raro podiam ser escutados por ouvidos indiscretos, sem contar os encontros amorosos" (MOTT, 1997 , p. 227). Segundo as leis instituídas religiosamente, o prazer sexual demonstrado por gemidos provinha de atitudes heréticas, pois o encontro físico devia ter fins apenas de procriação.

Com uma rotina movimentada, as famílias não possuíam muito tempo para interagir entre si. Desse modo, elas desenvolveram "o hábito de reunir a família ao menos uma vez por dia durante a refeição principal [...], dá-nos a impressão de um convívio familiar pelo menos entre os indivíduos de algumas posses" (ALGRANTI, 1997, p. 125). Esse momento era considerado privado, ou seja, algo mais familiar, sendo proibido fazer ou receber visitas nesse horário, com o intuito de preservar a intimidade entre os entes queridos. Apesar dos momentos de restrição de visitas, quando essas apareciam eram tratadas com a maior hospitalidade. "As grandes distâncias e o parco povoamento transformaram a hospitalidade numa característica e necessidade do mundo colonial brasileiro" (ALGRANTI, 1997, p. 93-94). 
As interações sociais durante o período colonial eram difíceis em virtude de uma série de elementos, entre eles a dimensão geográfica do território e a rotina da vida colonial, repleta de afazeres para os mais pobres e pleno de controle sobre os primeiros, pelos mais ricos, já que cabia aos senhores a fiscalização das atividades realizadas e a verificação em relação às mesmas estarem de acordo com a sua vontade. Quando ocorria, alguns costumes vindos de Portugal foram adaptados para a vida que se instaurava no novo território, o que é perceptível quando falamos sobre hospitalidade. Quando a interação social ocorria passou a ser permeada pelos valores trazidos pelos colonos portugueses que buscavam seguir as práticas advindas de seu modelo de civilização.

\subsection{A FIGURA FEMININA NO PERÍODO COLONIAL}

Submissão e recato eram características impostas e esperadas socialmente do sujeito feminino, que deveria viver à sombra de seu pai e, após o casamento, do seu marido. A mulher deveria seguir um determinado padrão de comportamento para ser vista como senhora digna e apta ao casamento e à maternidade. Para ocupar esse posto, devia ser branca, pois às mulheres negras cabiam outras obrigações, como a de amante:

As mulheres brancas, em pequeno número no acanhado litoral do século $\mathrm{XVI}$, teriam vivido em completa sujeição, primeiro aos pais, os todo-poderosos senhores de engenho, depois aos maridos. Teriam vivido, como escreveu Gilberto Freyre, num "isolamento árabe", idealizando uma estrutura de serralho à moda tropical, quer no tocante à submissão, quer às eventuais "solturas" de sinhás e sinhazinhas, todas invariavelmente punidas, em caso de falta grave, com o rigor da lei patriarcal (VAINFAS, 2004, p. 98).

A mulher branca era idealizada socialmente, apresentado determinadas características como obediência, não-erotização, conhecimento dos afazeres domésticos, essenciais para ser vista com bons olhos. Quando, porém, possuía algum comportamento desviante do padrão, era severamente punida, sendo mantida em cárcere em sua casa ou em conventos. A imagem que o período construiu em relação à mulher negra, no entanto, era completamente diferente: sua existência parecia resumir-se ao gozo dos senhores de engenho, sendo que eram rotuladas como mulheres fogosas. Ademais, sofriam duplamente com a violência, tanto por 
conta da dominação masculina impetrada sobre seus corpos, quanto pela violência que sofriam por parte das senhoras brancas, que as viam como uma ameaça, justamente pelo imaginário de volúpia criado em torno das mulheres negras escravizadas ou não. Sobre o assunto Vainfas informa que:

A mesma fama tinham as negras da Guiné, as crioulas, especialmente as da casa-grande, amantes de sinhôs e sinhozinhos. Essas eram também as vítimas prediletas de sinhás tirânicas que não hesitavam em supliciá-las por ciúme ou simples inveja "de seus belos dentes e rijos peitos". E a predominar sobre todas em matéria de paixão e ardor, lá estava a mulata, exemplo recorrente de beleza e sedução no imaginário masculino relacionado à terra brasílica. Muitos homens cantaram em prosa e verso as virtudes da mulata e a ela se vergaram, a começar pelo célebre Gregório de Matos, o Boca do Inferno da Bahia seiscentista (VAINFAS, 2004, p. 98).

As mulheres negras eram marcadas pelo estereótipo sexual, pois sua condição de pessoa escravizada as levava a submeterem-se às violências de caráter sexual para evitar sanções físicas. Mesmo as mulheres negras libertas sofriam com esta situação, pois no sistema social em que estavam inseridas eram também figuras à margem e, devido à escassez de opções de trabalho que pudessem executar, passavam a ver seu corpo como meio de subsistência, sendo cada vez mais inferiorizadas pela posição ocupada:

As prostitutas eram identificadas por apelidos nas comunidades em que habitavam Surgiam assim "Sopinha", "Cachoeira", "Rabada", "Pisca", "Comprimento", "Foguete", "A mãe do Mundo" e muitos outros. O estigma da prostituição agora aparecia acompanhado desses depreciativos que reforçavam a desclassificação social de mulheres negras, mulatas, carijós empurradas para aquela prática. (FIGUEIREDO, 2004, p.131)

A sexualidade feminina no Brasil colônia, seguindo a lógica herdada do catolicismo europeu medieval trazida de além-mar pelos colonizadores portugueses, era vigiada com constância pelas instituições que fortaleciam a ação do patriarcado. Conforme preconiza Araújo:

Das leis do Estado e da Igreja, com frequência bastante duras, à vigilância inquieta de pais, irmãos, tios, tutores, e à coerção informal, mas forte, de velhos costumes misóginos, tudo confluía para o mesmo objetivo: abafar a sexualidade feminina que, ao rebentar as amarras, ameaçava o equilíbrio doméstico, a segurança do grupo social e a própria ordem das instituições civis e eclesiásticas (ARAÚJO, 2004, p. 37). 
Como Araújo afirma, as mulheres eram privadas de sua sexualidade pelas maiores autoridades da época, pois acreditava-se que por meio dela as mulheres se tornariam ameaças ao controle exercido pelo sistema patriarcal que reinava e à superioridade masculina tão venerada. Esse fator relaciona-se com a construção identitária pejorativa em relação à mulher negra, pois ela se constituiu em figura que, em tese, descumpria esses protocolos seja por vontade própria ou quando era forçada a isso. Como forma de defender-se desse ataque, essas entidades a condenavam, reforçando os estereótipos sobre ela.

O medo era a arma que a autoridade masculina utilizava para definir algumas das suas explicações em relação ao sistema patriarcal. A Igreja utilizava do texto bíblico para reforçar a submissão feminina ao homem, como se percebe nesta passagem de Paulo (5:22-24): "As mulheres estejam sujeitas aos seus maridos como ao Senhor, porque o homem é a cabeça da mulher, como Cristo é a cabeça da Igreja... Como a Igreja está sujeita a Cristo, estejam às mulheres em tudo sujeitas aos seus maridos". O discurso religioso reafirmava que a submissão feminina era a vontade divina, e outro aspecto bíblico usado para reforçar essa ideia é a criação humana, uma vez que Deus teria feito primeiro Adão e, de sua costela, Eva. Portanto, a mulher deveria estar em uma posição inferior em relação ao do homem:

Quanto às mulheres, que elas tenham roupas decentes, se enfeitem com pudor e modéstia; nem tranças, nem objetos de ouro, pérolas ou vestuário suntuoso; mas que se ornem, ao contrário, com boas obras, como convém a mulheres que se professam piedosas. Durante a instrução, a mulher conserve o silêncio, com toda submissão. Eu não permito que a mulher ensine ou doutrine o homem. Que ela conserve, pois, o silêncio. Porque primeiro foi formado Adão, depois Eva. E não foi Adão que foi seduzido, mas a mulher que, seduzida, caiu em transgressão. Entretanto, ela será salva pela sua maternidade, desde que, com modéstia, permaneça na fé, no amor e na santidade (TIMÓTEO, 2: 9-15).

Ademais, conforme supracitado, a mulher era condenada por nascer mulher, pois carregava consigo o pecado original, devendo viver em obediência ao seu esposo e redimir-se pela maternidade, que a aproximava da imagem de Maria. Já as desviantes, que transgrediam as leis divinas e do homem, deveriam ser punidas. 
encarnava o emblema perigoso da desordem cósmica, da impureza feminina e da perturbação social. Fugia de qualquer controle, em suma. O que dizer, porém, da mulher normal? Ela também carregava o peso do pecado original e por isso, sobretudo sua sexualidade, devia ser vigiada muito de perto (ARAÚJO, 2004, p. 40).

Como Araújo enfatiza, a mulher considerada "anormal" para a sociedade transgredia todos os princípios morais da época, colocava o sistema em perigo e ameaçava o controle da Igreja, detentora do controle social. Assim, cabia ao poder patriarcal controlar essa mulher, domesticá-la e pô-la no lugar que havia sido predestinado a ela pelo próprio texto bíblico. O controle da situação era feito pela Igreja, que cuidava meticulosamente, por meio do confessionário, dos gestos, atos, sentimentos e sonhos dessas mulheres. É interessante pensar que quando elas se casavam, a pressão sobre sua sexualidade somente aumentava, devido ao encontro carnal com seus esposos:

Moderação, freio dos sentidos, controle da carne, era o que se esperava de ambos, pois o ato sexual não se destinava ao prazer, mas à procriação de filhos. Não que devesse ser evitado. Ao contrário, marido e mulher deviam empenhar-se no pagamento do "débito conjugal", mas também aqui sob certas regras; no caso da mulher, seu desejo devia ser apenas insinuado, e, segundo os manuais de confessores, o marido tinha de estar atento e apto a perceber e atender os sinais dissimulados emitidos pela esposa recatada e envergonhada. Afinal, recusar-se a pagar o débito era pecado, mas as regras não acabavam aqui: uma vez na cama, os teólogos e moralistas condenavam o coito com o homem em pé, sentado ou por baixo da mulher, casos em que o esperma procriador poderia desperdiçar-se ao não entrar no lugar certo. Daí a condenação da lascívia que despertava a louca paixão erótica e levava à cópula irresponsável, de puro prazer (ARAÚJO, 2004, p.4243).

Os mecanismos de controle que a Igreja utilizava para impor padrões de comportamento na vida dos colonos acabavam por criar espaços e necessidades que promoviam a violência contra as mulheres negras escravizadas e contra as mulheres negras libertas inferiorizadas e subalternizadas nesta sociedade. Se as mulheres brancas eram vistas como inferiores, no caso das mulheres negras esse processo chega a desqualificação da sua existência como seres humanos, portanto, objetos passíveis de usufruto. Daí o número elevado de abusos sexuais cometidos contra elas. O padrão rigoroso de comportamento preconizado pela instituição eclesiástica, que tanto vigiava a vida privada dos sujeitos, acabou por ser o alvitre que permitiu esse descompasso. 
Os ideais sociais do período colonial fizeram crescer os estereótipos de hipersexualização ${ }^{2}$ das mulheres negras. Desse modo, cria-se o antigo rótulo social por meio de que a mulher negra é identificada como possuidora de um apetite sexual aguçado. Esse pensamento é carregado por marcas do período colonial, as quais obliteram a crueldade que marcou os relacionamentos dos homens brancos com as mulheres negras, procurando evidenciar que elas buscavam essas relações para o prazer e que agiam de forma sedutora neste sentido. Assim, a vítima passa a condição de algoz:

Muitos são os estereótipos criados na sociedade. Eles ocorrem de
forma não consciente e regem o comportamento humano e o modo
como determinados públicos são vistos no meio social. Alguns
estereótipos existem de forma a prejudicar, principalmente, as
minorias sociais, em que as mulheres estão incluídas. No entanto,
alguns estereótipos são mais acentuados quando se refere às
mulheres negras, pois elas pertencem a duas classes de
desigualdade, a de gênero e a de raça/cor. Tal acentuação é
percebida através do estereótipo da mulher negra erótica e exótica,
uma construção histórico-cultural que se mantém socialmente,
através do fenômeno da hipersexualização (TELES; ADI, 2020, p.
01).

A citação acima nos direciona para uma reflexão sobre como o poder exerce função dominante na constituição identitária de grupos minoritários. Vejamos a questão da mulher negra como exemplo, pois uma vez marcada pela crueldade do período colonial, ela se molda, nas palavras de Teles, como erótica e exótica. No dicionário AURÉLIO, essas características apresentam o seguinte conceito:

\section{Erótico}

Adjetivo

1. Relativo ao amor.

2. Lúbrico, lascivo.

\section{Exótico}

Adjetivo

1. Que não é indígena; estrangeiro.

2. Excêntrico, extravagante.

(FERREIRA, 2010, p. 277 e 305)

Quando observamos o significado das duas palavras, vemos que ambas são adjetivos referentes a algo diferente do que é posto como "normal". A palavra erótico se relaciona ao amor, mas quando é definida pela palavra lascivo, aponta uma

\footnotetext{
${ }^{2}$ Segundo a Associação Americana de Psicologia, a hipersexualização acontece quando uma pessoa é vista como um objeto sexual e sua valorização se dá apenas por este apelo ou comportamento.
} 
inclinação para o amor carnal, com ênfase nos prazeres do sexo e do corpo. Já o adjetivo "exótico" refere-se ao que é alheio, estrangeiro, que não faz parte do habitual ou comum. Definido pela palavra excêntrico, o termo sugere, de acordo com o pensamento de Linda Hutcheon (1991, p.84) o sujeito que vive à margem da sociedade por não pertencer ao centro. Desse modo, os adjetivos usados para descrever a mulher negra possuem caráter pejorativo.

A mulher negra é caracterizada dessa maneira por uma construção históricocultural que teve como objetivo inferiorizá-la socialmente. Dessa forma, "quando se trata da mulher negra, ocorre um aumento dessa sexualização, o que auxilia no aumento do preconceito e da discriminação, interferindo na construção identitária desse público" (GOMES, apud TELES; ADI, 2020, p.01). O processo de constituição da imagem da mulher negra evidencia o poder exercido sobre ela e a objetificação que sofria, assim como Bueno reforça:

No Brasil, a objetificação das mulheres negras e de seus corpos teve início no sistema escravista do período colonial, em que as mulheres negras eram escravas sexuais de seus senhores. Algumas obras literárias confirmam essa prática, retratando a mulher negra com "cheiros e sabores" próprios, denotando sua noção de "utilidade" com um marcante destaque à sexualidade, como também uma submissão presente na época (BUENO, apud TELES; ADI, 2020, p.7).

Os estigmas referentes às mulheres negras, vinculados à raça/cor, disseminavam a ideia de que elas seriam mulheres fáceis, objetos sexuais, e que não se enquadrariam na condição de mulheres "para casar", pois possuíam um "apetite sexual inato" que as impossibilitava de alcançar esse feito. As mulheres negras eram assim "categorizadas como pecadoras, sendo distintas das mulheres eurodescendentes e vistas, principalmente, como pecadoras sexualmente disponíveis" (TELES; ADI, 2020, p.8).

Muitos viajantes vinham para o território brasileiro envolvidos por essas crenças disseminadas inclusive pelo discurso eclesiástico. Com os relacionamentos carnais inter-raciais, nascia o fruto dessa união. Filha de mãe negra e pai branco, essa mulher foi nomeada socialmente como "mulata", sendo fruto dessa violência, como a construção desse estereótipo sexualizado da mulher negra no Brasil, em que ela é vista como bonita, dengosa/fogosa, sensual, portanto, desejável (GOMES, apud TELES; ADI, 2020, p.8). 
Percebemos que a construção histórica e sociocultural da identidade feminina negra evidencia o preconceito, a discriminação e a violência de diferentes entidades de poder, o que ajudou na construção de um caráter de inferiorização de seus atributos em contraste com a mulher branca. Essa realidade se refletia nas relações de concubinato com homens brancos pois, quando ascendiam socialmente por meio dessa prática, não alcançavam seu espaço próprio, sendo obrigadas a viverem sob o espelho dos costumes e bons modos da mulher branca:

É verdade que as mulheres de cor, uma vez livres, adquiriam controle sobre seu destino, e o concubinato Ihes oferecia alternativas numa sociedade que, por princípio, Ihes negava qualquer forma de ascensão. Essas mulheres eram senhoras de seu viver e traçavam seu próprio destino. Entretanto, não podemos esquecer que, sob o manto dessa prática, não obstante as vantagens econômicas e sociais alcançadas, efetivava-se uma exploração dupla - de cunho sexual e racial -, pois a essas mulheres jamais foi propiciada a condição de esposas. Ainda, como veremos, por viverem no mundo dos livres, elas procuravam imitar seus hábitos, costumes, estilo de vida e indumentárias, de modo que reproduziam em escala menor o mundo daqueles que as haviam submetido à escravidão (FURTADO, 2003, p. 23).

É possível observar, então, que a mulher negra não se tornava livre das amarras sociais quando envolta no concubinato, pois se via diante de valores da elite, os quais a colocavam em condição de escravizada, não tendo seus próprios valores culturais aceitos, mas sim oprimidos, como vemos:

Portanto, em vez de ponto de partida para a constituição afirmativa de uma identidade negra, a alforria foi muitas vezes o início do processo de aceitação dos valores da elite branca, de forma a inserirse, assim como a seus descendentes, nessa sociedade. O processo de branqueamento étnico e cultural revela não as características democráticas entre as raças, mas as armadilhas sutis por meio das quais se esconde a opressão racial no Brasil (FURTADO, 2003, p. 23).

As mulheres negras foram vítimas de um sistema brutal, sofreram repressões e ataques sociais da elite, Estado e Igreja. As relações sociais dessas mulheres eram pautadas em violências físicas e emocionais que afligiam sua autoestima, pois o servilismo e a sexualização a definiram de tal forma que ela carrega alguns estigmas coloniais até os dias atuais. Mesmo quando buscavam uma liberdade, a qual nunca thes seria dada totalmente, ainda estavam cativas, pois pagariam o preço de aceitar se moldarem aos costumes e ideais de seus opressores: 
As mulheres negras não existem. Ou, falando de outra forma: as mulheres negras, como sujeitos identitários e políticos, são resultado de uma articulação de heterogeneidades, resultante de demandas históricas, políticas, culturais, de enfrentamento das condições adversas estabelecidas pela dominação ocidental eurocêntrica ao longo dos séculos de escravidão, expropriação colonial e da modernidade racializada e racista em que vivemos (WERNECK, apud, CUNHA; PAIVA, 2017, p. 3).

A citação reforça como as mulheres negras sofreram tentativas de apagamento na história brasileira, sendo descritas por meio de estereótipos que as inferiorizavam e a oprimiam no período colonial, e ainda hoje, "Criando-se assim, uma relação de coisificação, onde (sic) o ser humano não representa nenhum valor diante daquele que detém o poder e o status de superior" (CUNHA; PAIVA, 2017, p. 4). Portanto, sua construção identitária estereotipou-se ao longo do tempo evidenciando os pensamentos de servilismo e de subalternização ainda reinantes na contemporaneidade. Disseminada como "predadora sexual", "fácil", "fogosa" e "exótica", essas mulheres tornaram-se marco simbólico sexual brasileiro graças a construções socioculturais que atravessaram territórios e tempo, fortalecendo preconceitos e discriminações e relacionando sensualidade e erotismo à sua imagem de forma exorbitante.

\subsection{A FIGURA EMBLEMÁTICA DE CHICA DA SILVA}

A figura histórica Francisca da Silva Oliveira, conhecida popularmente como Chica da Silva, tem como cenário de sua existência o arraial do Tejuco, atual cidade mineira de Diamantina. Lá, Chica viveu a maior parte de sua vida, adquiriu um relacionamento estável com o contratador de diamantes João Fernandes Oliveira e ficou marcada para sempre na história mineira.

No século XVIII, as primeiras pessoas a se deslocarem para a região tiveram como motivo a busca do ouro, o qual trouxe muita riqueza para Portugal. Porém, na década de 1720 , com o descobrimento dos diamantes nos ribeirões mais próximos da região Diamantina, a diminuta população que havia nos arraiais mais próximos se deslocou toda para o Tejuco. "A febre dos diamantes era tal, que naquela vila, trocava-se uma casa por um freio de cavalo, ou vendiam-se todas as posses para comprar escravos, com os quais se exploravam as lavras das preciosas pedras" 
(FURTADO, 2003, p. 29). Além disso, outro aspecto diamantino chamava a atenção de quem conhecia o pequeno arraial, sua exuberante beleza natural:

A região Diamantina impressionava os viajantes pela força da natureza. O frânces Alcide D' Orbigny afirmou que seu solo era quase sagrado pelas riquezas que ocultava, e cada pedra, privilegiada. O naturalista José Vieira Couto a descreveu como uma visão "negra, arrepiada e crespa", composta por "mil picos de serra desiguais, [...] montes elevadíssimos de uma só pedra e perpendicularmente talhados [que] se elevam às nuvens". Mato rasteiro ou musgo pardo cobriam partes da terra, quase estéril. Mas para o descanso dos viajantes, por ali corriam, atravessando os caminhos, "mil regatos de puras e cristalinas águas". Alguns caíam "a pique e em fio de altíssimas montanhas"; outros se quebravam e dividiam "sobre rochas até o sopé das serras", e após voltas e reviravoltas desaguavam em rios maiores. Às vezes mansos, os regatos se abriam em espaçosas praias de areias brancas ou, serpenteando entre as serras apertadas, sumiam de vista para reaparecer ao longe, com fúria. Por toda parte a natureza compunha um espetáculo inesquecível (FURTADO, 2003, p. 31-32).

Minas Gerais era, no século XVIII, centro de grande urbanização e de instalações importantes da Coroa, pois foi palco de exploração primeiramente de ouro e depois de diamantes, que gerou muitos lucros a Portugal e aos envolvidos no processo exploratório. Notamos que as descrições mostram um território natural, que impactava por seus picos altíssimos e seu solo intocado. Sua aparência não foi apenas o que causou espanto em seus novos habitantes e visitantes, o clima tropical oscilava entre os 14 e 27 graus, havendo uma leve queda apenas nos meses de junho e julho. As estações eram marcadas por seca e chuvas. A primeira ocorria de abril a setembro. Quando chegavam, as chuvas "não eram mansas e miúdas, mas grossas e ruidosas, e se arrastavam por dias e semanas. $O$ alarido dos trovões retumbava na serra e fazia tremer a terra, assustando os moradores" (FURTADO, 2003, p. 32). Por esse motivo, a mineração ocorria por volta de abril, quando a chuva cessava e a seca começava.

Com a riqueza de pedras na região, fez-se necessária a implantação de uma administração específica nomeada de Intendência dos Diamantes, cuja sede era no Tejuco.

A constituição da cidade de Diamantina ocorria por uma expressiva quantidade de negros escravizados, uma menor proporção de homens e mulheres negros libertos, e a pequena classe da elite branca, a qual ocupava os principais cargos administrativos. Seus principais valores baseavam-se em critérios de 
nascimento e honra. Dessa forma, as pessoas de tonalidade parda e livres buscavam alguma forma de ascensão social, principalmente as mulheres, "muitas vezes por meio do concubinato com um homem branco, ou pelas vendas de tabuleiro e a prestação de pequenos serviços de entrega e até prostituição" (FURTADO, 2003, p. 43).

A figura emblemática de Chica da Silva, que marcou a sociedade diamantina durante o século XVIII, nasceu por volta de 1731 a 1735, não havendo uma data exata, no arraial do Milho Verde. Nasceu na condição de escrava, e "era filha de Maria da Costa, escrava negra, e de Antônio Caetano de Sá, homem branco" (FURTADO, 2003, p.47). Junia Furtado (2003, p.49) afirma que vários documentos comprovam que "Chica da Silva era mestiça, ora descrita como parda, ora como mulata, filha de uma negra com um branco".

O primeiro documento sobre Chica no Arraial do Tejuco é do ano de 1749, referente ao batizado de uma criança negra, da qual ela foi madrinha. Sabe-se que Chica da Silva foi vendida como escrava ao médico Manuel Pires Sardinha e passou o início de sua adolescência como escrava dos afazeres domésticos na casa do médico. Como era comum na época, as escravas eram forçadas a manter relações com seus proprietários e, assim, Chica engravidou em 1751 desse médico, tornando-se mãe, pela primeira vez, de um menino, nomeado Simão, que nunca teve sua paternidade assumida.

João Fernandes de Oliveira nasceu no Brasil em meados de 1727, primogênito do sargento-mor João Fernandes de Oliveira e de Maria de São José, filha de comerciantes do Rio de Janeiro. Seu nome pertencia a uma tradição familiar, sendo passado de geração em geração. Quando jovem, seu pai o mandou para Portugal, para estudar, chegando a frequentar mais tarde a Universidade de Coimbra. Retornado ao Brasil em 1753, com o título de desembargador e com a tarefa de representar seu pai no quarto contrato dos diamantes ${ }^{3}$. "Era um rapaz coberto de glória, cuja trajetória, cuidadosamente planejada pelo sargento-mor João Fernandes de Oliveira, refletia o processo de notabilização e ascensão social" (FURTADO, 2003, p. 73). Seu futuro foi planejado de forma meticulosa pelo seu pai,

\footnotetext{
3 O sistema de contratos era uma prática comum na administração portuguesa, os quais eram arrematados a cada quatro anos por mãos particulares e concediam a exploração dos diamantes. Dessa maneira, a Coroa tinha seus rendimentos garantidos, sem a necessidade de prover a organização do trabalho efetivo.
} 
que esperava que ele alcançasse uma ótima colocação social, evidenciando a família Oliveira na sociedade portuguesa:

No segundo semestre de 1753, pouco depois de chegar ao Tejuco e assumir suas funções, João Fernandes de Oliveira comprou de Manuel Pires Sardinha, por 800 mil réis, a escrava parda Chica. Não se conhecem ao certo os motivos que levaram Pires Sardinha a vendê-la, porém vale lembrar que em agosto daquele mesmo ano, durante a devassa episcopal, o médico assinara o compromisso de se "apartar [sic] da ilícita comunicação" que mantinha com duas escravas de sua propriedade. Vender essas mulheres, de maneira que vivesse em casas separadas, era condição essencial para o cumprimento dos termos do compromisso (FURTADO, 2003, p.103).

Os motivos que levaram o desembargador e contratador dos diamantes João Fernandes de Oliveira a comprar a escrava Chica da Silva não são conhecidos, porém, como Furtado explica, o médico Manuel Pires Sardinha, que era o dono da escrava, precisava vendê-la. Ocorre que com a devassa episcopal, ele era julgado pelo crime de concubinato e bigamia, já que mantinha relações com as escravas Francisca parda (Chica da Silva) e com Francisca crioula, resultando em um filho com cada uma delas, fato que acarretou na sentença de culpado no processo, sendo, portanto, obrigado a vendê-las para donos diferentes.

É provável que João Fernandes de Oliveira a tenha comprado com a intenção de torná-la sua companheira, apesar de não haver documentos que comprovem suas intenções. Porém, é possível que em alguns meses posteriores à sua compra, já existisse uma relação amorosa entre os dois, pois em dezembro do mesmo ano, o contratador assinou a carta de alforria de Chica, o que não configurava uma prática comum na época para escravos recém-comprados:

[...] Chica da Silva teria entre dezoito e 22 anos quando João Fernandes, então com 26 anos, a conheceu. A jovem, mãe de uma criança de dois anos - a vida sexual das escravas se iniciava precocemente, entre os doze e os catorze anos -, possuía a beleza das mulheres oriundas da Costa Mina, com frequência elogiadas pelos europeus. Os documentos da época a designam como parda, termo que se descrevia a tonalidade de pele mais clara entre os mestiços. Embora não conhecemos os efeitos que Chica da Silva provocou em João Fernandes, a atração que mulheres como ela exerciam pode ser compreendida por meio de um cronista estrangeiro (FURTADO, 2003, p. 113).

Quando Chica da Silva e João Fernandes de Oliveira se conheceram, eles eram jovens. Chica já era mãe, mas acredita-se que fosse uma mulher bonita e 
atraente para os padrões da época. Apesar de não existirem documentos oficiais ou imagens que revelem os aspectos físicos de Chica, muitos estrangeiros que visitavam o território brasileiro no período retratam em versos, contos e crônicas, a exuberante beleza das mulheres africanas, reforçando os estereótipos criados em torno delas. $O$ cronista que Furtado cita é Carl Schlichthorst que, em sua crônica $O$ Rio de Janeiro como é (1824-1826): uma vez e nunca mais, contextualiza:

(...) doze anos é a idade em flor das africanas. Nelas há de quando em quando um encanto tão grande, que a gente esquece a cor... As negrinhas são geralmente fornidas e sólidas, com feições denotando agradável amabilidade e todos os movimentos cheios de uma graça natural, pés e mãos plasticamente belos. Dos olhos irradia um fogo tão peculiar e o seio arfa em tão ansioso desejo, que é difícil resistir a tais seduções (SCHLICHTHORST, apud FURTADO, 2003, p.113).

No trecho acima, notamos que as descrições são feitas com entonação de atração pelo padrão físico descrito. A mulher negra seria símbolo de beleza exótica durante o século XVIII, o que aumentava a libido masculina, adensando a procura por relacionamentos carnais com essas mulheres. O que ocorria com a "mulata" que apresenta o estereótipo sexual mais marcado é a mistura das raças, sendo possuidora de aspectos físicos herdados da mãe e tonalidade de pele mais clara, herdada do pai, o que resultava para os padrões do período em uma composição dos melhores traços sanguíneos de ambos os envolvidos. A beleza desta mulher é perceptível por um relato do inglês John Gabriel Stedman:

[...] de estatura mediana, ela era perfeita, com as mais elegantes formas que podem ser vistas na natureza, movendo suas bem formadas pernas como uma deusa quando caminha. Sua face era cheia da modéstia nativa e da mais distinta doçura. Seus olhos, negros como ébano, eram largos e cheios de expressão, demonstrando a bondade do seu coração. [...] Seu nariz era perfeito, bem formado e quase pequeno; seus lábios eram um pouco proeminentes e, quando ela falava, mostravam duas perolas tão branca quanto as montanhas de neve. Seu cabelo era escuro, quase preto, formando um lindo globo de pequenos anéis (STEDMAN, apud FURTADO, 2003, p.114).

O trecho acima reforça que as características físicas consideradas fatores de atração ao desejo masculino e que se ajustavam aos padrões estéticos europeus da época. Essas mulheres eram consideradas belas por terem proporções adequadas das partes de seu corpo, cor agradável e um ar de graça. Retratada historicamente em primeiro lugar pelo texto de Joaquim Felício dos Santos (1822-1895) publicado 
em 1868 e intitulado Memórias do Distrito Diamantino da Comarca do Serro Frio (Província de Minas Gerais), Chica da Silva foge dos padrões de beleza anteriormente mencionados. O autor a descreve como sendo careca e detentora de traços grotescos. Tais descrições foram contestadas por escritos posteriores (como Júnia Furtado e Conceição Evaristo) os quais entendem que, como João Felício escrevia seu texto sob a égide dos olhares dos homens do século XIX, portanto marcado por outras concepções, não sendo capaz de entender a atração do homem do século anterior ao seu.

O relacionamento entre Chica da Silva e o contratador João Fernandes de Oliveira durou dezessete anos, período em que ele viveu em Minas, antes de voltar para Portugal. Durante esse tempo, tiveram treze filhos, quatro homens e nove mulheres. João Fernandes fez com que ela acumulasse alguns bens em seu nome e que usasse seu sobrenome, como uma forma de ascensão social, apesar de o relacionamento ser considerado ilegítimo para as leis da época:

As atitudes de João Fernandes demonstram sua intenção de conferir à relação com Chica da Silva os ares de um matrimônio estável, mas não legal - o qual deveria somente ser constituído entre indivíduos de mesmo status -, como a alforria precoce, a promoção para que ela acumulasse patrimônio, o uso que Chica fez do sobrenome Oliveira, o número elevado de filhos, cujos nomes se ancoram nas tradições familiares dos pais, e a longevidade do relacionamento (FURTADO, 2003, p.119).

A escritora aponta fatos que comprovam que, apesar de não poderem legitimar sua união, o contratador João Fernandes de Oliveira e a ex-escrava Chica da Silva mantiveram uma relação estável e assumida. O nome dos filhos, como o do primogênito, João Fernandes de Oliveira Grijó ${ }^{4}$, releva os traços da afetividade do contratador com a mulher e filhos, pois o nome compõe a tradição familiar passada de geração para geração na família Oliveira. Ademais, ele legitimou e deixou seu patrimônio para todos os treze filhos que teve com Chica, reafirmando que não haveria dúvidas em relação à paternidade da prole.

Algumas atitudes de Chica da Silva apontam a ascensão social que experimentou ao unir-se com o contratador João Fernandes de Oliveira. Diferente da primeira gestação que teve, os outros trezes filhos, frutos de seu relacionamento,

\footnotetext{
${ }^{4}$ Recebeu o sobrenome Grijó devido a ser titulado como herdeiro do morgado de seu pai, que se intitulava morgado de Grijó.
} 
foram amamentados por amas de leite, escravas que eram compradas ou usadas diretamente para esse fim. Tal costume era praticado por senhoras brancas de seu tempo, comprovando que Chica soube se adaptar à nova vida e portou-se conforme se impunham os padrões sociais da época:

Explica-se a amamentação dos recém-nascidos pelas amas de leite não como descuido das mães, mas sim como cumprimento de um papel que a sociedade destinara às damas pertencentes às classes mais altas - o de gerar numerosa prole, a fim de garantir a perpetuação da família (FURTADO, 2003, p.123).

Desse modo, notamos o embranquecimento social de Chica por meio do ato de não amamentar seus filhos, cumprindo os padrões da época como mulher pertencente a elite social. Ela também possuía uma numerosa prole com o contratador, composta por treze filhos.

Os textos apontam que Chica da Silva apropriou-se de normas e padrões de comportamento que eram esperados das mulheres brancas que compunham a elite social da colônia, entre eles a adoção de amas de leite para alimentar os filhos; grande quantidade de vestidos, anáguas, capas, sapatos, fivelas, joias e pedras preciosas, pois as posses eram um indicativo de riqueza e ascensão social.

Para além dos costumes em relação ao modo de vestir, o processo de embranquecimento social de Chica também se deu pela posse de escravos. Mesmo sendo ela uma ex-escrava, era prática comum no tempo que aqueles e aquelas que haviam conseguido atingir alguma forma de ascensão social e se tornassem libertos e libertas o fizessem.

Ainda em relação à imersão nos costumes de uma mulher branca da época, ser aceita pela Igreja era um grande passo para a ascensão social de Chica da Silva, já que a entidade religiosa detinha em suas mãos um grande poder social. Dessa maneira, Chica, juntamente com outras mulheres, patrocinou a Irmandade do Rosário, instituição em que mais tarde ela participou nas mesas diretoras, sendo juíza em duas delas. Esses fatos comprovam sua aceitação pela Igreja de forma pública. Chica buscava apagar seu passado como escrava, aproximando-se da elite e tendo acesso a uma cultura refinada, a qual o contratador fez questão de oferecer.

Chica seguiu à risca os modelos cristãos de devoção e transmitiu aos filhos ensinamentos sobre os atos essenciais dessa fé, indispensáveis para a elevação da alma ao paraíso após a morte. Mas seus motivos não eram estritamente religiosos: tornar pública 
sua aceitação sem restrições do catolicismo foi o modo pelo qual ela e seus descendentes alcançaram bom trânsito social no seio da elite branca e católica do arraial (FURTADO, 2003, p. 182).

O fato de ter vivido em Portugal propiciou a João Fernandes um gosto refinado em termos musicais e também o fez apreciar o teatro. $O$ casal frequentava saraus, peças de teatro e apresentações musicais, na maioria das vezes promovidas pelo próprio João Fernandes. Chica demonstrava preocupação com a instrução, o que a levou a aprender a fazer sua assinatura, um ato que a dignificava como senhora pertencente à elite. Nesse sentido, verifica-se que ela também tinha grande preocupação com os estudos de seus filhos, fato constatado por meio de documentos que atestam que suas nove filhas foram "internadas no Recolhimento de Nossa Senhora da Conceição de Monte Alegre de Macaúbas, o melhor educandário da capitania, onde teriam a garantia de uma vida devota e honrada" (FURTADO, 2003, p.189).

A intenção de Chica era que suas filhas tivessem uma educação formal, digna e de qualidade, pois, por esses meios, elas teriam mais chances de ascender socialmente, seguindo carreira religiosa ou realizando um bom casamento. Dessa forma, Francisca de Paula, Helena, Rita Quitéria, Ana Quitéria e Antonia professaram seus votos e tornaram-se freiras, porém apenas Antonia seguiu a carreira religiosa, enquanto as demais se juntaram às irmãs Luisa Maria, Maria, Quitéria Rita e Mariana de Jesus, conseguindo casamentos bem-sucedidos. Já os meninos João Fernandes, Joaquim, Antônio Caetano e José Agostinho estudaram primeiramente com curas e professores no Tejuco e, após esse período preliminar, seguiram para Portugal, onde reencontraram o pai e cursaram faculdade, apesar de não haver registros exatos que definam qual universidade frequentaram.

Apesar de o historiador Joaquim Felício dos Santos defender que o motivo do retorno do contratador de diamante João Fernandes de Oliveira para Portugal ocorreu por um mandado de prisão devido a supostos contrabandos e irregularidades, Junia Furtado afirma que não há nenhum registro que comprove essa informação. Ela ainda ressalta que seu retorno se dera em razão da morte do pai de João Fernandes, resultando em uma briga judicial com a viúva Isabel, mulher com a qual seu pai casara após a morte de sua mãe, e que fizera passar para si uma quantia maior do que usualmente se deixava para as esposas em caso de morte. Tal conflito teria se estendido por muitos anos, ocasionando a quebra do seu 
contrato de diamantes e o impossibilitando de voltar para o Brasil e para Chica da Silva. Alguns anos mais tarde, acometido por uma doença, João Fernandes veio a óbito, em 1779.

Com a partida de João Fernandes de Oliveira do Tejuco, Chica passou a conviver em sua casa com suas filhas, falecendo naquele pequeno arraial no dia 16 de fevereiro de 1796. O modo como experienciou suas últimas horas de vida e como se apresentou seu enterro comprovam que ela conseguiu ascensão social:

Estava acompanhada do pároco, que Ihe ministrou a extrema-unção,
perdoando seus pecados e consolando-a na agonia. Não era mais
uma escrava parda sem nada de seu; era senhora de "grossa casa",
possuidora de bens imóveis e de numerosos escravos. O
reconhecimento social que alcançara foi demonstrado em seu
sepultamento: Chica foi sepultada na tumba número 16, no corpo da
igreja da Irmandade de São Francisco de Assis, que teoricamente
congregava apenas a elite branca local, merecedora do privilégio de
dispor de todos os ritos e sacramentos funerários que distinguiam os
irmãos (FURTADO, 2003, p. 245).

O enterro na igreja da Irmandade de São Francisco de Assis confirma a tese de que Chica alcançou ascensão social. Sua trajetória foi marcada pela tentativa de embranquecimento, apagando seu passado na condição de escrava, glorificando-se como senhora do Tejuco no século XVIII e garantindo espaços de respeito para todos os seus filhos na sociedade diamantina. As imagens disseminadas por alguns historiadores e escritores ficcionais retratam-na como megera, bruxa, caprichosa, feia, sádica, sensual, "devoradora de homens", entre outros estereótipos pejorativos. Fontes históricas, entretanto, comprovam que sua trajetória esteve diretamente ligada ao desejo de ser aceita pela sociedade da qual passou a fazer parte devido a sua relação com o contratador João Fernandes. Desse modo, comportou-se dentro da moral religiosa e social da elite branca, figurando como senhora na sociedade tejucana. 


\section{O SURGIMENTO DO ROMANCE HISTÓRICO TRADICIONAL}

Embora o conceito de romance histórico tenha surgido a partir da obra de Walter Scott, no século XIX, já nos séculos XVII e XVIII é possível encontrar romances com temática histórica, os quais são nomeados como romance social. Estes escritos abordavam as questões históricas contemplando, por exemplo, a descrição da vestimenta das personagens, sem se preocupar com sua construção psicológica ou mesmo em retratar os hábitos e costumes da época em que se ambientavam.

O romance social realista do século XVIII apresentava divergências com os ideais do romance histórico, pois a sua representação dos costumes e psicologia do seu tempo origina uma abertura para a realidade, mas não apresenta a problemática da determinidade temporal completa dos homens retratados. "O presente histórico é figurado com extraordinária plasticidade e verossimilhança, mas é ingenuamente aceito como um ente" (LUKÁCS, 2011, p. 34). Desse modo, a representação abstrata do tempo histórico ocasiona consequências na figuração do espaço histórico.

O gênero que mais se aproximou da problemática do romance histórico foi o romance social inglês. Ele direcionou a visão do escritor a uma espécie de "significado concreto (isto, é histórico) do espaço e do tempo, das condições sociais etc.; foi ele que criou o meio de expressão literário, realista, para a figuração dessa especificidade espaço-temporal, isto é, histórica dos homens e das relações" (LUKÁCS, 2011, p. 36). Porém, os pressupostos do romance social inglês, mesmo possuindo um instinto realista, não evidenciavam alguma tentativa de trabalhar com a história como um processo, ou seja, "sobre a história como precondição concreta do presente" (Idem, p. 36).

Alguns acontecimentos históricos marcaram o surgimento do romance histórico, como a Revolução Francesa, as guerras revolucionárias, a ascensão e a queda de Napoleão, pois por meio deles as pessoas começaram a sentir-se parte da história. Dessa maneira, o pensamento social existente da época, que via as revoluções como um acontecimento natural, passa a vê-lo como histórico. O que resulta na percepção da história como um processo contínuo de mudanças, impactando de forma direta na vida dos sujeitos. 
Nesse contexto em que se encontrava a sociedade, a literatura foi o meio de maior procura como forma de expressar os sentimentos e pensamentos vigentes. Assim, como Vera Follain de Figueiredo afirma: "o romance histórico integra o elenco das grandes narrativas de consolidação do sentimento nacional e, ao mesmo tempo, de legitimação do impulso universalizante do Ocidente" (FIGUEIREDO, 1997, p. 480). Desse modo, os homens começam a compreender e refletir sobre a condição de sua existência cotidiana interligada aos acontecimentos sociais. Sobre isso informam Lavorati e Teixeira que:

Desse modo, podemos concluir que o romance histórico clássico
surgiu em meio a transformações sociais, políticas e econômicas que
trazem à tona, nos indivíduos, a consciência da importância da
história e do peso dos seus reflexos na vida dos homens. Idéias,
essas, que entram em consonância com a aceitação do caráter
científico que será proposto pela história (LAVORATI; TEIXEIRA,
2010, p. 02).

Isso faz com que uma "consciência progressiva do caráter histórico do desenvolvimento também começasse a se evidenciar no juízo crítico sobre as condições econômicas e as lutas de classe" (LUKÁCS, 2011, p.41), o que aproxima os indivíduos da tendência do historicismo e, ao mesmo tempo, os afasta dos ideais iluministas:

\begin{abstract}
A partir dessas considerações, fica claro que a tendência do historicismo a tornar-se consciente atinge seu ápice no período após a queda de Napoleão, na época da Restauração, da Santa Aliança. É evidente que o espírito desse historicismo, que pela primeira vez domina e torna-se oficial, é reacionário e, em sua essência, pseudohistórico. A concepção da história, o periodismo e a beletrística do legitimismo desenvolvem o espírito histórico em áspera oposição ao iluminismo, às ideias da Revolução Francesa. O ideal do legitimismo é o retorno às condições anteriores à Revolução Francesa, expurgando da história as maiores realizações da época (LUKÁCS, 2011, p. 42).
\end{abstract}

Com isso, os indivíduos, por meio de um novo espírito histórico, começam a questionar os ideais sobre o progresso humano do lluminismo. Assim, o progresso deixa de ser visto como processo anistórico da razão humanista, ou seja, que a evolução humana não possuiria ligação alguma com a história. Dessa maneira, a nova concepção de racionalidade do "progresso humano é desenvolvida de modo cada vez mais acentuado a partir do conflito interno das forças sociais na própria 
história" (LUKÁCS, 2011, p. 43), ou seja, "de acordo com essa concepção, a própria história deve ser a portadora e a realizadora do progresso humano" (Idem, p. 43).

Com a constituição de uma consciência histórica nos indivíduos, as lutas de classes passam a exercer um papel fundamental no progresso da humanidade. Desse modo, segundo Gyorgy Lukács, é por meio de importantes historiadores franceses do período da Restauração, que se dedicavam à ideia de que a sociedade moderna seria resultado de lutas de classes entre a nobreza e a burguesia, que "surge pela primeira vez uma tentativa de periodização racional da história, uma tentativa de apreender de modo racional e científico a especificidade histórica e a gênese do presente" (LUKÁCS, 2011, p. 43).

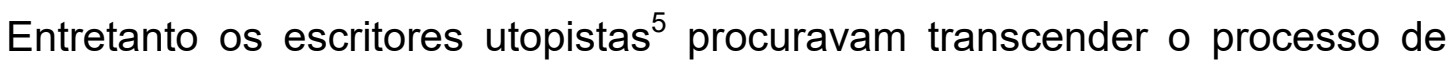
periodização da história, utilizando-se de caminhos fantasiosos para suas descrições e, ao mesmo tempo, apresentando fundamentação critica em seu trabalho, ou seja, aproveitando o espaço para realizar críticas a respeito das contradições da sociedade burguesa.

As novas problemáticas a respeito da relação do indivíduo e a história impulsionaram um novo pensamento ideológico, a filosofia hegeliana, fundada por Georg Wilhelm Friedrich Hegel. Essa teoria contestava a ideia iluminista de que o sujeito seria imutável e que, em casos extremos, a história poderia resultar apenas em alterações de costumes. Assim, "ela vê o homem como produto de si mesmo, de sua própria atividade na história" (LUKÁCS, 2011, p. 44). Ou seja, o progresso do sujeito ocorreria por si mesmo e pelo impacto que as revoluções e incontáveis mudanças da História causariam nele. Isso refletiria drasticamente no rumo da literatura do período, como vemos:

No século XIX, época de ímpeto iluminista e crença num progresso que seria alcançado por meio da construção das nações, o diálogo ficção/História ganha terreno propício para se desenvolver devido à necessidade, que se fez presente, da construção de uma história nacional. Surgem, então, narrativas com a pretensão de reconstituir um determinado tempo, acontecimento, fato do passado (LAVORATI; TEIXEIRA, 2010, p. 02).

Com as bruscas mudanças sociais e a transformação dos sujeitos surge o romance histórico, havendo como pioneiro do gênero o escritor inglês Walter Scott. Gyorgy Lukács (2011) afirma que Scott não conheceu a filosofia hegeliana, e que se

\footnotetext{
${ }^{5}$ Escritores que possuíam projetos idealistas, grandiosos e fantasiosos sobre o mundo.
} 
tivesse algum tipo de contato com ela não entenderia uma palavra sequer, pois a nova concepção de história é posterior à suas obras e algumas problemáticas são influenciadas por elas. "O romance histórico scottiano é continuação direta do grande romance social realista do século XVIII" (LUKÁCS, 2011, p. 47). Scott realizava estudos de obras de precursores do romance social, porém Lukács (2011) afirmar que as obras de Scott eram completamente diferenciadas e únicas em contraste com as obras dos escritores que ele estudava. Lukács utiliza-se de Balzac para reafirmar sua colocação, como podemos ver:

E Balzac ressalta, em sua crítica a $A$ cartuxa de Parma, de Stendhal, os novos traços estéticos que o romance de Walter Scott introduziu na literatura épica: o amplo retrato dos costumes e das circunstâncias dos acontecimentos, o caráter dramático da ação e, em estreita relação com isso, o novo e importante papel do diálogo no romance (LUKÁCS, 2011, p. 47).

Com a citação acima, notamos que Walter Scott apresenta peculiaridades em sua obra que o diferenciam de escritores de sua época, sendo seu trabalho considerado revolucionário. Dessa maneira, Lukács (2011) realça o fato de ele residir na Inglaterra, pois durante o romance social inglês os escritores desse país apresentavam os melhores traços realistas. Portanto, seu destaque seria algo provável pela consagração da literatura local á qual pertencia.

A relativa estabilidade do desenvolvimento inglês nessa época conturbada, em comparação com continente, possibilitou que o sentimento histórico recém-despertado pudesse se condensar em uma forma grandiosa, objetiva e épica. Essa objetividade é intensificada ainda pelo conservadorismo de Water Scott. Com sua nova visão de mundo, ele permanece fortemente ligado às camadas da sociedade arruinadas pela Revolução Industrial, pelo rápido desenvolvimento do capitalismo. Scott não faz parte nem dos entusiastas do desenvolvimento nem de seus apaixonados e patéticos contestadores. Por meio da investigação de todo desenvolvimento inglês, procura encontrar um caminho "mediano" entre os extremos em lutas. Na história inglesa na história inglesa, encontra consolo de a violenta oscilação das lutas de classes ter sempre acabado por apaziguar-se em um glorioso "meio" (LUKÁCS, 2011, p. 48).

Dessa maneira, Walter Scott procurava encontrar o "caminho do meio" entre os extremos, dedicando-se em "demonstrar sua realidade histórica pela figuração ficcional das grandes crises da história inglesa" (LUKÁCS, 2011, p. 49). Essa 
particularidade de Scott estava evidente na maneira como desenvolvia sua trama, escolhendo sua personagem principal e caracterizando o "herói":

O "herói" do romance scottiano é sempre um gentleman inglês mediano, mais ou menos medíocre. Em geral, este possui certa inteligência prática, porém não excepcional, certa firmeza moral e honestidade que beiram o sacrifício, mas jamais alcançam o nível de uma paixão humana arrebatadora, de uma devoção entusiasmada a uma causa grandiosa. Não são só os Waverley, Morton, Osbaldiston etc. que encaram esses representantes medianos, corretos e honestos da pequena nobreza inglesa, mas também Ivanhoé, o Cavaleiro "romântico" da idade média (LUKÁCS, 2011, p. 49).

O herói das obras de Scott diferenciava-se do típico herói do romantismo romântico, pois representava uma nova concepção dentro da narrativa. O que ocasionou inúmeros ataques de críticos literários em relação a isso, como por exemplo, por Taine que considerava essa sua escolha um instrumento de mediocridade ficcional, porém, para Lucáks (2011), o talento de Scott marcou toda sua época, e do ponto de vista psicológico e biográfico; é provável que esse estilo escolhido expressasse sua opinião pessoal com respeito à nobreza, como enfatizado:

Ele se esforça para figurar as lutas e as oposições da história por meio de homens que, em sua psicologia em seu destino, permanecem sempre como representantes de correntes sociais e potências históricas. Scott entende esse modo de conceber aos processos de marginalização; considera-a sempre em sentido social, e não individual. Seu entendimento do problema do presente não é profundo suficiente para resolver essa questão dos processos de marginalização. Por isso, ele se desvia da temática e conserva, em sua figuração, a grande objetividade histórica do épico legítimo (LUCÁKS, 2011, p. 50).

As peculiaridades citadas acima a respeito das obras de Scott evidenciam como sua busca se aproximava das camadas marginalizadas da sociedade, ou seja, o enfoque da narrativa estava em apresentar os dois lados da história, o da elite e o do povo. Dessa maneira, o escritor fazia uso de dados historiográficos e de pessoas históricas conhecidas, porém, em algumas obras, a figura central de suas narrativas o "herói mediano", era representado por uma pessoa histórica desconhecida socialmente.

Scott não possuiu a grandiosa e profunda dialética psicológica das personagens que caracterizam o romance do último grande período 
do desenvolvimento burguês. Também não alcança a altura que chegou o romance burguês na segunda metade do século XVIII com Rousseau, Choderlos de Laclos e Goethe, com seu Werther. Púchkin e Manzoni, seus maiores sucessores no romance histórico, também o superaram largamente em profundidade e poesia das figuras humanas individuais. Mas a reviravolta que Walter Scott realiza na história da literatura universal é independente dessa estreiteza de horizonte humano-ficcional. A grandeza de Scott está em dar vida humana a tipos sociais históricos. Antes de Scott, os traços humanos típicos, em que se evidenciam as grandes correntes históricas, jamais haviam sido figurados com tal grandiosidade, univocidade e concisão. E, acima de tudo, jamais essa tendência da figuração havia sido trazida conscientemente para o centro da representação da realidade. (LUKÁCS, 2011, p. 51).

Como Lukács afirma, Scott foi fundamental para o início do romance histórico, pois seu trabalho abordava uma nova leitura sobre a história e a representação humana. Ademais, sua narrativa trabalhava tanto com figuras históricas conhecidas, como desconhecidas, o que não era comum na época. Porém, o aprofundamento psicológico das personagens não foi enfoque dos trabalhos do escritor, o que foi feito apenas pelos seus sucessores, como apresentado na citação anterior, pois o escritor se preocupava em apresentar os acontecimentos históricos.

Nesse sentido, o romance histórico clássico, conforme o modelo
scottiano, é uma narrativa que tem o passado anterior à época do
escritor como pano de fundo, entrelaçando-se história e ficção, e
descrevendo a transformação da vida de uma determinada
sociedade, cujas personagens principais são fictícias e não históricas
(SANTOS, 2009, p.124).

Como a citação acima evidencia, as obras de Scott possuíam como inspiração algo histórico, como fatos ou pessoas, porém, eram narrativas puramente ficcionais. Ademais, uma das preocupações de Scott era apresentar o acontecimento histórico, de modo que os leitores compreendessem o que sem sua obra é narrado como processo histórico, ou seja, como algo que nasce de certos fundamentos, que possui perspectivas opostas e que as camadas sociais são todas afetadas pelos acontecimentos, porém de maneiras e intensidades diferentes. Assim, ele usa o evento histórico como a problemática da narrativa, ao mesmo tempo em que faz uso de elementos ficcionais para estruturar sua narrativa de modo a construir a credibilidade de sua obra.

\subsection{O ROMANCE HISTÓRICO NO BRASIL}


No Brasil, o romance histórico surgiu alguns anos após a sua consolidação na Europa. Segundo Antônio R. Esteves, as "primeiras manifestações literárias coincidem com o período ligeiramente posterior à Proclamação da Independência" (ESTEVES, 2010, p. 25). Dessa maneira, o seu surgimento estava ligado ao "conceito de nação brasileira e também da construção de um cânone cultural e literário que reafirmasse as diferenças do novo país ante a antiga metrópole lusitana" (ESTEVES, 2010, p. 25). Isso resultou no surgimento das primeiras obras híbridas, baseadas em acontecimentos e/ou pessoas históricas, como podemos ver:

Nesse contexto, as primeiras décadas do Brasil independente veem surgir uma série e narrativas híbridas, divulgadas em forma de folhetins pelos nascentes periódicos, que podem ser consideradas como uma espécie de proto-história tanto do romance como gênero quanto do romance histórico no Brasil, antes de sua consolidação pela pena do cearense José de Alencar (1829-1877) (ESTEVES, 2010, p. 25).

As primeiras narrativas brasileiras que trabalhavam com a relação história e ficção não eram consideradas romance histórico, pois suas estruturas pertenciam ao gênero crônica e, eram publicadas em folhetins. O primeiro escritor brasileiro a apresentar em sua narrativa essa problemática foi Francisco Adolfo de Varnhagen em 1840, publicando uma crônica do descobrimento do Brasil em formato de folhetim, nas páginas do periódico lusitano O Panorama. O seu trabalho abordava a temática histórica de cunho ficcional, como enfatizado:

Trata-se, segundo Massaud Moisés (1984, p. 62), de "um voluminho de escassas 60 páginas" que "respira o clima medievalizante" do periódico lusitano. "Misto de ficção e história, mais esta que aquela, o texto relata, à luz da carta de Pero Vaz de Caminha, os dias de Cabral e seus companheiros" (ibidem). Não falta sequer o idílio fictício entre a índia Ypepa e o navegante Braz Ribeiro, sob influência evidente de Scott, via Herculano. O próprio Varnhagen publicaria mais tarde (1852) um "romance histórico", na linha da tradição ibérica, com o título de Caramuru, que revive "à custa dos hábitos nativos, as intenções apologéticas de Santa Rita Durão" (Bosi, 1979, p.109). Trata-se, entretanto, nesse caso, de uma composição em versos, que segue a tradicional forma do "romance", que desde a Idade Média relatava feitos heróicos na Península Ibérica (ESTEVES, 2010, p. 25).

A temática do trabalho de Francisco Adolfo de Varnhagen coincide com a esfera do romance histórico, porém as características de sua obra não a enquadravam como pertencente ao gênero romance histórico. Ademais, quando o 
gênero chegou ao Brasil, Varnhagen foi um adepto dele, publicando o romance histórico Caramuru, porém não foi o primeiro escritor brasileiro a aderir ao gênero. $\mathrm{O}$ primeiro escritor brasileiro a publicar uma obra do gênero romance histórico foi João Manuel Pereira da Silva, entretanto sua obra não foi aceita pela crítica literária como a primeira narrativa do romance histórico brasileiro; sobre isso Alcmeno Bastos (2011, p.02) afirma: "Dos romances de Pereira da Silva não é adequado dizer-se que são romances históricos brasileiros. Nos dois casos, a ação não se passa no Brasil, mas em Portugal, e os protagonistas também são portugueses". Assim, sua obra não estaria qualificada como romance histórico brasileiro, considerando que seu texto possuía espaço narrativo europeu.

Antonio R. Esteves salienta que Antonio Candido "aponta como primeiro romance histórico brasileiro Um roubo na Pavuna, de Luís da Silva Alves de Azambuja (1791-1873), publicado em 1843" (ESTEVES, 2010, p. 26). Entretanto, outras narrativas cujas temáticas apresentavam a problemática histórica foram publicadas antes, "embora curtas, no limiar entre novela, romance e narrativa histórica, gêneros híbridos cuja zona fronteiriça é de difícil delimitação" (Idem, p. 26). Exemplo disso, são as obras Virginia, de João José de Souza, ou a Vingança de Nassau, de Silva Rio, publicadas em 1840. Dessa maneira, Antonio R. Esteves (2010) aponta uma obra que ele acredita se tratar de um romance histórico e que poderia ser a primeira obra brasileira do gênero, mas que a crítica literária não a considerou, como vemos:

Joaquim Norberto de Souza e Silva (1820-1861), importante historiador e crítico ligado ao Instituto Histórico e Geográfico Brasileiro, publicou, em 1841, Duas orfãs, que alguns críticos classificam como novela e outros como conto (Moisés, 1984, p.64). A ação também ocorre no tempo de Nassau, embora "nenhuma relação guarda com o pano de fundo histórico, salvo o fato de as duas órfãs lutarem bravamente contra os holandeses", segundo afirma Massaud Moisés em seu manual de literatura. Ora, segundo o modelo estabelecido por Scott, poderíamos dizer que o romance histórico do século XIX usa o momento histórico apenas como pano de fundo. Nesse caso, apesar de ser uma história de amor, há que considerar que as duas irmãs lutam contra o invasor estrangeiro, dentro de um pano de fundo bem de acordo com o momento de exaltação nacional construído por Norberto e seus confrades do Instituto Histórico (ESTEVES, 2010, p. 26).

O trecho acima acaba evidenciando como os parâmetros de classificação da crítica da época são questionáveis, principalmente em relação à escolha de qual 
obra seria a primeira narrativa do romance histórico brasileiro. Porém, o que é evidente na literatura brasileira é que muitos escritores se destacaram nesse gênero, como José de Alencar, que marcou a maturidade do romance brasileiro, seja histórico ou não histórico. Alencar foi um dos maiores seguidores de Scott na América. Ademais, em suas narrativas "consolida não apenas o ideal nacionalista por meio do indianismo, como também o romance histórico no Brasil, em obras como O Guarani (1857), As Minas de Prata (1862-6), Iracema (1865), Guerra dos Mascates (1871) e Ubirajara (1874)". Grandes nomes da literatura enfatizam seu desempenho como escritor, entre eles, está Antonio Candido.

Antonio Candido (1971, p.223), que vê em Alencar "o único escritor de nossa literatura a criar um mito heroico, o de Peri", aponta a riqueza da obra do escritor a partir da tentativa de superar uma série de desníveis e desarmonias que produzem em sua obra várias fissuras, que acabam sendo produtivas, construindo sua principal qualidade. A primeira dessas desarmonias é tentar conciliar, fascinado como Scott por castelos e cavaleiros, a curta e frágil história do novo país com uma ancestral tradição, que no fundo pretendia negar. Trata-se do desejo de submeter a realidade contraditória de um país de aventureiros escravistas que veem a exuberante natureza apenas como fonte de exploração e lucro fácil, à vontade de construir uma nação com fortes vínculos, também ambíguos, com a natureza e com a tradicional nobreza de caráter, também idealizada pelo romantismo, que não aceitava as mudanças trazidas pelos ventos da industrialização (ESTEVES, 2010, p.2 8-29).

José de Alencar é destacado como um grande romancista, pois suas narrativas possuíam características próprias, produtivas e qualificadas, que o destacavam como escritor. Ademais, quando analisamos suas obras de cunho histórico, percebemos sua dedicação à história nacional, como enfatizado:

Nessa medida, o projeto de criação do romance nacional de Alencar está orientado por seu objetivo de escrever a História presente e passada do Brasil, na linguagem que Ihe oferecia o Romantismo. Por isso seus romances podem ser vistos como ensaios (no lato senso da palavra), como tateios, como procura de uma maneira adequada para capturar a diversidade de cada momento de nossa vida. Devese destacar que esta concepção do autor quanto à necessária vinculação entre a História e o texto literário ganhou uma formulação sistemática em "Benção paterna" (1872), prefácio a Sonhos d'ouro. Neste texto, Alencar delineia sua ficção como um painel da Geografia e da História do Brasil. Para recriar o primeiro momento do mundo primitivo do selvagem, estariam as lendas, como Iracema. O retrato da convivência entre as duas raças que primeiramente formaram o país - o índio e o português - marcando a época colonial poderia ser encontrado em O Guarani e As Minas de Prata. O terceiro momento 
ter-se-ia inaugurado com a Independência e, para retratá-lo, Alencar estabelece dois caminhos, dois tipos de romance: a história da vida urbana, marcada pelas relações com idéias e hábitos estrangeiros (Lucíola, Diva, A Pata da Gazela, Sonhos D'ouro) e o retrato da vida rural (O Gaúcho, Til, O Tronco do Ipê). (MARCO, 2009, p.107)

Conforme a citação acima, notamos que o escritor era praticante da vertente do romance histórico de cunho nacional, pois sabe-se que o gênero no Brasil fez alguns caminhos distintos: regionalismo, indianismo (nestes são valorizados a natureza e o desejo de topografia do Romantismo) e o romance de costumes (neste há a preocupação com os hábitos socioculturais, culturais etc. dos habitantes das cidades, mas que também se apresenta nas obras regionalistas). Dessa maneira, o gênero sofre mudanças com seus seguidores pós Alencar. "Boa parte deles, no entanto, rompe com um dos pressupostos básicos apontados por Lukács para o modelo fixado por Scott: a ficcionalização de personagens históricos" (ESTEVES, 2010, p.32).

Ou seja, suas narrativas buscavam trabalhar com personagens históricos excluídos socialmente da história brasileira. Ademais, "E seguindo o parâmetro instaurado pelos sucessores de Alencar, muitos deles transferem a ação para as diversas regiões, seguindo os passos do regionalismo." (ESTEVES, 2010, p.32) Com isso, inúmeras narrativas trazem, para seu espaço ficcional, pequenos vilarejos e cidades. Assim, essas mudanças começam a ser notadas nas obras de novos escritores do gênero, exemplo disso, foi uma matéria do crítico austríaco Otto Maria Carpeaux, publicada em 1958, no Jornal O Estado de S. Paulo na qual em forma de ensaio dialogava sobre o romance João Abade, de João Felício dos Santos, e, ao mesmo tempo, sobre o romance histórico.

Chama a atenção, nesse ensaio, a lucidez do crítico austríaco sobre o gênero, que, segundo muitos historiadores da literatura, começava a assimilar importantes modificações, advindas não apenas da mudança da concepção da história ocorrida ao longo da primeira metade do século, mas também da forma de se encarar o próprio gênero romance, ocorrida na transição do século XIX para o XX, especialmente após as vanguardas. Embora o crítico apresente praticamente o mesmo panorama do romance histórico que inclui no capítulo de sua História da literatura ocidental ao tratar de Scott e da fundação do gênero, aponta para as características do gênero que predominariam na segunda metade do século XX. A principal delas aparece no romance de João Felício dos Santos: "O autêntico romance histórico realiza uma 'revisão de valores', ressuscitando os vencidos, dando uma voz aos que a História, essa fable convenue, silenciou" (ESTEVES, 2010, p. 32). 
Com as transformações do romance histórico, destacam-se outros nomes da literatura, que compõem um novo cenário do gênero, como João Felício dos Santos, que abordava em suas narrativas dados historiográficos de pessoas históricas excluídas ou pouco retratadas na história brasileira. Assim, todas as suas obras possuíam o mesmo objetivo "trazer para o centro das discussões, por meio da literatura, momentos históricos ou personagens históricos que a história convencional, ou hegemônica, fez questão de ignorar e, em muitos casos, até mesmo de silenciar" (ESTEVES, 2010, p. 32).

Da mesma maneira, Antonio R. Esteves, apresenta o escritor Agripa Vasconcelos, que se encaixava nesse mesmo contexto do gênero. Apesar de suas narrativas apresentarem traços "dos velhos cânones alencarianos, como as descrições de ambientes locais, o escritor mineiro traçou em vários romances um interessante painel da história de seu Estado" (ESTEVES, 2010, p. 32). Ele acabou "trazendo para o centro da ação personagens como Xica da Silva, Chico Rei, dona Beija, ou outros excluídos sociais, raciais ou de gênero" (Idem, p. 32). Essa última característica do trabalho de Agripa Vasconcelos se assemelha ao trabalho de João Felício dos Santos, direcionando a possibilidade de os dois escritores terem trabalhado o gênero em um contexto literário comum.

Portanto, apesar da evidente relação do romance histórico brasileiro com o romance histórico tradicional de Scott, o gênero aderiu novas particularidades e perspectivas no processo de ficcionalização da história brasileira. Dessa maneira, os escritores procuravam trazer para o centro narrativo, eventos e pessoas ignoradas ao retratarem a história brasileira. Resultando, por meio disso, um modelo com raízes scottianas, mas com características tipicamente brasileiras, evidenciando a dedicação dos precursores brasileiros.

As evidentes transformações do romance histórico são notadas na virada no final do século $X X$, havendo um aumento em sua procura por escritores nesse período, o que, segundo Marilene Weinhardt (1995, p. 54), estaria relacionado com a volta de reflexões em relação à constituição identitária. Assim, esse momento é nomeado de romance histórico contemporâneo ou novo romance histórico, e ocorre entre 1980 e 1990. Porém, a finalidade de suas obras se desvincula das do romance histórico tradicional. Em vista disso, Seymor Menton (1993) elenca seis 
características que diferenciam o novo romance histórico do romance histórico tradicional. São elas:

1 - a subordinação, em distintos graus, da reprodução mimética de certo período histórico à apresentação de algumas idéias filosóficas, difundidas nos contos de Jorge Luis Borges e aplicáveis a todos os períodos do passado, do presente e do futuro, destacando-se as idéias da impossibilidade de se conhecer a verdade histórica, do caráter cíclico da história e o caráter imprevisível que ela possui, fazendo com que os acontecimentos mais inesperados e assombrosos possam ocorrer;

2 - a distorção consciente da história, mediante omissões, anacronismos e exageros;

3 - a ficcionalização de personagens históricos, ao contrário da fórmula de Walter Scott, aprovada por Luckacs, que se utilizava de personagens fictícios como protagonistas;

4 - a metaficção ou comentários do narrador sobre o processo de criação;

5 - a intertextualidade;

6 - os conceitos bakhtinianos de dialogia, carnavalização, paródia e heteroglasia (MENTON, 1993, p. 42- 46).

As modificações entre os dois momentos do gênero são marcantes e evidentes, principalmente, no que se refere à representação dos indivíduos sociais na narrativa, pois percebe-se um grande movimento em torno de apresentar indivíduos pertencentes aos grupos marginais da sociedade, como mulheres, negros e as pessoas LGTBQI+. Desse modo, enriqueceu-se o gênero ao abrir espaço para essas novas vozes na literatura. Além disso, ressalta-se que a obra não precisa necessariamente apresentar todas as características para qualificar-se como romance histórico contemporâneo. Assim, de maneira geral, para Antônio R. Esteves, a nova forma do gênero se destaca porque:

Adota uma atitude crítica ante a história: ele reinterpreta o fato histórico, usando para isso de todas as técnicas que o gênero narrativo dispõe. Para isso usa uma série de artimanhas ficcionais: inventa situações fantásticas; distorce conscientemente os fatos históricos; coloca lado a lado personagens históricos e ficcionais; rompe com as formas convencionais de tempo e de espaço; alterna focos narrativos e momentos de narração; e especialmente se vale, às vezes até de modo exagerado, da intertextualidade em suas diferentes formas de manifestação, sobretudo a paródia e a forma carnavalizada de ver o mundo (ESTEVES, 2010, p. 36).

Desse modo, os escritores do gênero no final do século $X X$ irão propor uma revisão crítica da história, apresentando argumentos cruciais sobre certos momentos históricos, como o escritor João Ubaldo Ribeiro que se destacou nesse período 
questionando o protagonismo da formação da cultura brasileira para os vencidos, por meio de sua obra Viva o povo brasileiro (1984).

Desse ponto de vista, João Ubaldo Ribeiro, escritor baiano, que
envolvia em seus enredos temas sociais com engajamento político e
por meio de uma linguagem neo-barroca, representa em Viva o povo
brasileiro fatos que abarcam trezentos e trinta anos da História do
Brasil, na tentativa de polemizar e desmitificar episódios que
marcaram o país. É a partir desse aspecto que se estabelece a inter-
relação entre literatura e história, além de demonstrar uma das
importantes funções do poder da representação: facilitar a
compreensão dos acontecimentos durante a trajetória histórica do
Brasil. A narrativa apresenta o processo histórico da construção do
país, exposição capaz de modificar nossa concepção do passado
através dos fatos selecionados e representados pelo romance
(ANDRADE; SILVA, 2015, p.108).

A obra de Ribeiro é uma das narrativas do romance histórico contemporâneo que busca romper a totalidade das grandes narrativas e por meio de sua forma fragmentada procura evidenciar os fatos históricos. Entretanto, outras obras se destacaram nesse segundo momento do gênero, entre elas estão: Galvez imperador do Acre (1976), Mad Maria (1978) e O primeiro brasileiro (1986), do amazonense Márcio Souza; Em liberdade (1981), do mineiro Silviano Santiago; A casca da serpente (1989), do goiano José J. Veiga e Memorial do fim (A morte de Machado de Assis) (1991), do paraense Haroldo Maranhão.

Enfim, é possível notarmos que o gênero romance histórico, seja tradicional ou contemporâneo, está relacionado a uma busca pelo passado como forma de entender o presente, e, como gênero literário é sofreu constantes transformações no decorrer do tempo, porém jamais fugiu de sua essência em trabalhar com algo histórico, sejam fatos ou pessoas.

\subsection{CONSIDERAÇÕES SOBRE O ROMANCE HISTÓRICO}

O romance é um espaço de criação ao mesmo tempo em que busca representar algo do mundo real de um determinado ponto de vista, traz configurado dentro de si um recorte temporal ou espacial de maior ou menor abrangência. Como vemos:

Segundo Mikhail Bakhtin (1990, p.110), o romance é um gênero híbrido. Híbrido porque nele duas vozes caminham juntas e lutam no território do discurso. Dois pontos de vista que não se misturam, mas 
se cruzam dialogicamente. Essa construção híbrida tem uma importância capital para o romance, uma vez que "pertence a um único falante, mas onde, na realidade, estão confundidos dois enunciados, dois modos de falar, dois estilos, duas "linguagens", duas perspectivas semânticas e axiológicas" (ESTEVES, 2010, p.19).

Dessa maneira, notamos que ele é hibrido e único em relação aos outros gêneros narrativos, pois ao representar pessoas comuns em seus sentimentos e dilemas, ele acaba constituindo uma espécie de reflexo da sociedade, resultando em um meio de "fuga" da realidade. Entretanto, nesta pesquisa entendemos o romance histórico:

Muito mais que o romance tout court, o que chamamos de romance histórico é um gênero narrativo híbrido, surgido de um processo de combinação entre história e ficção. Trata-se de um gênero bastardo e ambíguo, de acordo com o crítico espanhol García Gual (2002, p.11). E embora desperte mais interesse no homem contemporâneo que quaisquer outras formas mais objetivas de linguagem, não se deve esquecer de que o substantivo nessa expressão é o romance. Assim, por mais que ele se sustente em fatos ou personagens históricos, trata-se de romance, ou seja, de ficção (ESTEVES, 2010, p. 20).

Assim, notamos que o romance histórico é hibrido, ou seja, ele é resultado da relação entre história e ficção, tornando-se um processo combinatório e único entre os demais gêneros narrativos. Assim, entendemos que ele é um gênero ao invés de subgênero, pois não se trata de uma categoria taxonômica de qualidade inferior ao romance, mas de um produto original e de mesma valia para a literatura.

Dessa maneira, Carlos Alexandre Baumgarten (2016) observa as marcas essenciais do romance histórico tradicional, apontadas pelo trabalho de Gyorgy Lukács:

a - traçam grandes painéis históricos, abarcando determinada época e um conjunto de acontecimentos;

b - a exemplo dos procedimentos típicos da escrita da História, organizam-se em observância a uma temporalidade cronológica dos acontecimentos narrados;

c - valem-se de personagens fictícias, puramente inventadas, na análise que empreendem dos acontecimentos históricos;

d - as personalidades históricas, quando presentes, são apenas citadas ou integram o pano de fundo das narrativas;

e - os dados e detalhes históricos são utilizados com o intuito de conferir veracidade à narrativa, aspecto que torna a História incontestável;

f - o narrador se faz presente, em geral, na terceira pessoa do discurso, numa simulação de distanciamento e imparcialidade, 
procedimento herdado igualmente do discurso da História (BAUMGARTEN, 2016, p. 108).

Nesse sentido, o romance histórico tradicional, conforme o modelo scottiano, possui como tempo narrativo o passado anterior à época do escritor, entrelaçandose história e ficção, e descrevendo a experiência da vida de uma determinada sociedade. Ademais, "o romance não comporta heróis, no sentido clássico, mas seres humanos, igualmente capazes de atos heróicos determinados por motivos vis e de ações condenáveis movidas por sentimentos nobres." (WEINHARDT, 1994, p. 50). Por mais que ele sustente, porém, personagens ou/e fatos históricos, ressaltase que se trata de uma ficção e não de uma transcrição do real.

No romance histórico, portanto, não se trata do relatar contínuo dos grandes acontecimentos históricos, mas do despertar ficcional dos homens que os protagonizaram. Trata-se de figurar de modo vivo as motivações sociais e humanas a partir das quais os homens pensaram, sentiram e agiram de maneira precisa, retratando como isso ocorreu na realidade histórica (LUKÁCS, 2011, p. 60).

Nesse caso, por meio dos romances trabalhados por esta análise, teríamos um contato com indivíduos e fatos do período colonial brasileiro, demarcados em seus aspectos sociais, culturais e políticos, de diferentes pontos de vista, como vemos:

Em sua eterna tentativa de captar e entender o passado, o ser humano se vale da linguagem. $E$ a linguagem, como se sabe, por um lado, tem regras fixas, preestabelecidas, e limita as possibilidades do falante; por outro, no entanto, flui sem cessar ao longo do tempo, fazendo que a experiência de uma geração seja diferente da outra. Então, por mais objetividade que tenhamos, estamos sempre fazendo uma releitura dos fatos que, para serem transmitidos, sofrerão uma interpretação de acordo com nossos pontos de vista; dentro de nosso espaço; de acordo com a visão de nosso tempo. A partir da segunda metade do século $X X$, é quase consenso generalizado que a história e a literatura têm algo em comum: ambas são constituídas de material discursivo, permeado pela organização subjetiva da realidade feita por cada falante, o que produz infinita proliferação de discursos (ESTEVES, 2010, p. 13).

O romance histórico aponta, muitas vezes, a existência de diferentes visões dos eventos históricos registrados, tornando possível uma multiplicidade de possibilidades de versões e interpretações desses acontecimentos. Assim, desmistifica-se que o objetivo desse gênero seria representar a realidade histórica pelo viés da imitação, como Marilene Weinhardt ressalta: 
(...) Ao romance histórico não interessa repetir o relato dos grandes acontecimentos, mas ressuscitar poeticamente os seres humanos que viveram essa experiência. Ele deve fazer com que o leitor apreenda as razões sociais e humanas que fizeram com que os homens daquele tempo e daquele espaço pensassem, sentissem e agissem da forma como o fizeram. Trata-se de uma norma da figuração literária, aparentemente paradoxal, que se alcance esta apreensão focalizando os detalhes do quotidiano que parecem insignificantes. Os grandes dramas e as figuras históricas centrais são próprios para a epopéia. O mundo do romance é o da esfera popular. Esta, tensionada pela revolução, pode revelar suas forças, surgindo naturalmente os heróis que para a história são incógnitos (WEINHARDT, 1994, p. 51).

Essas particularidades da narrativa que Marilene Weinhardt (1994) cita são observáveis nas obras de João Felício dos Santos, Agripa Vasconcelos e Joyce Ribeiro, ao trabalharem em suas narrativas com a pessoa histórica de Francisca da Silva Oliveira, pois o enfoque histórico está na vida cotidiana das personagens, expressado através de seu modo de vestir, de se comportar, de pensar e de sentir, coerentes com o século XVIII. Quando se trata da personagem principal Chica da Silva, a narrativa apresenta o seu dia a dia como esposa do contratador e como a sociedade a trata e a vê ocupando o lugar que julga pertencer a uma mulher branca, pelo pensamento do período colonial.

A partir dessa constatação, observa-se de que maneira a personagem quebra um grande paradigma social, cultural e político da época, mostrando que sua cor não a torna impossibilitada de ocupar essa posição social que lhe é outorgada pelo casamento com um homem da elite branca.

O romance histórico tem como objetivo ficcionalizar dados históricos, criando, dessa maneira, diferentes "mundos" que buscam retratar tais fatos. Sendo assim, Esteves ressalta:

Não se trata, entretanto, de substituir a história pela ficção, mas de possibilitar uma aproximação poética em que todos os pontos de vista, contraditórios mas convergentes, estejam presentes, formando o que Steenmeijer (1991, p.25) chama de representação totalizadora. Segundo este último ponto de vista, e usamos aqui a feliz expressão de Heloísa Costa Milton (1992), a literatura pode ser considerada uma leitora privilegiada dos signos da história (ESTEVES, 2010, p. 13).

O escritor evidencia que esse tipo de obra não busca ficcionalizar totalmente os fatos históricos, mas apontar possíveis leituras interpretativas deles por meio da 
ficção. Considerando que pessoas de diferentes esferas sociais podem possuir interpretações diferentes para um mesmo fato, é evidente que eles irão se diferenciar em seus argumentos e descrições. Portanto, o que a literatura se propõe a fazer é apresentar uma leitura sobre signos históricos de um determinado fato escolhido, ou seja, no caso de Chica da Silva, entender como o Contratador João Fernandes de Oliveira se interessa justamente por ela, e não por outra mulher, preferencialmente para os padrões da época, branca.

O esquema do romance histórico criado por Scott, que acabou por se impor como modelo, obedece a dois princípios. O primeiro deles é que a ação ocorre em um passado anterior ao presente do escritor, tendo como pano de fundo um ambiente rigorosamente reconstruído, onde figuras históricas ajudam a fixar a época. Sobre esse pano de fundo situa-se uma trama fictícia, com personagens e fatos inventados pelo autor. Além disso, como segundo princípio, os romances de Scott e seus seguidores, bem ao gosto romântico, costumam introduzir na trama ficcional um episódio amoroso geralmente problemático, cujo desenlace pode variar, ainda que, na maioria das vezes, termine na esfera do trágico (ESTEVES, 2010, p.19).

Os princípios citados acima configuram o romance histórico tradicional e são observáveis nas obras utilizadas neste trabalho. Os escritores retratam o século XVIII, nas Minas Gerais, porém escrevem em uma época posterior ao desenlace do enredo, Vasconcelos em 1966, Santos em 1976 e Ribeiro em 2016. Em partes, também se percebe o segundo princípio, o gosto romântico presente nas obras, muitas vezes entremeados de lances de caráter naturalista, como se vê em Agripa Vasconcelos. As três obras trabalham com a problemática amorosa, envolvendo o relacionamento de Chica da Silva com o contratador de diamantes João Fernandes de Oliveira, e terminam de forma trágica, com o casal sofrendo uma separação imposta a eles devido a prisão do contratador em Portugal. Sobretudo, ressalta-se que as informações apresentadas nas narrativas em relação a pessoa de Francisca da Silva Oliveira são misto de dados históricos e ficcionais:

Sabe-se também que, na maioria das vezes, fica bastante difícil separar o que realmente aconteceu do que poderia ter acontecido. Depois de certo tempo a memória falha. O ser humano passa a misturar o que realmente aconteceu com o que pensa ter acontecido; ou com aquilo que desejaria que tivesse ocorrido ou, sobretudo, com o que convém que se pense que aconteceu. Então as coisas se embaralham e é praticamente impossível determinar o que 
"realmente" aconteceu. O que é fictício? O que é histórico? Difícil saber (ESTEVES, 2010, p.13-14).

Dessa maneira, os fatos acontecidos e ficcionalizados na narrativa do romance histórico se tornam algo único e inseparável, não sendo possível distinguir quais dados pertencem a cada categoria, ou seja, quais são dados históricos e ficcionais. Ademais, entre as preocupações dos precursores do gênero está a busca pelo equilíbrio entre "a fantasia e a realidade, configurando-se como espaço discursivo em que os jogos inventivos do escritor, aplicados a dados históricos, produzissem composições que oferecessem aos leitores" (ESTEVES, 2010, p.19). Dessa forma, as obras do romance histórico buscam construir uma ilusão do mundo real e, ao mesmo tempo, oferecer um meio de fuga de uma realidade insatisfatória.

Vejamos duas delas, muitas vezes tidas como excludentes. Ou a
história, como a ficção, com seu discurso narrativamente organizado
pelo ponto de vista do historiador, também é uma invenção; ou então
pode-se chegar à verdade histórica por meio da literatura, discurso
tradicionalmente tido como fruto da criatividade de um escritor
historicamente localizado em um determinado tempo e espaço a
partir do qual enuncia (ESTEVES, 2010, p.13).

De modo algum a ficção procura ocupar o papel da história, ou desvalorizar seus discursos, cada área possui objetivos específicos ao trabalhar com o material em questão. Portanto, suas narrativas possuem caminhos distintos, pois na ficção é de suma importância o pacto fictício feito com o leitor para a construção de sua credibilidade.

Ao abrir as portas do mundo da fantasia, e nós leitores sabemos disso; ao iniciar a leitura de um romance, estabelece-se o pacto fictício, o romancista nos introduz nesse mundo enfeitiçado onde todos encontramos os fantasmas que necessitamos alimentar para podermos viver. E essa é a verdade que expressam as mentiras da ficção: as mentiras que somos; que nos consolam e nos salvam de nossas nostalgias e frustrações. A ficção é um sucedâneo transitório da vida. O retorno à realidade sempre sofre um empobrecimento brutal: a comprovação de que somos muito menos do que sonhamos. As mentiras dos romances, então, nunca são gratuitas: preenchem as insuficiências da vida. (LLOSA, Apud ESTEVES, 2010, p.14)

As narrativas não contam mentiras, mas criam suas próprias verdades, pois como leitores quando aceitamos o pacto fictício adentramos em seu universo, 0 vivemos e compartilhamos dos sentimentos de suas personagens. Nesse universo 
ficcional constroem-se suas próprias verdades, porém elas são relativamente ambíguas, como vemos:

A literatura, enfim, trabalha o reino da ambiguidade. Suas verdades são sempre subjetivas: verdades pela metade, verdades relativas que nem sempre estão de acordo com a história. Nesse sentido, a recomposição do passado que a literatura faz é quase sempre falsa, se a julgamos em termos de objetividade histórica. Não há dúvidas de que a verdade literária é uma e a verdade histórica é outra. No entanto, embora recheada de mentiras - e talvez por isso mesmo -, a literatura conta histórias que a história escrita pelos historiadores não sabe, não quer ou não pode contar. Os exageros da literatura servem para expressar verdades profundas e inquietantes que só dessa forma poderiam vir à luz (ESTEVES, 2010, p.14).

Dessa maneira, a verdade da literatura é subjetiva, pois não são verdades do mundo real, são pertencentes ao mundo imaginário. A literatura ao trabalhar com dados históricos não possui o mesmo objetivo da história, sua intenção vai além de descrever o mundo real: o de criar um novo e único mundo, o ficcional. A obra literária não é construída sobre a base da mentira, e sim da imaginação, e, por meio do pacto ficcional com os leitores, ela cria sua própria forma de verossimilhança.

Enfim, a obra do romance histórico tem a finalidade de apresentar respostas para lacunas da história, porém, suas respostas são ficcionais, trabalhadas de forma tão minuciosa que ao fim seu leitor não a distingue como pertencente ao real ou ficcional, constituindo seu maior objetivo, de construir suas próprias verdades.

\subsection{A IMPORTÂNCIA DOS ESTUDOS COMPARATIVOS EM ROMANCES HISTÓRICOS}

A literatura comparada é uma espécie de investigação literária entre duas ou mais obras, com intuito de desvendar as ligações entre elas. Seu surgimento, segundo Carvalhal (2006, p. 08) está vinculado à corrente de pensamento cosmopolita que caracterizou o século XIX, época em que comparar estruturas ou fenômenos análogos, com a finalidade de extrair leis gerais, foi dominante nas ciências naturais.

Não há um formula especifica de como fazer para aplicar a literatura comparada; existem diferentes métodos, cada qual com seus procedimentos, mas todos com a mesma finalidade, de analisar objetos entre si. 
A literatura comparada compara não pelo procedimento em si, mas porque, como recurso analítico e interpretativo, a comparação possibilita a esse tipo de estudo literário uma exploração adequada de seus campos de trabalho e o alcance dos objetivos a que se propõe (CARVALHAL, 2006, p. 07).

É no início do século XX que a literatura comparada torna-se uma disciplina reconhecida, sendo um dos objetos de ensino regular em grandes universidades europeias e norte-americanas. Nos estudos considerados clássicos sobre este tema, está o primeiro número da Revue de Littérature Comparée, criada em 1921 por Fernand Baldensperger e Paul Hazar. Nesta época os estudos comparados seguiam duas orientações básicas. A primeira de que a validade das comparações literárias dependia se realmente existia um contato real e comprovado entre as obras ou/e autores.

A identificação de tais contatos abria caminho para os estudos de fontes e de influências; com isso, as investigações que se ocupavam em estabelecer filiações e em determinar imitações ou empréstimos recebiam grande impulso (CARVALHAL, 2006, p. 13).

A segunda orientação determinava que houvesse uma definitiva vinculação dos estudos literários comparados com a perspectiva histórica. Assim a literatura comparada se torna um dos ramos da história literária.

Tal vinculação se deve ao fato de a nova disciplina ter atraído de pronto a atenção de historiadores literários, como Ferdinand Brunetièr. Este, ao ministrar um curso de literatura comparada $\mathrm{cm}$ 1890-1891, lança os pressupostos de uma história dos grandes movimentos literários no mundo ocidental com base na comparação entre eles (CARVALHAL, 2009, p.13).

No texto A crise da literatura comparada, de Wellek (1994), ele debate sobre as fragilidades teóricas da disciplina e sua incapacidade de estabelecer um objeto de estudo distinto e uma metodologia específica, algo que havia sido discutido negativamente por alguns críticos, como F. Baldensperger e J-M. Carré. Wellek não fez propostas específicas para a literatura comparada, mas ele propôs que esta disciplina deveria assumir uma perspectiva de crítica literária.

Um dos mais reconhecidos estudiosos desse ramo foi o tcheco Dionyz Durisin, que formulou uma proposição metodológica considerada por muitos como um "modelo" inovador. Tal metodologia era apoiada nos princípios do estruturalismo de Praga. Pierre Swiggers (apud CARVALHAL, 2009, p. 40), por exemplo, classifica 
essa contribuição como "novo paradigma" nos estudos comparados, em oposição às propostas mais tradicionais.

Durisin buscava estabelecer classificações tipológicas mediante aos estudos comparados, por meio desta preocupação, oferece uma tipologia sistemática das relações literárias. Tendo como finalidade organizar estas relações literárias, ele as distingue entre contatos genéticos e relações de solidariedade tipológica.

O estudo dos primeiros está subdividido em análise de contatos externos (ou primários), como, por exemplo, o sucesso literário, e em contatos internos (os casos de influências). Esses contatos em seu aspecto material, podem ser diretos ou indiretos. Por outro lado, as relações de solidariedade tipológica são diferenciadas de acordo com o pano de fundo social, literário ou psicológico, que frequentemente tem uma função normativa. As distinções entre essas relações são feitas por condições impostas pelas escolas ou correntes literárias, pelos gêneros ou pelo modelo de um trabalho literário (DURISIN, apud CARVALHAL, 2009, p. 41).

Esta metodologia de Durisin é reconhecida por eliminar o conceito de influência no sentido clássico, substituindo-o pelo conceito operacional de estratégia de influência. Fazendo isso, o estudioso acabou distinguindo as estratégias integradoras (que seriam a imitação, a adaptação, o empréstimo) das estratégias diferenciadoras (a paródia, a sátira, a caricatura). Percebe-se que o objetivo de Durisin era propor uma metodologia na qual houvesse uma espécie de comprovação por intermédio de explicações estruturais para os fenômenos literários.

O que interessa em sua reflexão é que, através de um modelo hipotético dedutivo, ele investiga as relações que são estabelecidas não apenas entre autores e obras, mas entre sistemas e subsistemas literários, governados por certas normas e tendências (estéticas, sociais e políticas) (CARVALHAL, 2009, p. 41).

$\mathrm{Na}$ literatura comparada, todo texto literário é analisado dentro do seu contexto social, político e estético. Não é possível analisarmos uma obra por meio deste método de forma isolada, sem considerar o contexto em que a obra está inserida, pois a função do texto acontece mediante dessa correlação com o extraliterário.

É possível o estudo chamado "imanente" da obra enquanto sistema, ignorando suas correlações com o sistema literário? (...) Entretanto, mesmo a literatura contemporânea não pode ser estudada isoladamente. A existência de um fato como fato literário depende de sua qualidade diferencial (isto é, de sua correlação seja com a série 
literária, seja com uma série extraliterária), em outros termos, de sua função (TYNIANOV, apud CARVALHAL, 2009, p. 47).

Por meio do questionamento e estudos de Tynianov, percebemos que quando um elemento é retirado de seu contexto original, ele passa a integrar outro contexto e já não pode ser considerado idêntico ao primeiro, pois a sua inserção altera sua própria natureza, e acaba exercendo outra função. Enfatiza-se mediante aos estudos de Tynianov, também, que a constituição de uma obra literária se faz como uma rede de "relações diferenciais", por intermédio dos textos literários que a antecedem e dos sistemas não-literários.

O conhecimento da Literatura Comparada ensinou-nos, entre outras coisas, a conceber o fenômeno literário como um fenômeno de cultura, a nunca esquecer que um texto literário é uma forma especial de comunicação e, consequentemente, de simbolização do mundo. Em suma: a nunca dissociar "literariedade" e contexto cultural, mesmo social, dado que o fenômeno literário é também um processo de socialização, pela própria existência do público leitor, das relações entre produção literária e realidades sociais (JAUSS, 1994, p.166).

As obras literárias são o reflexo das transformações sociais também, pois muitas trazem, em suas linhas, representações de uma sociedade, em um determinado espaço e tempo. Tais obras narram fatos ocorridos na sociedade, como, por exemplo, o caso de Auschwitz com os judeus, fato contado e recontado em inúmeras obras. Não se pode pensar uma obra literária como algo único a ser analisado, pois são muitos os intertextos e os diálogos por detrás da produção delas.

O conceito de influência tem duas acepções diferentes. A primeira, a
mais corrente, é a que indica a soma de relações de contato de
qualquer espécie, que se pode estabelecer entre um emissor e um
receptor. A segunda acepção é de ordem qualitativa. Influência é o
"resultado artístico autônomo de uma relação de contato",
entendendo-se por contato o conhecimento direto ou indireto de uma
fonte por um autor (NITRINI, 1997, p.127).

Outro fator que tem relevância é a construção literária do autor, pois é por meio de suas leituras e conhecimento da produção de outros escritores que ele vai se moldando, criando seu próprio estilo de criação literária, porém esta atitude é vista como influência, pois sua obra resulta do conhecimento de outra. Para Aldridge (apud NITRINI, 1997, p.128), a influência se define como "algo que existe na obra de um autor que não poderia ter existido se ele não tivesse lido a obra de um autor que o precedeu". 
Costuma-se confundir muito o termo influência com o termo imitação. O que diferencia as duas noções é que a imitação se refere a detalhes materiais como traços de composição, episódios, procedimentos, ou topos bem determinados, enquanto a influência é a presença de uma transmissão menos material, resultante da visão artística e ideológica do receptor.

A imitação é um contato localizado e circunscrito, enquanto a influência é uma aquisição fundamental que modifica a própria personalidade artística do escritor. A influência distingue-se da tradução que se identifica a si mesma, e da imitação, que se reconhece por um simples cotejo de textos (NITRINI, 1997, p.127).

Um dos questionamentos em relação ao tema é a questão da originalidade de uma obra, já que o autor teve como influência outras obras e autores. Porém este processo não impossibilita que uma obra seja considerada original, pois cada obra é uma nova assimilação de um assunto específico. "Nada mais original, nada mais próprio do que nutrir-se dos outros. Mas é preciso digeri-los. O leão é feito de carneiro assimilado" (VALERY, apud NITRINI, 1997, p.128).

Percebemos que uma obra tem originalidade quando, mesmo tendo como inspiração outras obras, o escritor retira delas a essência e as transforma em uma obra completamente original, a qual sabemos ser única. Deste modo, seria um insulto dizermos que tal situação se configura como plágio. Segundo Valéry (apud NITRINI, 1997, p.129), plagiário é aquele que digeriu mal a substância dos outros: torna seus pedaços reconhecíveis.

A originalidade é assegurada, também, pela escolha feita pelo autor exposto a uma influência. A maior originalidade é garantida quando uma obra age sobre o escritor, não por todas as suas qualidades, mas apenas por algumas delas. No entanto, o apoio vindo de fora a um escritor é independente da qualidade do modelo. Uma obra secundária e mesmo medíocre pode esclarecer o escritor no caminho a ser trilhado e conduzi-lo à própria identidade (NITRINI, 1997, p.135).

Ao falarmos sobre literatura comparada, não podemos deixar de comentar sobre a teoria da intertextualidade, que surgiu a partir da segunda metade do século $\mathrm{XX}$, concebida pela estudiosa Julia Kristeva, que impulsionou o estudo dos conceitos de "fonte" e "influência". Esta pesquisadora se debruça sobre as reflexões e preposições de Mikhail Bakhtin. 
A intertextualidade se insere numa teoria totalizante do texto, englobando suas relações com o sujeito, o inconsciente e a ideologia, numa perspectiva semiótica. Julia Kristeva identifica completamente sujeito e processos semióticos que aí se articulam é explicar como se constitui o "sujeito" ou a sua ausência (NITRINI, 1997, p.158).

Para entendermos melhor o conceito de intertextualidade de Kristeva, precisamos saber que mediante seus estudos ela chega a uma concepção "paragramática" da linguagem poética, que implica em algumas teses: a linguagem poética é a única infinidade do código; o texto literário é um duplo: escritura-leitura; o texto literário é uma rede de conexões. Enfim, a linguagem poética surge como um diálogo entre textos, no qual sua sequência está duplamente orientada para o ato da reminiscência (evocação de uma outra escrita) e para o ato da somação (a transformação dessa escritura). Assim, o texto literário representa um sistema de conexões múltiplas e, dessa forma, é por meio de muito estudo que a autora elabora o seu conceito de intertextualidade.

O termo intertextualidade designa esta transposição de um ou vários sistemas de signos num outro, mas já que este termo foi frequentemente entendido no sentido banal de "crítica das fontes" de um texto, preferimos o de "transposição" que tem a vantagem de precisar que a passagem de um sistema significante a outro exige uma nova articulação da temática existencial, da posição enunciativa e denotativa (KRISTEVA, apud NITRINI, 1997, p.131).

Mediante deste conceito de intertextualidade chegamos a três conclusões: que há o reconhecimento da presença de outros textos em toda e qualquer obra literária; que, do mesmo modo, existe a existência de um trabalho de modificação que os textos estranhos sofrem ao serem assimilados e que o sentido unificador que deve ter o intertexto é entendido como texto absorvendo uma multiplicidade de textos, mas ficando unificado por um sentido.

Há, portanto, três elementos em jogo: o intertexto (o novo texto), o enunciado estranho que foi incorporado e o texto de onde este último foi extraído. $E$ há dois tipos de relações a considerar na problemática intertextual: as relações a considerar na problemática intertextual: as relações que ligam o texto de origem ao elemento que foi retirado, mas já agora modificado no novo contexto, e as relações que unem este elemento transformando ao novo texto, ao texto que o assimilou. Assim, a análise de uma obra literária buscará inicialmente avaliar as semelhanças que persistem entre o enunciado transformador e o seu lugar de origem e, em segundo lugar, ver de que modo o intertexto absorveu o material do qual se apropriou (NITRINI, 1997, p.164). 
Enfim, a literatura comparada não é apenas colocar dois textos a par um do outro e simplesmente compará-los, de forma a analisar apenas o que está escrito, ou seja, do conteúdo literário. Comparar é, também, considerar todo o contexto no qual uma obra está inserida e para quem ela é direcionada. É por meio de um olhar atento que se consegue notar as presenças literárias que pode haver dentro de um texto, além de mostrar que é comum, e até mesmo um fenômeno natural, que um texto mantém relações intertextuais com outro e que isso só mostra o crescimento e construção de um escritor.

Dessa maneira, acredita-se que a realização de análises comparativas em romances históricos é enriquecedora para a área de estudos literários, pois essas obras trabalham com dados históricos sobre pessoas e/ou acontecimentos, porém, como é feito seu uso no momento da ficcionalização, está atrelado ao seu adepto, ou seja, ao escritor que a lê e interpreta.

Assim, subentende-se que ao tratar de informações sobre o mundo real, essas podem ser interpretadas de inúmeras maneiras e por pessoas de diferentes tempos e pensamentos. Considerando essa possibilidade, quando analisamos algumas obras que buscam retratar o mesmo dado histórico, podemos perceber semelhanças e discrepâncias entre elas, tornando-as, portanto, objetos importantes para a realização de análises comparativas.

As artes do tempo, apesar disso, são uma tentativa de apreensão do tempo. De maneira mais abstrata na música, de maneira mais voltada aos acontecimentos e conteúdos na literatura. Ao criarem um tempo próprio, as obras de arte "temporais" também permitem remeter-se a um tempo passado, apreendido e vivido pelas pessoas em outros momentos (SOETHE, 2009, p.160).

O estudioso Paulo Astor Soethe (2009) evidencia que as artes do tempo, ou seja, as que trabalham com um determinado tempo histórico do qual o escritor não faz parte no momento de escrita criam seu próprio tempo na narrativa, pois esse tempo passado retratado especificamente na narrativa literária, reflete a apreensão de um determinado sujeito sobre o objeto a ser descrito. "Dessa forma o leitor tem diante de si personagens envolvidas em debates que reconstroem 0 ambiente intelectual do período imediatamente" (SOETHE, 2009, p.160) Assim, o leitor tem contato com um período, fato e indivíduos históricos do qual ele não faz parte, possuindo apenas as informações fornecidas pelo escritor a respeito do tema. 
Considerando que os dados históricos são descritos ao leitor conforme as intenções do escritor, é possível que outros escritores possuam argumentos e construções diferentes entre si, como no caso do objeto de análise deste trabalho em que as obras procuram revelar a história da ex-escrava Francisca da Silva.

Todavia, cada escritor a descreve por meio de perspectivas diferentes, pois cada um possui diferentes construções ideológicas e próprias do seu tempo de vivência. Dessa maneira, as narrativas do gênero romance histórico se tornam um meio de partilha de um tempo, narrado e de escrita, "a narrativa torna-se uma forma efetiva e adequada de abordar experiências coletivas no discurso, em uma comunidade de comunicação" (SOETHE, 2009, p.160). Assim, esse tipo de narrativa valoriza o meio literário como "experiência de partilha humana, de renovação das vivências de experiências que ainda marcam, no presente da partilha, as vidas de cada um" (Idem, p.160).

O escritor do romance histórico procura evocar acontecimentos sociais de uma determinada época, e que de alguma forma possua impacto na sociedade atual do qual faz parte. Assim, ele apresenta fatos vividos da história, re-criando impressões pessoais e coletivas sobre os eventos ocorridos.

Pois assim se concretiza a memória, lembranças individuais são partilhadas e recebem uma forma material, seja na fala ou na escrita, seja por meio de imagens, objetos guardados, ruínas, monumentos... E quanto maior visibilidade e aceitação (ou imposição) social essas lembranças têm, mais elas integram a memória "oficial" de uma sociedade (SOETHE, 2009, p.161).

Desse modo, a literatura faz uso do discurso como mecanismo consciente de fixação da memória. "E como interessa aos textos literários figurar as dinâmicas do discurso, as obras procuram abrigar a pluralidade de vozes, incluindo os diversos pontos de vista que contribuem para fixar os conteúdos da memória" (SOETHE, 2009, p.161). Ou seja, quando o texto trabalha, como, por exemplo, com a imagem de uma pessoa ou fato histórico, suas personagens apresentam cada qual seu ponto de vista sobre o assunto, como forma de reforçar a presença e o impacto causado pelo objeto histórico na sociedade. Assim, não apenas o discurso literário, mas o discurso histórico passa a refletir sobre a existência da pluralidade de vozes sobre algo histórico, como vemos: 
O pensador Walter Benjamim (1892-1940) foi um dos principais responsáveis pela maior consciência em relação a essa pluralidade de perspectivas, que sobrevivem mesmo diante da fixação de uma "história oficial". Deve-se a ele, em grande medida, a consciência contemporânea sobre haver sempre modos diferentes de contar a história oficial, sob a perspectiva dos vencidos ou dos que não foram os atores principais no desenrolar dos acontecimentos (SOETHE, 2009, p.161).

A pluralidade de perspectivas tornou-se objeto de atenção de estudiosos, elevando "a importância de prestar atenção à diversidade de versões, perspectivas, pontos de vista diferentes na figuração de acontecimentos históricos pela arte, e em especial pela literatura" (SOETHE, 2009, p.162). Assim, os estudos comparativos possuem um grande interesse pelas análises literárias de narrativas que tentam elucidar dados históricos em sua composição, como Paulo Astor Soethe enfatiza:

Sob a óptica da literatura comparada, que busca diferenças, semelhanças e interfaces, já podemos imaginar o interesse dessa área de estudos pela relação entre literatura e história (como disciplina acadêmica) e também entre obras que, direta ou indiretamente, abordam um mesmo episódio ou contexto histórico, sob perspectivas diversas (SOETHE, 2009, p.162).

Desse modo, por meio da literatura comparada é possível aproximar obras de diferentes escritores e tempos, que abordem o mesmo dado histórico, apresentando as diferentes perspectivas sobre determinado fato. Mas, também ao mesmo tempo, é possível realizar um panorama das relações e interesses sociais de determinados grupos em determinada época na qual se contextualiza a narrativa.

Assim, ressaltamos que por meio de texto narrativos podem estar presentes depoimentos de pessoas envolvidas nos acontecimentos, ou dados com embasamento teórico que reforçam o comportamento e pensamentos das pessoas de um determinado período social, que de alguma forma possam explicar ou apontar um caminho para construções ideológicas dos dias atuais, como a construção do papel social do sujeito feminino negro que será evidenciado nesta pesquisa. 


\section{ASPECTOS CONSTRUCIONAIS DA PERSONAGEM FICCIONAL}

A narrativa ficcional é composta de elementos essenciais para a sua estruturação, entre eles está a personagem ficcional, um ser complexo que, quando bem construído, nos faz questionar seu surgimento. Como poderia um ser como Capitu, criado por Machado de Assis, nascer apenas do imaginário de alguém? São questionamentos assim que nos fazem perguntar de onde vêm esses seres capazes de nos despertar sentimentos, e, em muitas vezes, nos colocar em contato com suas alegrias e dores? Como leitores podemos até nos questionar se já foram seres do nosso mundo real, porém, mesmo quando baseados em alguém real, como o caso dos romances aqui analisados, ao serem ficcionalizados, sua existência está atrelada à narrativa e, sem ela, eles não existem, pois são seres construídos pela linguagem.

Como um bruxo que vai dosando poções que se misturam num mágico caldeirão, o escritor recorre aos artifícios oferecidos por um código a fim de engendrar suas criaturas. Quer elas sejam tiradas de sua vivência real ou imaginária, dos sonhos, dos pesadelos ou das mesquinharias do cotidiano, a materialidade desses seres só pode ser atingida através de um jogo de linguagem que torne tangível a sua presença e sensíveis os seus movimentos (BRAIT, 1985, p. 53).

Dessa maneira, independente de como surgem as personagens ficcionais, elas serão sempre seres imaginários construídos por meio de objetivos específicos de seus criadores e manipulados pela linguagem. Assim, por meio delas se desenvolve a narrativa, e só por meio dela que conseguimos analisá-las e entendermos seu processo de criação. Como Beth Brait ressalta:

Se o texto é o produto final dessa espécie de bruxaria, ele é o único dado concreto capaz de fornecer os elementos utilizados pelo escritor para dar consistência à sua criação e estimular as reações do leitor. Nesse sentido, é possível detectar numa narrativa as formas encontradas pelo escritor para dar forma, para caracterizar as personagens, sejam elas encaradas como pura construção linguístico-literária ou espelho do ser humano (BRAIT, 1985, p. 53).

O conhecimento que temos sobre as personagens, suas características, sentimentos e pensamentos são apenas aqueles que a narrativa nos proporciona, porém, algumas personagens são tão detalhadas que nos fazem como leitores vêlas como seres "palpáveis", ou seja, são seres como nós. Parte disso deve-se a 
outro elemento fundamental nesse processo de conhecimento do leitor com essas criaturas, o narrador, pois é ele que torna possível esse conhecimento ao leitor.

\begin{abstract}
Qualquer tentativa de sintetizar as maneiras possíveis de caracterização de personagens esbarra necessariamente na questão do narrador, esta instância narrativa que vai conduzindo o leitor por um mundo que parece estar se criando à sua frente. Ainda que este capítulo não tenha por objetivo discutir o papel do narrador, não há como fugir desse elemento presente, sob diversas formas, em todos os textos caracterizados como narrativas. Como podemos receber uma história sem a presença de um narrador? Como podemos visualizar uma personagem, saber quem ela é, como se materializa, sem um foco narrativo que ilumine sua existência? Assim como não há cinema sem câmera, não há narrativa sem narrador (BRAIT, 1985, p.53-54).
\end{abstract}

Dessa maneira, os dados sobre a personagem são transmitidos pelo narrador, como uma espécie de câmera que repassa aos nossos "olhos" tudo o que se passa dentro da narrativa. Ademais, a personagem é de suma importância para a narrativa, pois como Antonio Candido explana: "o enredo existe através das personagens; as personagens vivem o mundo do enredo. Enredo e personagem exprimem ligados, os intuitos do romance, a visão da vida que decorre dele, os significados e valores que o animam" (CANDIDO, 2017, p. 39).

É por meio da personagem que ocorre o sentido de movimento da narrativa, criando seu efeito de verossimilhança. Assim, para obter sucesso nesse recurso, a primeira tentativa do escritor ao construir sua personagem é criar credibilidade de sua existência no leitor, "por meio de uma descrição mais empírica possível a nossa percepção de semelhante" (CANDIDO, 2017, p. 39).

Antonio Candido faz a distinção entre pessoa e personagem pela forma como podemos interpretá-las, pois da pessoa temos um conhecimento fragmentado, já que não podemos saber exatamente o que pensa e sente. Já no romance, "o escritor estabelece algo mais coeso, menos variável, que é a lógica do personagem" (CANDIDO, 2017, p. 43). Assim, o escritor pré-estabelece dados e os seleciona de forma a limitar-se em busca de uma lógica, e todos os seus dados ficam à mostra para o leitor.

O processo de diferenciação entre pessoa e personagem levantado por Antonio Candido (2017) aplica-se normalmente em relação ás personagens construídos com base em pessoas reais, como no caso das personagens dos romances a serem analisados neste trabalho, pois independente do meio usado por 
seus criadores para sua existência, todas as personagens são constituídas pela linguagem. Ademais, outros aspectos podem ser comparados a fim de evidenciar a distinção entre elas, como vemos:

O Homo fictus é e não é equivalente ao Homo sapiens, pois vive segundo as mesmas linhas de ação e sensibilidade, mas numa proporção diferente e conforme avaliação também diferente. Come e dorme pouco, por exemplo; mas vive muito mais intensamente certas relações humanas, sobretudo as amorosas (CANDIDO, 2017, p. 63).

Essa afirmação do escritor nos faz observar que toda narrativa tem enfoque maior nas experiências e sentimentos. Assim, raramente na narrativa aparecem descrições de refeições e das personagens dormindo, e quando aparece, nunca serão na mesma proporção que os seres humanos fazem. Mas, esse aspecto não acarreta na perda de credibilidade da obra em contraste com o mundo real, pois como leitores não criamos expectativas com esses fatos, e sim com a possibilidade de conhecer alguém por sua totalidade, como conhecemos a personagem, pelo seu exterior e seu interior, algo que jamais teríamos ao conhecer uma pessoa real.

Nesse caso, as personagens ficcionais dos romances de Agripa Vasconcelos, João Felício dos Santos e Joyce Ribeiro são interpretações da histórica e lendária Francisca da Silva Oliveira, pois é impossível o escritor conseguir fazer uma cópia de uma pessoa histórica, já que, em se tratando de uma pessoa real, o conhecimento sobre ela seria fragmentado, não havendo possibilidade de criar uma imitação em relação a essa pessoa.

Por outras palavras, pode-se copiar no romance um ser vivo e, assim, aproveitar integralmente a sua realidade? Não, em sentido absoluto. Primeiro, porque é impossível, como vimos, captar a totalidade do modo de ser duma pessoa, ou sequer conhecê-la; segundo, porque neste caso se dispensaria a criação artística; terceiro, porque, mesmo se fosse possível, uma cópia dessas não permitiria aquele conhecimento específico, diferente e mais completo, que é a razão de ser, a justificativa e o encanto da ficção (CANDIDO, 2017, p. 65).

Assim, o que ocorre no romance histórico é a criação de personagens com o propósito de apresentar uma possível história que preencha as lacunas sobre a vida da pessoa escolhida como base para a construção de um trabalho, ou seja, o escritor apresenta possíveis sentimentos, pensamentos e ações que a pessoa histórica poderia ter experienciado. 
Por isso, quando toma um modelo na realidade, o autor sempre acrescenta a ele, no plano psicológico, a sua incógnita pessoal, graças à qual procura revelar a incógnita da pessoa copiada. Noutras palavras, o autor é obrigado a construir uma explicação que não corresponde ao mistério da pessoa viva, mas que é uma interpretação deste mistério; interpretação que elabora com a sua capacidade de clarividência e com a onisciência do criador, soberanamente exercida (CANDIDO, 2017, p. 65).

Dessa maneira, não é a imitação ao mundo real que ocasiona a veracidade da personagem, mas digamos que uma personagem nos parece real quando "o romancista sabe tudo a seu respeito" (CANDIDO, 2017, p. 65), ou produz esta impressão, mesmo que não o diga. É como se a personagem fosse inteiramente explicável; e isto the fornece uma originalidade maior que a da vida, cujo conhecimento é, como vimos, fragmentário e relativo. Assim, o conforto, a sensação que nos transmite o romance proporciona a experiência de "uma raça humana mais manejável, e a ilusão de perspicácia e poder" (CANDIDO, 2017, p. 68).

Desse modo, o escritor procura conquistar a credibilidade do leitor com sua história, mas é "incapaz de reproduzir a vida" e à medida que tenha como objetivo reproduzi-la, seu romance tende a ser um fracasso, pois o encanto está na criação de um novo mundo. Nos casos aqui analisados, se os escritores se propusessem a reproduzir a pessoa histórica de Francisca da Silva, suas personagens não causariam tanta empatia no leitor, pois o encanto da obra está na construção que se inspira na História para criar um novo mundo.

As personagens constituem um dos principais elementos da narrativa responsáveis pela construção da veracidade da obra, pois, como William H. Gass afirma, o objetivo por meio da personagem é "fixar na memória do leitor, como uma presença viva, uma viva imagem humana" (GASS, 1974, p. 42). Assim, Gass ressalta que as personagens são constituídas por algo único, fixo, não pertencente ao mundo real, onde as pessoas são seres instáveis.

Embora os manuais procurem nos ensinar como se criam os personagens, jamais nos dizem minuciosamente que estamos fazendo imagens, ilusões, imitações. Gatsby não é uma imitação, pois não há nada que ele imite. Na verdade, se fosse uma cópia, uma ilusão, uma espécie de sombra, não seria de modo algum um personagem. Tem de ser singular, inteiramente ele mesmo, como se tivesse um ego. Exige-se, de fato, do personagem que aja de acordo, como um gato no saco (GASS, 1974, p.44). 
Dessa maneira, a personagem torna-se um elemento maleável pelo escritor para fins específicos, assim algumas de suas ações já são esperadas diante dos acontecimentos, pois, diferente dos seres humanos, podemos conhecê-los em sua profundidade, principalmente as personagens do romance.

No que diz respeito especificamente ao romance e à personagem de ficção, é somente com a obra Teoria do romance, de Gyorgy Lukács, publicada em 1920, que essas questões são retomadas em novas bases, Lukács, relacionando o romance com a concepção de mundo burguês, encara essa forma narrativa como sendo o lugar de confronto entre o herói problemático e o mundo do conformismo e das convenções. O herói problemático, também denominado demoníaco, está ao mesmo tempo em comunhão e em oposição ao mundo, encarnando-se num gênero literário, o romance, situado entre a tragédia e a poesia lírica, de um lado, e a epopéia e o conto, de outro. Nesse sentido, a forma interior do romance não é senão o percurso desse ser que, a partir da submissão à realidade despida de significação, chega à clara consciência de si mesmo (BRAIT, 1985, p. 39).

Ademais, as personagens são os seres que conduzem as ações da narrativa, assim Salvatore D'onofrio afirma que personagem e enredo desempenham uma relação indissociável na obra, pois "as personagens constituem os suportes vivos da ação e os veículos das idéias que povoam uma narrativa" (D'ONOFRIO, 1983, p. 55). Dessa maneira, é por meio das personagens que acontece o enredo. Porém, apesar de as personagens possuírem a mesma função nas narrativas, alguns elementos os assemelham-se a eles, os elementos invariáveis, e os distinguem entre si, os elementos variáveis.

Os elementos "variáveis" são constituídos pelos nomes das personagens, sexo, idade, atributos, enfim, pelo conjunto de suas qualidades externas e suas caracterizações psicológicas. Como elementos "invariáveis" podem ser considerados os sujeitos das funções da narrativa, que Propp agrupa em "sete esferas de ações das personagens" (D'ONOFRIO, 1983, p. 55).

Desse modo, os estudos comparativos de personagens, baseados em um elemento histórico comum são de grande importância, pois é evidente a existência de discrepâncias entre si, considerando que cada escritor possui maneiras distintas de interpretações. Como no caso dos romances dos escritores Agripa Vasconcelos, João Felício dos Santos e Joyce Ribeiro, que são propostos para análise, os quais evidenciam interpretações da pessoa histórica de Francisca da Silva de Oliveira, conhecida popularmente como Chica da Silva. Dessa maneira, por meio dos 
romances, a figura de Chica apresenta novas vidas ou sobrevidas, advindas de suas diversas e distintas interpretações.

[...] mas também novas vidas ou sobrevida: essas sobrevidas prolongam a existência da personagem para além do romance em que primeiro habitou e dependem de uma fenomelogia da recepção e de atitudes cognitivas que fazem dela uma entidade dinâmica e suscetível de refiguração (REIS, 2015, p.130).

Essas sobrevidas de Chica da Silva são perceptíveis por meio da literatura, pois sua imagem foi muito trabalhada pelo ficcional, sob diversas perspectivas, ademais, mais tarde, sua imagem passa a ser trabalhada também pela cinematografia. Assim, as inúmeras interpretações feitas de sua história resultam em processo de refiguração e reafirmação de sua existência na sociedade brasileira do século XVIII. Dessa maneira, salienta-se a importância da análise e confronto da personagem protagonista Chica da Silva construída pelos escritores Agripa Vasconcelos (1966), João Felício dos Santos (1976) e Joyce Ribeiro (2016), pois nota-se uma distância temporal considerável entre a produção das obras que podem interferir no processo de construção da personagem, considerando que cada período possui pensamentos e ideologias distintos entre si.

\subsection{CHICA QUE MANDA, DE AGRIPA VASCONCELOS (1966)}

Agripa Vasconcelos escreve o romance Chica que manda, publicado pela primeira vez em 1966. Vasconcelos era mineiro, iniciou sua carreira literária com o livro Silêncio (1920), que o levou, aos 22 anos de idade, a conquistar um lugar na Academia Mineira de Letras, sucedendo a Alphonsus de Guimaraens. Em 1949, obteve o prêmio Olavo Bilac da Academia Brasileira de Letras. Ele atuou como médico e escritor, tendo evidente interesse por assuntos de natureza variada, todavia a literatura é que se torna o epicentro da propagação de suas ideias. Publicou alguns ensaios e textos de caráter cientifico na área da saúde, mas dedicou-se mesmo em produzir poesias, prosas e romances.

E não sem razão. Sua obra, múltipla e vasta, revela o domínio da narrativa, a paixão pela matéria viva e o real, a inteligência lírica que a fazem detentora de beleza universal. Através de cuidadosa pesquisa com as palavras, que vai buscar nos falares antigos, nos dialetos africanos, nas prosas mineiras, Agripa revela um tesouro 
escondido de sons, cores e emoções que ele nos convida a descobri (MANCINI; MENON; SILVA, 2018, p.11).

Ademais, Vasconcelos foi um grande adepto do gênero romance histórico, destacando-se pela publicação da Saga do País das Gerais, composto por sete romances que retratam Minas Gerais em momentos diferentes de seu desenvolvimento, do período colonial ao imperial. Com estilo próprio e hibrido, seus romances são um misto de história, romance histórico e bibliografia ficcional. Suas obras são resultantes de anos árduos de investigação, viagens e de coleta de informações acerca do território mineiro e seus protagonistas.

Nesse conjunto de obras, o escritor procurou ao ficcionalizar a história mineira, recuperar fatos e personagens que compõem ciclos importantes do estado. Assim, cada livro reflete um ciclo especifico, como vemos: Fome em Canaã romance do ciclo dos latifúndios nas Gerais; Sinhá Braba - $D$. Joaquina do Pompéu - romance do ciclo agropecuário nas Gerais; A Vida em Flor de Dona Beja romance do ciclo do povoamento nas Gerais; Gongo-Sôco - romance do ciclo do ouro nas Gerais; Chica que Manda - romance do ciclo dos diamantes nas Gerais; Chico Rei - romance do ciclo da escravidão nas Gerais, e Ouro Verde e Gado Negro - romance dos ciclos do café e da abolição do cativeiro nas Gerais.

Entre os romances da Saga, destaca-se a obra Chica que Manda, publicada em 1966, cuja narrativa baseia-se na figura de Francisca da Silva Oliveira. Nessa narrativa, o escritor faz uma mistura de dados historiográficos, romance histórico e biografia ficcional, com descrições detalhadas e acontecimentos importantes na história de Minas Gerais e do arraial do Tejuco, com o objetivo de propiciar ao leitor conhecimento sobre o lugar em que se passa a narrativa, e, ao mesmo tempo, preparando a apresentação da protagonista em seu período da história mineira.

No romance Chica que manda, Agripa Vasconcelos distrai o leitor com extensas exposições sobre a paisagem agreste e tradições locais e pinta o ciclo dos diamantes mediante uma linguagem farta de regionalismos. A história vem emoldurada por um número expressivo de personagens e historietas paralelas. Agripa Vasconcelos busca ressaltar a história do Estado de Minas Gerais e de seus principais habitantes. Urde uma história, consistente e plausível, com o Setecentos mineiro, pautando-se por uma pesquisa documental. Além de fontes, fatos e personagens do período, porém tece um enredo com informações históricas e com a imaginação, tornando, assim, indefinidos os limites entre a história e a ficção (CALEIRO, NASCIMENTO, 2011, p. 225). 
$\mathrm{Na}$ narrativa, a personagem Chica da Silva é uma modesta escrava do sargento-mor José da Silva e Rolim, que supostamente seria seu pai. Dessa maneira seria filha de mãe negra e pai branco. Ela é descrita como "morena, alta, enxuta de carnes e cabelos negros escorridos de filha de branco" (VASCONCELOS, 2010, p.61).

O grande desenlace da narrativa está no evento de ela encantar o contratador de diamantes e desembargador João Fernandes de Oliveira, de tal modo que ele a compra a fim de torná-la sua esposa. Quando ela transita de escrava para esposa, ou seja, torna-se senhora, recebe alforria e adapta-se à classe senhorial branca. Chica torna-se, depois de se juntar ao contratador João Fernandes uma mulher com instrução básica e elegante, possuidora de inúmeras joias e vestidos, tipicamente uma dama da sociedade.

$\mathrm{Na}$ obra, ela se apaixona também pelo contratador de diamantes João Fernandes de Oliveira, e, envolvida por um ciúme doentio dele, pratica atos de crueldade contra escravos e escravas, toda vez que se sente ameaçada em relação ao seu casamento com o contratador. Atos esses, que ao serem cometidos, proporcionam-Ihe prazer e contentamento.

Chica e João Fernandes viviam uma vida exuberante e glamorosa, pois eram o casal mais rico do arraial do Tejuco. Assim, chamavam cada vez mais a atenção das pessoas da sociedade sobre si, incomodando principalmente seus inimigos, que os invejavam e questionavam o posto social ocupado por Chica, de mulher mais poderosa do arraial, pois tinhas aos seus pés o contratador e muitas amizades de pessoas importantes da sociedade. Isso resultou em inúmeras denúncias à corte, principalmente no que diz respeito ao seu relacionamento amoroso com João Fernandes de Oliveira e ao seu estilo exuberante de vida. Assim, é enviado o Conde Valadares, que por muitos dias se aproveita da hospitalidade e bondade do contratador João Fernandes e, ao fim, o engana, levando-o para Portugual com a promessa de renovação do contratado dos diamantes, porém ele estava sendo intimado por supostas irregularidades em sua gestão.

A partida de João Fernandes abala Chica da Silva, pois ela sentia que algo ruim esperava por ele em Portugal. Ao chegar a Portugal, o contratador se depara com uma situação perturbadora: a corte lhe cobrava o valor de dez milhões por irregularidades no seu contrato, e mesmo ele pagando a multa, não foi liberado para 
voltar para o Brasil, pois representaria uma ameaça para a corte, devido a sua influência na colônia.

Dessa maneira, Chica passou o resto de seus dias sozinha, sem o amor de sua vida. E, depois de um de seus escravos fugir e denunciá-la por crimes sádicos que cometeu, apesar de ter sido considerada inocente, vivia pertubada, pois tinha medo de a verdade aparecer e sua imagem de "santa" ser destruída. Assim, desenvolveu problemas cardíacos e, logo após, passou a ver alucinações referentes aos atos que cometeu. Ao fim, veio a óbito, como o único desfecho possível para a protagonista, pois após a partida de João Fernandes, viveu seus dias à sua espera, e na morte, segundo o desfecho, seria a única forma de reencontrá-lo.

$\mathrm{Na}$ narrativa é notável que a protagonista Chica da Silva passa por um movimento de evolução, que tende a surpreender o leitor, pois no início é descrita como uma mulher comum, e conforme seu relacionamento com o contratador João Fernandes vai criando raízes, ela vai se transformando em uma nova mulher, porém ora ela é culta e bondosa, ora ela é cruel e sádica.

Forster (1949) apresenta uma distinção de personagens, entre os nomeados de "flat, ou, personagens planos", que seriam personagens tipificados, sem profundidade psicológica, e, "round, ou, personagens esféricos", que seriam personagens complexos e multidimensionais. Assim, por meio dessa distinção, percebemos que a personagem de Agripa Vasconcelos é classificada como uma personagem esférica.

As "personagens esféricas" não são claramente definidas por Forster, mas concluímos que as suas características se reduzem essencialmente ao fato de terem três, e não duas dimensões; de serem, portanto, organizadas com maior complexidade e, em conseqüência, capazes de nos surpreender. "A prova de uma personagem esférica é a sua capacidade de nos surpreender de maneira convincente. Se nunca surpreende, é plana. Se não convence, é plana com pretensão a esférica (CANDIDO, 2017, p. 47).

A evolução da protagonista é notável por meio das descrições feitas dela na narrativa. "João Fernandes recebeu o cálice mas deixou-se olhar a jovem que, de olhos baixos, aguardava. Era morena, alta, enxuta de carnes e cabelos negros corridos de filha de branco" (VASCONCELOS, 2010, p.65). Nesse momento, que se refere ao primeiro encontro entre os dois, vemos uma mulher escrava, submissa, com características atraentes, por julgar que João Fernandes tem seu olhar atraído 
a ela. Porém, com o desenrolar da narrativa, ela torna-se uma pessoa ativa socialmente, "Chica botava panos quentes em muitos casos, defendia, ajudava os perseguidos" (VASCONCELOS, 2010, p.121), assim, ela deixa de ser submissa, passando a ser uma mulher proativa, porém ninguém esperava que, por ciúme doentio, essa mesma mulher pudesse ser tão cruel, a ponto de castigar todas as pessoas que de alguma forma representassem alguma ameaça ao seu relacionamento. Desse modo, notamos que ocorrem mudanças comportamentais na protagonista, que de escrava submissa, torna-se uma figura emblemática, um misto de bondade e de crueldade.

A narrativa tem como enfoque a vida de Chica da Silva e a vivência das pessoas no arraial do Tejuco, assim percebe-se que ao longo do enredo existem situações que são comentadas por diversos personagens diferentes, exemplo disso é quando João Fernandes compra Chica para ser sua esposa. "Ora, pois tudo mundo sabe quem é Chiquinha, queimada, por ser trigueira. A que teve filho do Dr. Sardinha" (VASCONCELOS, 2010, p.68).

Inclusive, destaca se que o escritor Agripa Vasconcelos chamou o romance de Chica-que-manda justamente pelo fato de ela ser chamada de Chica queimada a analogia fonética que o autor faz, remete primeiro ao fato de ela passar a ser a senhora, mas também esconde essa questão de como a chamavam pela cor da pele. Ademais, nesse trecho, a personagem é rebaixada socialmente duas vezes, a primeira pela palavra "trigueira". Segundo Caleiro e Nascimento (2011) o termo refere-se "que marca pele escura, parecida com a cor do trigo maduro que a atrela à feiúra e á sujidade", aqui percebe-se um julgamento a sua tonalidade de pele, e, no final do trecho, ela é criticada por já ter engravidado, pois ambas as colocações a desclassificavam nesse período para o casamento, esse era para mulheres brancas e virgens, como reforçado em outro trecho:

-Está ai. Ela é mulher parida, já vinha muitas vezes vasculhada por homem português devasso. Agora cai no gôto de outro como engraçada. Há muitos mistérios na questão do sexo. Homens belos amam a mulheres feias [...] Existe qualquer mistério nessas preferências (VASCONCELOS, 2010, p.71).

A escolha de João Fernandes é questionada por toda a sociedade, pois a escolha de uma mulher negra escravizada para o posto de esposa de um dos homens mais poderosos naquela época era inaceitável para os valores do século 
XVIII. Porém, o nome desse capítulo "Diamante negro", que é o terceiro da narrativa, sugere que Chica da Silva seria uma mulher bonita, assim Agripa Vasconcelos inicia com uma citação de Sóter Couto que estudou a região, hoje conhecida por Diamantina, expressando o seguinte argumento:

...achamos que Chica da Silva foi uma mulher mulata bonita, tal a forte paixão que despertou, primeiro no Dr. Manoel Pires Sardinha e depois no Desembargador João Fernandes, que se deixou enlear nas redes de um forte amor, satisfazendo a todos os caprichos da escrava que passou a ser a Rainha do Tijuco (COUTO, 1954, p. 53).

Assim, observamos que provavelmente Chica da Silva foi uma mulher bonita para os padrões de beleza do século XVIII, e essa citação é utilizada pelo escritor Agripa Vasconcelos como base teórica para a construção da personagem e justificativa para o envolvimento dela com João Fernandes, mesmo havendo tantas restrições socais que a tornavam inapta para esse relacionamento. Na narrativa, também é possível notar a preocupação de João Fernandes em "lapidá-la", como se fosse um "diamante bruto", pois no momento em que a tornou sua esposa, sua primeira preocupação está em vesti-la como uma verdadeira dama.

Foram chamadas à casa do contratador as costureiras mais hábeis do arraial, irmãs do major Guerra, para vestirem Chica do que houvesse de melhor e mais caro no comércio tijuquense.

- Não façam economias. Quero tudo com muito luxo e sob medida.

Martinha era a bordadeira e rendeira maravilhosa do Tijuco.

- Você passa a trabalhar só para Francisca. O que aqui não se encontrar, mando vir de Vila Rica.

As três artistas passaram a trabalhar com exclusividade para florir a tetéia do desembargador (VASCONCELOS, 2010, p.69-70).

O trecho acima enfatiza que o contratador João Fernandes não mediu esforços e dinheiro na tarefa de tornar Chica uma mulher da elite. Assim, começamos a conhecer Chica da Silva como a rainha do Tejuco "-Ontem escrava, hoje rainha. Entenda-se o mundo. Nasceu de africana repelente na enxerga de uma senzala, filha espúria, agora habita um palácio, tem escravas, manda e não pede..." (VASCONCELOS, 2010, p. 70).

Muitas pessoas ficavam indignadas pela posição social de Chica da Silva, pois não a aceitavam pela sua origem de escrava, porém ela não se importando com comentários maldosos, bem vestida, passa a adquirir hábitos e frequentar lugares 
tradicionais da elite local, como as missas dominicais na igreja, lugar onde faz sua primeira aparição pública como esposa do contratador João Fernandes de Oliveira.

Chegara à hora da missa do dia, no domingo de céu lavado pela chuva da noite. Mas os que estavam na porta da igreja tiveram uma surpresa: Chica chegou ao tempo numa cadeirinha de arruar, conduzida por dois escravos de libré. Acompanhavam a cadeirinha azul e ouro seis escravas vestidas de seda cor-de-rosa, bem calçadas e de boinas brancas na cabeça. Chica entrou na igreja com a missa começada e foi-se ajoelhar ostensiva logo atrás das grades das comunhões. Muitas devotas se espantaram. Dona Laurita cutucou com o cotovelo a irmã Adélia:

-Minha irmã, que estou vendo?

-Está vendo riqueza. É: a que foi escrava e já está pisando em nós, de família nobre dos paulistas.

Na porta alguns sorriram. Mota foi um deles:

-Não falo? Ficou até bonita...

Guerra falou, como justificando:

-É a mocidade. Quem é moça é também bela.

-O que é lindo é seu vestido verde. Seda muito fina, os borzeguins de pelica... E este cheiro gostoso que ficou atrás dela. Já foi alforriada por documento público. [...] (VASCONCELOS, 2010, p.73).

As descrições de Chica vão evidenciando algumas mudanças que ocorrem com ela quando se torna senhora da "Casa grande". Dessa maneira, além das vestimentas e estilo de vida luxuosos, ela começa a desenvolver outros hábitos pertencentes à elite branca por meio de suas amigas lisboetas, que eram responsáveis por "Ihe polir as maneiras, fazendo-a elegante e conservadora razoável" (VASCONCELOS, 2010, p.90), assim, Chica foi educada conforme os moldes da sociedade européia, promovendo saraus de música, bailes e peças de teatro, constituindo-se uma típica mulher burguesa, bem-educada, refinada e proativa no meio social.

Outra característica que Chica começa a apresentar é sua severa autoridade sobre seus escravos e escravas.

Agora, tudo mudado. Era senhora de suas vontades, via-se endeusada por milionário que exigia tivese ela o trato de mulher rica. Mas faltava muita coisa a ser polida no caráter da trigueira. Com a súbita mudança de mucama para senhora, ganhou atitudes um tanto insolentes e tratava com severidade exagerada a seus serviçais (VASCONCELOS, 2010, p.77).

Assim, notamos que o narrador começa a preparar o leitor para conhecer o outro lado da protagonista, pois nesse trecho vemos que mesmo Chica já havendo 
sido escrava, isso não a impediu de tornar-se uma proprietária perversa com os seus, ou seja, aqueles que pertencem a sua origem, pois acaba desenvolvendo o que Gilberto Freyre (2006) chama de o "sadismo do branco". No desenvolvimento da narrativa, é possível notar como essa característica é construída e reafirmada durante toda ela, pois são os ciúmes de Chica somados a sua tendência sádica que serão trabalhados pelo escritor para enfatizar o seu lado rancoroso e cruel.

A primeira vítima dela será uma jovem chamada Gracinha, a qual ela conhece em um passeio com suas amigas lisboetas nas obras que João Fernandes realizava no Poção da Moreira, no Jequitinhonha. Chica percebe a beleza e desenvoltura da moça, e logo se preocupa se ela conhecia o seu esposo, pois ela nota que a jovem era a única a estar bem vestida entre as mulheres do lugar, "A senhora não acha esquisito aquela sujeita com vestido novo de chita, quando todas as mulheres daqui usam saias velhas e camisa de cabeção sem blusa?" (VASCONCELOS, 2010, p.107).

Chica soma a isso o fato de João Fernandes passar dias no local sem voltar para casa, alimentando sua imaginação de um possível caso entre eles. O que se fortalece dias após, quando Zezinho, irmão de Gracinha, aparece em sua casa para entregar um recado a João Fernandes. Logo, Chica supõe-se que seja um recado de Gracinha, assim, convocou seus escravos de confiança, entre os quais estava Jaconias que era "frio, sádico, insensato, sua alma parecia cheia de espinhos venenosos" (VASCONCELOS, 2010, p.107) e, comete seu primeiro ato de sadismo, ordenando seus escravos que o torturassem para que não trouxesse mais recados de sua jovem irmã ao seu esposo. No momento do ato, os escravos amarram Zezinho e mergulharam seus pés em um poço cheio de piranhas, que atacaram o jovem e, em poucos segundos, "os pés de Zezinho estavam reduzidos a ossos, com alguns dedos arrancados" (VASCONCELOS, 2010, p.117)

Paradoxalmente, quando ocorre o primeiro ato sádico de Chica sua fama de bondosa e caridosa com os desfavorecidos já estava disseminada pelo arraial, “Dona Francisca, a senhora é mãe desse povo" (VASCONCELOS, 2010, p.117), e o narrador ainda reforça:

Quando João Fernandes tomou conta de seus negócios no Tijuco, havia imensa opressão sobre escravos, forros e mulatos, coisa que continuou. Mas apareceu para amparar os choques um Anjo Negro.

Era Chica da Silva. João Fernandes nunca foi tão popular, nem 
humano com os cativos. Homem da lei, cumpri-a. Chica botava panos quentes em muitos casos, defendia, ajudava os perseguidos. Sabendo de ciência própria o que era escravidão e quanto pesavam os ferros impostos por direito e por injustiça, vendo-se poderosa, começou a ajudar os sofredores esmagados pelos portugueses (VASCONCELOS, 2010, p.121).

Assim, os pais de Zezinho sem ter para quem recorrer pedem a ajuda de Chica para socorrer seu filho. Nesse momento é que ocorre a primeira complexidade da personagem, pois ela havia ordenado a tortura contra o rapaz, mas ao ser solicitada a sua ajuda para salvá-lo, ela não mediu esforços: "Não. Você é o feitor de João Fernandes e seu filho terá todo o recurso que precisar! Não deixo faltar nada! Isto aqui não é como pensam, não! Temos recurso médico e seu filho será tratado como qualquer rico!" (VASCONCELOS, 2010, p.117). Assim, ela mandou chamar o doutor Malafaia para cuidar do doente e alugou um rancho para sua hospedagem, porem o jovem acabou falecendo.

Isso é um fato que realça a multiface da protagonista, pois o ato dela faz com que jamais a família de Zezinho desconfiasse de seu envolvimento no crime. Após a morte do rapaz, ela traz Gracinha para sua casa, como mucama, com a finalidade de vigiá-la, porém no decorrer da narrativa, novamente acometida por ciúmes, manda matar a moça.

Aqui percebemos que a personagem Chica, de Agripa Vasconcelos, é caracterizada como sádica pelo viés de cometer atos de crueldade por motivações fúteis, mas que a satisfazem de acordo com o seu humor. Uma das passagens da narrativa que expressa fortemente seu lado sádico é relativa à morte de Graça. Encomendada por Chica e motivada por ciúmes pelo contratador, a morte da jovem foi cercada de crueldade e tragicidade, uma vez que se mandou que a enterrassem viva, deixando apenas a cabeça descoberta. Após algumas horas do ato cometido "Às dez da noite, Chica mandou ver como iam as coisas. Sentia um desafogo confortador, um bem-estar, uma paz de água represada que serena depois do estrondo da cachoeira" (VASCONCELOS, 2010, p.209). Percebemos pelo descrito, a protagonista estava se sentindo satisfeita como a morte da escrava e com as circunstâncias que a envolveram. No dia seguinte, ela vai conferir a encomenda:

Chica foi ver a enterrada viva. As pálpebras violáceas estavam meio caídas e a boca entreaberta em espasmo final, deixando ver alguns dentes muito brancos. Os cabelos que outrora viviam floridos de sempre vivas estavam acamados no chão, sujos de terra. 
Em torno, as árvores molhadas gotejavam restos de água caída até a alva do dia. Nos lábios e nas pálpebras do cadáver formigas roíam a pele empalidecida.

Cabeça fora com ela. Recebeu ordens:

-Diga a Jaconias que traga um enxadão.

Arrancou uma folha e começou a mordê-la, calada. Ficou escutando. Não havia pássaros na manhã úmida. As árvores molhadas continuavam a gotejar no chão lamacento.

-Jaconias, arranque essa cabeça com o enxadão.

Com quatro golpes curtos e duros, como quem desenterra um toco, o preto arrancou a cabeça.

-Agora cave ai mesmo um buraco e enterre isso.

(VASCONCELOS, 2010, p. 209).

Observando o trecho transcrito, notamos como a morte encomendada possuía traços de pura crueldade, pois a ladina ${ }^{6}$ fora torturada, ao ter seu corpo enterrado, enquanto estava viva, e ali ter que esperar sua morte que era certa. Ao se deparar com a cena, Chica não se mostra abalada e nem arrependida, ainda inflige castigo ao corpo desfalecido, mandando-lhe arrancar a cabeça. Ato a que ela fez questão de assistir.

Seu sadismo é reforçado quando João Fernandes de Oliveira compra uma bela ladina, Anselma, e elogia a beleza de seus dentes. Chica, enciumada, manda arrancar todos, posteriormente manda a ladina apresentar-se com uma salva ${ }^{7}$ para o homem, "estavam na salva todos os dentes da própria Anselma, arrancados a torquês." (VASCONCELOS, 2010, p.148). Após o ato, "Havia paz na sua fisionomia descansada, apenas com as olheiras mais profundas. Leonor, que não vira Chica desde a antevéspera, não reconhecia ali a fera que mandou arrancar os dentes da mucama"(VASCONCELOS, 2010, p.150). Notamos que sua própria amiga não a reconhecia diante do acontecimento tão brutal que presenciava e que a causava conforto.

Esse trecho deixa explícita a complexidade de caráter de Chica da Silva, pois possuía duas versões de si completamente opostas estabelecendo a completude de seu ser, como ressaltado por Regina Caleiro e Vinícius Nascimento "Chica da Silva é uma personagem contraditória, capaz de extraordinárias manifestações de amabilidade e de um ódio inquebrantável a seus desafetos" (CALEIRO, NASCIMENTO, 2011, p. 239).

\footnotetext{
${ }^{6}$ Tratava-se de expressão para diferenciar os escravos já aculturados dos que ainda não o eram (chamados 'boçais').

7 Um tipo de bandeja de prata.
} 
Chica não suportava imaginar João Fernandes com outra mulher, prova disso é quando "Soubera que João Fernandes, procurado por fiscal do serviço no poção do Moreira, fora visto dormindo na rede da sala do velho forro Libório" (VASCONCELOS, 2010, p.153). Isso, incomodou Chica, pois o homem tinha duas filhas "Luzia, entrevada, e Catarina, rapariga de dezoito anos, muito atraente" (Idem, p. 153). Então, facilmente a protagonista se convence que essa seria amante de João Fernandes, assim, tenta persuadir os pais da jovem a entregarem-na para ser sua mucama, mas esse seu plano fracassa, já que os pais precisavam dela para cuidar de sua filha entrevada. Dessa maneira, seu lado sádico entra em ação, ordenando de forma precisa o seu próximo ataque no dia seguinte.

Quando a moça abriu o tapume, dois negros a agarraram, tapando-
Ihe a boca, para que não gritasse. A poucos passos da casa estava a
pequena praia do Jequitinhonha, junto aos poções. Amarraram as
mãos de Catarina para trás e os pés, bem juntos. Ataram-lhe na boca
um pano grosso, amarrado na nuca, pano que atravessava a boca
aberta à força. Levaram-na para bem junto da água, com parte do
corpo na raseira.
Os negros afastaram-se para umas pedras, atrás das quais
permaneceram em silêncio. Meia hora depois a água mareteou no
poço e flutuava a flor da água um vulto. Foi nadando vagaroso para a
praia; via-se agora bem, como um coqueiro semi-flutuante
(VASCONCELOS, 2010, p.155).

Dessa maneira, como já conhecido por Chica da Silva, naquele rio encontravam-se cobras enormes, e como esperado pela ação, a jovem é feita de presa por uma: "a sucuri constringia-Ihe o corpo, esmagava os ossos, apertando pernas, braços e tronco" (VASCONCELOS, 2010, p.155), e em questão de segundos, "espichou-se depois, começando a engoli-la pelos pés" (Idem, p.155). Na manhã seguinte, Chica ainda exigiu dos escravos um relatório preciso do ato, "Contaram tudo, porque viram. Ela apenas sorriu, montando seu malacara que partiu a meio galope" (Idem, p.156). Desse modo, percebemos que a mesma mulher bondosa, sentia-se contente com os atos cruentos que ordenava como meio de vingança pelo seu ciúme doentio, assim, realçando seu lado violento e sádico na narrativa.

O ciúme e crueldade de Chica são notados em outra cena, em que ela conhece Mariana, uma "jovem morena simpática, ninando uma criança branca recém-nascida" (VASCONCELOS, 2010, p.159), não conseguindo compreendera situação de dois mulatos conceberem uma criança branca, ela fica frustrada, e 
supõe que a criança não seria filho de seu escravo, assim, supõe que o bebê seria de João Fernandes de Oliveira. Sendo assombrada pela ideia, ela faz uma visita à casa do recém-nascido:

Pegou-o com jeito e saiu calma à beira do rio, com ele nos braços.
Quando a mãe viu, não teve susto. Sorria agradecida da lembrança
da patroa de pegar seu filho.
Chegando na barranca da pedra do poção fundo, ela desenrolou as
baetas do corpo do pequerrucho e, num gesto repentino, em assomo
alucinado, jogou a criança que despira no fundo do poço azul.
Mariana gritou, entrando na água para salvar o filho
(VASCONCELOS, 2010, p.175).

A atitude de Chica da Silva de cometer infanticídio, para Freyre são traços sádicos tidos como normais na esfera escravocrata do século XVIII, como ressalta "Aquele mórbido deleite em ser mau com os inferiores e com os animais é bem nosso: é de todo o menino brasileiro atingido pela influência do sistema escravocrata" (2006, p.354). Assim, o que ocorre com a protagonista é, primordialmente, uma influência desse sistema, pois ela passa a apresentar traços de sadismo quando deixa de ser escrava e torna-se senhora na sociedade; ao ocupar esse papel, necessariamente começa a agir como os senhores brancos. $\mathrm{Na}$ época em questão, atitudes como a de Chica eram vistas com certo grau de normalidade, pois considerando os escravos seres inferiores, a classe mais elevada fazia o que bem queria com eles.

Não se pode, todavia, apenas entender a configuração sádica que Agripa Vasconcelos impinge a ela por esse único viés. Percebe-se, a partir das citações feitas que existe, no que diz respeito ao sadismo, algo que excede o estofo cultural e social a que Chica fora elevada: primeiramente, alavancada sempre pelos ciúmes em relação a João Fernandes, a protagonista age sob um entorpecimento que lhe cega a razão, como que conduzida por força maior que a toma; em seguida, é descrito o prazer, a paz que seus atos cruéis Ihe causam. Entra-se, dessa forma, no complexo campo relativo aos desvios psiquiátricos, daqueles do mesmo naipe que acometem Medeia, da tragédia de Eurípedes, os quais a levam a atitudes extremas motivadas pela traição do marido.

$\mathrm{Na}$ narrativa a insensibilidade da protagonista é realçada com as descrições feitas sobre o seu relacionamento com as filhas, pois quando João Fernandes vai para Portugal, elas vivem pela primeira vez juntas, já que antes disso, "suas filhas 
viviam sob os olhos da avó" (VASCONCELOS, 2010, p.195), e depois para fins de estudo passam a residir as meninas no convento e os meninos no seminário. Assim, "amando as filhas, seus carinhos pareciam forçados. Estavam convivendo no mesmo palácio, bastante estranhas dentro da família". (VASCONCELOS, 2010, p.334) Já os meninos viviam para o estudo em ambientes distantes da mãe, e mesmo Simão que já era formado "parecia esquecido da mãe" (Idem, p.334). Dessa maneira, fica evidente que "os filhos da tejucana pareciam muito longe dos seus afetos, porque ela, Chica, em espírito e carne, com seu amor alucinante, era toda do desterrado João" (Idem, p.334).

Dessa maneira, o último ato de crueldade de Chica da Silva estabelece sua imprevisibilidade e indiferença materna, pois quando se torna amiga da lisboeta Dona Leonor, ela encanta-se por sua filha Manoela, que era culta, branca, educada e talentosa. Assim, ela desenvolve um carinho maternal pela moça, "Manoela morava com Chica, sua grande amiga e companheira nas cavalgadas matinais pelos arredores" (VASCONCELOS, 2010, p.137). Chica se afeiçoou muito pela moça, de forma que ela era "o dodói de Chica" que a vestia com os melhores vestidos e cuidava da moça como se fosse sua filha.

Porém, quando planejam contra Manoela, a incriminando de uma suposta traição com João Fernandes, esta conhece a fúria de Chica da Silva, pois como enfatizado na narrativa "ninguém traía Chica sem provar no corpo as garras de sua vingança, garras que acabavam sempre gotejando sangue" (VASCONCELOS, 2010, p. 268). Como Manoela era uma mulher da elite branca, ela resolveu vingar-se por meio de sua honra, esperando um momento público e oportuno para agir. Assim, ofereceu um chá em sua casa, estavam ela e as senhoras convidadas reunidas no salão de visitas, quando avistou Manoela e sua mãe chegando:

- Que vem fazer aqui, mulher cínica? Vem buscar seu amante João Fernandes, para sua pouca-vergonha de mulher depravada? Você me enganou por muito tempo, mas agora escute minha ordem: Saia daqui, cachorra! Estou te tocando! Nunca mais pise na minha casa, sua puta!

D. Leonor, chocadíssima balbuciou:

-Que é isto, Dona Francisca?

Chica não respondeu. Ofegava, pálida, trêmula, desvairada.

Manoela tapou os olhos com as mãos, soluçando alto. De pé, na entrada do salão, parecia paralitica, petrificada.

D. Leonor abraçou-a, saindo com ela ainda sacudida por um violento soluço [...] (VASCONCELOS, 2010, p. 284). 
Chica, desse modo, difamou a honra da pobre moça, que não havia cometido traição alguma, e que agora carregava em seu nome a mancha da desonra que, para uma mulher do século XVIII, a prejudicava na única maneira que possuía para ascensão, o casamento. Assim, obrigou-se a casar com "um bargante da ralé, ébrio habitual e jogador. Já com um filho" (VASCONCELOS, 2010, p.360) como forma de evitar o peso da desonra, porém na primeira briga com o marido "perdera dois dentes da frente" (Idem, p.360), assim, a jovem perdeu "aqueles dentes claros que floriam seu sorriso simpático" (Idem, p.360) e, Chica estava vingada.

O desfecho de Chica é trágico, como ocorre com diversas protagonistas que são desviantes dos bons costumes da época. Exemplo disso, é Emma Bovary, de Gustave Flaubert, que ao cometer a ação desviante do adultério, acaba suicidandose por seus atos. Assim, percebemos que Chica da Silva, ao ter suas ações sádicas reveladas, possui um frasco de veneno guardado e pensa em suicídio, porém não havendo provas de seus atos, o caso é encerrado e ela inocentada. Mas, seu medo de ser descoberta a leva a problemas cardíacos e a ver alucinações:

De repente, gritou. Jelena acudiu. Ela já sentara no leito e sua camisa de Bretanha estava levantada até o meio das coxas.

-Uma cobra negra, enorme, se enrolou no meu corpo, quebrando os ossos. Ela está no quarto! Alguém tentou me amarrar as pernas e os braços. Veja onde está a cobra! (VASCONCELOS, 2010, p. 383).

Ademais, continuou vendo e escutando outras coisas estranhas:

- Vou confessar de novo. Vejo uns vultos passando perto de mim. Vultos brancos... Sombras gemendo, gritando. Escute. Estão de novo gemendo. Agora é choro de menino. Que menino está ai, atrás da porta?

Jelena chorava, esgotada pela trabalhosa vigia.

- Você acredita em fantasmas? Eu também não. O que vejo agora são sombras silenciosas deslizando sobre o chão... vultos que passam, voltam... Olhem aí um; este não desliza, não anda; sentado, se arrasta pelo assoalho (VASCONCELOS, 2010, p.184).

Os trechos acima são a comprovação de que a personagem estava atormentada pelos seus atos cruentos, pois é possível identificar três crimes cometidos por ela em suas alucinações. O primeiro relaciona-se a jovem Catarina que foi engolida por uma enorme cobra. E, no segundo momento, o "choro de menino" relaciona-se ao bebê de Mariana, que Chica jogou no poço, e a sombra que desliza pelo chão está referindo-se a Zezinho, que teve seus pés comidos por 
piranhas. Isso nos direciona à decadência da grande mulher da elite tejucana que foi Chica da Silva que, por fim, acaba atormentada por seus próprios atos, pioram seus problemas de saúde levando-a à morte, depois de anos de solidão longe de João Fernandes. Essa seria sua punição por apresentar-se como uma mulher desviante para os padrões sociais e morais da sociedade de sua época.

$\mathrm{Na}$ narrativa Chica que manda, de Agripa Vasconcelos, percebemos que o sujeito é a protagonista Chica da Silva e o objeto seria o seu esposo João Fernandes de Oliveira, pois o processo de transformação de Chica ocorre devido ao seus ciúmes e medo de perder João Fernandes, seu objeto de querer. Assim, elimina todos os que representem uma ameaça ao seu relacionamento com ele. Ademais, na narrativa também é instaurada a relação ajudante vs oponente, pois "o sujeito, na sua caminhada rumo à posse do objeto-valor, geralmente precisa do auxílio de outros actantes" (D'ONOFRIO, 1983, p. 56). Por esse viés, Chica possui seus escravos de confiança que colocam em prática todos os seus planos sádicos contra seus oponentes, assim, o contato direto dos atos de Chica, na maioria das vezes, ocorre entre os escravos com as vítimas, e não com ela.

Dessa maneira, por meio da análise de estrutura actancial postulada por Salvatore D'onofrio (1983), percebemos que a principal relação sintática do discurso, ocorre entre sujeito vs objeto, como enfatizado:

A estrutura actancial repousa sobre a principal relação sintática do
discurso, que opõe sujeito vs objeto. Do ponto de vista semântico,
este eixo sintático indica o "querer", o desejo que leva à procura:
"sujeito" de uma ação é quem sente falta de algo e inicia um
processo de transformação para possuir o objeto desejado; "objeto é
a coisa desejada, o valor de que se sente falta (D'ONOFRIO, 1983,
p. 56).

Outro aspecto importante é a composição psicológica da personagem, pois conhecemos suas paixões, ódios, medos e desejos. Salvatore D'onofrio (1983, p.57) destaca que, "do ponto de vista psíquico, a vontade de possuir o objeto do desejo, em contraste com o medo do fracasso perante os virtuais obstáculos. Neste caso, evidentemente, trata-se de uma narrativa de fundo psicológico". Logo, percebemos que Chica possui medo de perder seu espaço na vida do contratador João Fernandes para outra mulher, o que a leva a cometer inúmeras atrocidades contra aqueles que ameacem o equilíbrio de sua relação. 
Com a protagonista da narrativa de Agripa Vasconcelos ocorre um sincretismo atorial, ou seja, "um único ator para exercer todas as funções actanciais" (D'ONOFRIO, 1983, p.57), pois a personagem faz o papel de sujeito e ao mesmo tempo de destinador, que é estabelecido pela relação sintática entre destinadorobjeto-destinátário, a qual é expressa nessa narrativa na construção de Chica como planejadora e mandante nos crimes a serem praticados nos destinatários. Dessa maneira, a personagem que apenas no início da narrativa tinha o "querer" da situação consegue o saber e poder para alcançar o que tanto almeja.

O estudioso Salvatore D'onofrio por meio das funções actanciais enfatiza que todo actante possui uma missão a executar, ou seja, um "papel temático", assim, ele oferece como meio para esse tópico analítico uma classificação de personagens entre planos e esféricos, que lembra a de Foster. Por meio dessa classificação, observamos que a protagonista Chica se enquadra como esférica pelos seguintes requisitos:

No segundo caso, a narrativa apresenta a personagem inicialmente como um assemantema ou zero semântico, sem nenhuma qualificação: é a personagem "de natureza" ou "esférica", que será modelada aos poucos, holofrasticamente. Exemplo: o tipo de herói problemático do romance contemporâneo, indeciso e complexo, inadaptado ao meio ambiente, que não sabe o que quer e nem para onde ir (D'ONOFRIO, 1983, p. 58).

Assim, como já exposto, a protagonista é uma mulher complexa, pois apresenta duplo caráter, características que são opostas entre si, como o seu lado bom e seu lado cruel, ela caracteriza-se como um herói problemático, classificandose assim como uma personagem esférica. Enfim, Agripa Vasconcelos estabelece dois parâmetros de descrições sobre Chica da Silva. Primeiro, Chica é descrita como uma mulher bondosa e sempre disposta a ajudar o próximo, à medida que a narrativa avança, é apresentada como uma mulher terrível, capaz de arquitetar planos diabólicos para aqueles que atrapalhem o seu caminho. E, ao longo da narrativa, suas descrições vão sendo mescladas conforme o objetivo de apresentar seus dois perfis, a fim de configurar e afirmar a construção de uma personagem multifacetada. 
O romance Xica da Silva foi escrito por João Felício dos Santos e teve sua primeira publicação em 1976. Ele foi escritor, jornalista e roteirista, com uma vasta quantidade de obras, entre elas: Ganga Zumba (1962), livro premiado pela Academia Brasileira de Letras; Carlota Joaquina (1968) e Margueira Amarga (1985). Destaca-se que o autor se ateve, em especial, à ficção histórica:

Sempre procurou abordar a história dos esquecidos, daqueles que foram excluídos à força pelos vencedores. Não sei de outro escritor brasileiro que tivesse um tão vasto conhecimento das coisas do país, não só na forma de sua cultura popular, como também na erudição de sua história (DIEGUES, apud SANTOS, 2017).

Cacá Diegues ainda reforça que o escritor haveria feito primeiramente o roteiro do filme sobre Chica e, somente após a sua conclusão, o livro Xica da Silva.

De forma geral, a narrativa se inicia com Chica ${ }^{8}$ sendo escrava do sargentomor; descrita com muito erotismo, praticava relações sexuais com o seu senhor e com o filho dele, Zezé. Em uma visita ao dono de Chica, o intendente Mucó se sente atraído por ela e tem interesse em comprá-la, porém, seu pedido é negado. Mas, com a chegada do contratador de diamantes João Fernandes de Oliveira, a escrava sente-se atraída pelo rapaz e deseja que ele seja seu próximo dono, como observamos em sua conversa com Zezé: “-Ele é formoso, Zezé! Ele é diferente do mundo! Até parece um príncipe, uai!" (SANTOS, 2007, p. 35).

O seu sentimento pelo contratador a faz cometer atitudes em busca da atenção dele, que logo se sente atraído pela escrava e a compra, tornando-a sua esposa. As cenas dos encontros sexuais entre eles são permeadas de tendências ao sadomasoquismo, evidenciando que Chica tivesse certo conhecimento sobre essa prática. Ela conquista sua carta de alforria e, de escrava se torna esposa de João Fernandes de Oliveira. O contratador, rendido de amores por Chica, procura realizar todos os desejos dela, por mais hiperbólicos que fossem, como construir um lago e uma nau para realizar o sonho dela de conhecer o mar.

Isso tudo causa inveja e revolta de muitas pessoas, principalmente em Dona Hortência, que também desejava João Fernandes, o que faz com que cheguem cartas anônimas de denúncias contra o contratador ao Marques de Pombal e até mesmo ao rei. Sendo assim, o Conde Valadares é enviado para cumprir um

\footnotetext{
${ }^{8}$ Embora o romance aqui estudado traga a grafia do nome da personagem de forma diferente, adotaremos aquela feita pelo escritor Agripa Vasconcelos, ou seja, a iniciada por Ch.
} 
mandado de prisão ao contratador João Fernandes de Oliveira. Esse mandado, porém, levou sete meses para ser cumprido. Com a prisão de seu amado, Chica ficou desprotegida e foi humilhada pelo povo. Sem direção para onde ir, procura um de seus antigos parceiros, Zezé, agora padre, ao fim do romance volta a ter relações sexuais com ela.

Diferentemente dos demais livros que retratam a história da ex-escrava Francisca da Silva Oliveira, a obra apresenta a grafia Xíca, ao invés de Chica; essa escolha do escritor se justifica na nota introdutória da primeira edição publicada do livro: "com X, como se escrevia no tempo em que viveu" (SANTOS, 1976, nota de introdução). Porém, seu livro não se diferencia apenas por isso, nele temos a construção de uma protagonista influenciada pelo estereótipo da mulher negra irresistível e sempre disposta sexualmente.

A imagem voluptuosa de Chica da Silva fantasiada por João Felício dos Santos tem ligações com a própria conjuntura sócio-histórica de escrita da obra literária, a década de 1970, momento histórico de forte inquietação política e cultural, onde assisti-se (sic) mobilizações libertárias com o desejo de uma maior liberação sexual que prometia "sacudir a velha moral, o velho mundo pudico, autoritário, patriarcal, arcaico" (GUILLEBAUD, 1999, p. 176) e que progressivamente fazia desvanecer a velha armadura social que defendia uma imagem normatizada para a mulher como casta, assexuada e abnegada ao lar. João Felício dos Santos, na década de 1970, concedeu a Chica da Silva a "alforria sexual", transformando-a na mulata fatal, luxuriosa e amoral (NASCIMENTOS, CALEIRO, 2015, p. 448).

Assim, temos contato com uma protagonista sexualmente liberta, que não esconde seus desejos carnais. As primeiras descrições de Chica são características soltas no trecho que a descrevem em uma cena de sexo com Zezé.

Acontecia que, alizinho, bem justamente no porão da casa, Xica, bata e saia não guardando dezessete anos de idade e sacanagens diversificadas, bastante demonstradas nos seus já dois mulatinhos tidos e havidos do padre que, agora, por imprestabilidade para seus carinhos inconclusos, de incubo, a venderá (barato até) ao sargento viúvo para dar-lhe cor à casa solteira de fêmea, ergueu-se num ímpeto quente bem da raça africana, como se desmanchasse, no chão, um bolo de muçuns.

Sacudindo a bata e abaixando a saia, largou zanga grossa, fingida nos dengos:

- Merda também! - O muxoxo descansado da zanga foi tão gracioso que Zezé, precisamente o filho caçula do sargento-mor, o que desde cedo andava de embolo com Xíca no porão escuro, puxou-lhe uma perna e mordeu sofregadamente, com força perversa, para que a ladina se deitasse de novo para renovadas fucinha, aparte da ira 
barulhenta do pai [...] Na terra amassada do porão, a mão do menino buscava, sem arte, renovadas inexperiências nas carnes da negra de rijas lombas...

Buscava e se ria. Se ria nervoso. Se ria e mordia aqui e ali onde calhase que Xica era doce e tinha sabor na pele aflorada. E Xica gostava de ser bem mordida, por isso, passava no corpo umburana. (SANTOS, 2007, p.13-14, grifos nossos).

Os trechos destacados mostram a escrava Chica da Silva associada à imagem sexualizada da mulher negra, pois como o escritor fala, ela possuía "sacanagens diversificadas", dessa maneira, notamos que ela, mesmo muito jovem, já havia sido submetida a violências que a levaram a ver a possibilidade de usar do corpo como uma ferramenta para obtenção de algum tipo de benefício, que na continuação no trecho evidencia-se ser algo "bem da raça africana". Desse modo, observamos que essa imagem da mulher negra sexualizada e racializada presente na personagem criada por João Felício dos Santos pode estar relacionada muito mais com aquilo apresentado na perspectiva colonial de Gilberto Freyre (1933), do que com os movimentos sócio-históricos da década de 1970.

Vale ressaltar que as representações sobre a mulata altamente
sensualizada remetem aos tempos coloniais, mas cada época
atualiza tais representações a sua maneira, assim como faz João
Felício dos Santos. Se o movimento da Revolução Sexual da década
de 1970 repercutiu para a escrita do romance de João Felício dos
Santos, influência maior foi recebida da obra Casa Grande e Senzala
(1933) de Gilberto Freyre que criou representações sobre a mulher
negra e tornou-se um marco referencial sobre as possibilidades de
pensamento de sua época. João Felício dos Santos é
contemporâneo de Gilberto Freyre e ao observar o contexto de
formação do romancista na década de 1930 e ao analisar a sua obra
literária percebe-se a influência das idéias sobre a mulher negra e
sobre a miscigenação que circulavam naquele contexto de
lançamento e discussão da obra de Gilberto Freyre (NASCIMENTO,
CALEIRO, 2015, p. 448).

Essa influência na construção da personagem evidencia-se na relação sintática estabelecida entre protagonista (Chica) e antagonista (Dona Hortênsia). Elas são descritas de forma oposta uma a outra, exemplo disso, é não haver o termo "bonita" associado à imagem de Chica, como nas descrições de Dona Hortênsia, como vemos: "a supradita senhora Dona Hortênsia (dos Fonte Garcia), bonita, travessa, caminho dos trinta, picada de sardas, sem teres e haveres nem muitos pesares, chegada a pôr chifres até no capeta (lourinha ademais)" (SANTOS, 2007, p.11). 
Por meio de um narrador heterodiegético, que tudo vê e tudo sabe, notamos que ambas as personagens têm suas sexualidades expostas, mas de maneiras diferentes, evidenciando o preconceito sobre a figura feminina "negra de rijas lombas". Pela análise estrutural actancial de Salvatore D'onofrio (1983) percebemos que a relação sintática ocorre na narrativa na existência de dois personagens principais que buscam um elemento em comum, ou seja, possuem o mesmo objeto de querer, nesse caso o contratador João Fernandes:

Em verdade, é possível perceber que Xica da Silva é construída durante todo o livro em contraste com a personagem Dona Hortênsia, que, nesse sentido, é entendida como personagem antagonista, ou, justamente, como "personagem contraste" (CANDIDO, 2014, p.92). Pensando nas personagens de fiç̧ão como aquelas construídas e identificáveis por sua função de ação nos enredos (PROPP apud SEGOLIN, 2006), temos que o contraste racial e estamental de Xica da Silva e Dona Hortênsia associado ao choque de temperamentos entre a personagem protagonista e a "personagem contraste" são recursos que reafirmam as caracteristicas de personalidade e ações da primeira. O contraste das "ambições, concepções de vida", "sensibilidade e caráter" (CANDIDO, 2014, p.92) da personagem protagonista e da personagem antagonista dão principalmente àquela "relevo mediante a um jogo de luz e sombra" (CANDIDO, 2014, p.92). Na trama podemos interpretar como "jogo de luz e sombra" os pilares de personalidade de cada uma dessas personagens, ora suprimidos ora revelados em contraste (NWABASILI, 2017, p. 55).

Desse modo, percebemos que o papel temático da protagonista e da antagonista é o mesmo, atrair homens por meio de seduções, pois Chica, por intermédio de sua sensualidade, usa o sexo como moeda de troca no relacionamento com seus donos, e Dona Hortênsia utiliza da sensualidade para atrair seus amantes. Porém, observa-se que seus atos sexuais são descritos com intensidades diferentes, carregados por estereótipos relacionados à construção da imagem feminina do século XVIII, cuja mulher branca é recatada e a mulher negra depravada. Primeiro, vejamos como o escritor trabalha a sexualidade de Chica ao descrever a cena em que o intendente pede para o sargento-mor, proprietário dela, para avaliar os dentes da escrava e, com sua permissão, ordenou a ela que se ajoelhasse em meio a suas pernas.

Divertida, sem esperar mais nada, Xica obedeceu correndo. Atirou-se entre os joelhos do intendente que tremiam pela delicia da expectativa e abriu bem a boca bonita uma graça com um olho no amo que se inquietava e enciumava e outro em Zezé, já bem refeito 
dos duros desgastes de há pouco, no porão. Ao mesmo tempo, Xica deu de se rir do jeito de dona Hortênsia olhar pro marido a meter-lhe, apressado que nem galo trepando, os dedos no roxo das gengivas antes de alisar-lhe as bochechas, o queixo, a carapinha asseada, o pescoço fino, as espáduas não tanto, descendo sempre mais até a concha dos braços guardadas em úmidas penugens, brilhando de recente aposto de suco de limão bravo, e os peitos carnudos, cheirosos, rombudos em acolhedoras cordialidades (SANTOS, 2007, p. 22).

Essa cena evidencia a protagonista Chica como uma mulher com apetite sexual aflorado, pois Chica não apenas acatou a ordem, como "correu" para cumprila, assim, o escritor reforça como a protagonista era disposta para aquele acontecimento. Ademais, além de o escritor descrever o intendente acariciando o corpo de Chica, ele faz questão de lembrar que essa mesma mulher, alguns minutos atrás, estava fazendo sexo com Zezé, o qual estava observando a situação, assim realçando sua libertinagem com o ato. Enfim, em público os seios de Chica são tocados, sem prudência ou respeito algum, a descrição é feita com a entonação desse toque como algo que a personagem desejasse, pois, o escritor utiliza o termo "acolhedoras cordialidades" ao descrever os seios de Chica, o que reflete nessa construção de uma mulher que estaria sempre à espera de tais carícias, ou algo a mais.

Dessa maneira, notamos que a construção da sexualidade da mulher negra ocorre de forma mais explícita, tanto na cena de sexo de Chica com Zezé como na cena das carícias do intendente, percebemos que os recursos textuais escolhidos por João Felício dos Santos evidenciam a protagonista como uma mulher libidinosa e lasciva. Porém suas escolhas textuais, ao retratar uma cena de sexo de Dona Hortênsia, são discrepantes as construídas para referendar as de Chica, como vemos:

Nem, naquela noite de começo de saudades, Hortênsia conseguiu se demorar nos ócios do costume, ócios gostosos de morna satisfação, esvaídos entre venturas na externa simples da Casa do Contrato. A mão distraída do major ainda passeando lembrados restos de orgasmos pelos seios muito brancos, graciosamente picados de sardas, a mulher alegou receios do povo... do marido que, por último, mordia-lhe a paciência com ciúmes tolos, em razão nenhuma! (SANTOS, 2007, p.190).

As descrições dos encontros sexuais entre Dona Hortênsia e seu amante constrói uma cena de sexo mais contida, ao comparar com as cenas mais picantes 
de Chica. Nesse trecho também podemos ver o contraste de personalidade entre as duas personagens, pois enquanto a sexualidade de Chica é exposta com algo "quente" e "sem limites", a de Dona Hortênsia é exposta como "morna" e há todo um respaldo com a demonstração de seu corpo, pois apenas são descritos seus seios e, após o ato, sem haver alguma cena de nudez explicita de seu corpo.

Observamos então que a relação de contraste das personagens ocorre de forma racializada, pois temos uma mulher negra e a outra branca, que refletem na relação entre si os valores do século XVIII a respeito da distinção entre elas. Ademais, analisemos que na narrativa ambas se sentem atraídas pelo contratador João Fernandes, porém enquanto Dona Hortênsia, mulher branca, demonstra sua atração e desejo, seus pensamentos eram conservadores, "trocar com ele olhares de poderá ser... conversarem a só, quem sabe? E quem sabe mesmo partirem os dois para úmidos e escaldantes rumos menos clareados" (SANTOS, 2007, p.27), assim, envia a ele uma carta anônima. Chica, por sua vez, usa seu corpo como meio de conquistá-lo, assim, invade o local em que João Fernandes estava em reunião com outros homens, inclusive na qual o seu dono participava, fingindo que havia sido agredida por Zezé, tudo para ter a sua atenção.

Com gestos apressados, o contratador mandou que os dois patuscos não interrompessem Xica e falou-lhe com ar muito amigo, pacientemente:

- Que lhe fez o malvado do Zezé, menina? O maroto tem ciúmes de quem?

Xica cresceu nas audácias. Sentindo terreno para pisar, respondeu desembaraços:

- De tudo! Ora, do povo, uai. Agora disse que o sinhô... - Parou como que encabulada, balançando as mãos como se não soubesse o que fazer com elas. - Por isso... só por causa daquele botão de rosa que the dei, me magoou aqui... mordeu aqui... beliscou aqui... mordeu aqui... beliscou aqui... pisou bem aqui... - deslumbrada com a atenção que provocava, muito maior do que imaginara, percebendo de longe o que dizia e o que não dizia o olhar quente do contratador, prosseguiu nadando em alegrias, mostrando o corpo pormenores, baixando e erguendo panos modestos, virando-se de lado... de frente... de costas...

Por fim, em passos quase dançados e volteios de mil graças, Xica ia rasgando aos poucos a roupa pouquinha:

- Olha veja só! Ontem, foi aqui! Anteontem aqui... Bem aqui, ta vendo? Ta vendo só como ta marcado? Hoje, só por causa de Vosmecê, me largou uma tapona na tábua dos peitos que me deixou toda roxa... Espia se não? Vê! Vê mesmo, uai! Num ta roxo? E me mordeu cá nos baixos... na popa da bunda! Nos dentro das coxas! Despida de todo, Xica acelerou passos e requebros. Já dançava francamente. Sem tirar os olhos do contratador, a ver até que ponto 
poderia chegar com segurança, começou a cantar um lundu de barrigada (SANTOS, 2007, p. 69-70).

Em vista disso percebemos que a construção da personagem Chica está atrelada a estereótipos sobre a mulher negra, pois observamos o contraste entre a descrição de uma mulher branca recatada e sexualmente "limpa", em confronto com uma mulher negra naturalmente lasciva e sexualmente selvagem, configurando-se a típica mulher devassa.

Além dos contrastes de cultura que enlaçam a construção da protagonista, percebemos que na narrativa inúmeras vezes seu nome aparece juntamente a termos depreciativos, como: "mulata-sestro-sexo", "Xica-filha-da-puta", "XicaLoucura", "Xica-Turbilhão", "Xica-Vingança”, "Xica-Foguete”, "Xica-Teatro", "Xica-deCheiro", "Xica-Perfídia", "Xica-Sensualidade", "Xica-Tormenta", "Xica-Toda-Cor", "Xica-Impassível-por-Gozação", "Xica-Mulata”, "Xica-Busca-pé”, "Xica-Rufada", "Xica-Infernal". Esses termos caracterizam a personagem na narrativa, porém, notam-se como são termos pejorativos, e muitos deles estão presentes na construção racializada da imagem da mulher negra, que por muitas vezes, tem a intenção de inferiorizá-la como mulher e por sua cor.

A personagem Chica, de João Felício dos Santos, é descrita pelo viés do erotismo, criando na narrativa uma esfera de teor sexual do começo ao fim. Era uma mulher muito sensual e atraente como podemos ver nos seguintes trechos: "... (Xica era de matar um homem!) ou demoras impróprias (Xica valia a pena...). "Xica, filhada-puta mais traiçoeira do que leite posto a ferver em fogo alto, realçava o macio enxuto de suas curvas em sortidos gingos de inocentes cores" (SANTOS, 2006, p. 20). Percebemos também que o escritor ao se utilizar de termos considerados palavrões, como "filha da puta", reforça a construção do estereótipo sexista relacionado à imagem da mulher negra.

A sexualidade da personagem aparece pela primeira vez na descrição de uma relação sexual entre ela e o Sargento-mor:

É que, se a cura ou o restabelecimento das forças não se desse já longe do alcance das právidas mãos da mulata terrível, senão ainda debaixo dos mais ardentes tapas e dentadas cruentas, por todo o corpo, complementos exigidos para a satisfação da libido originalíssima, sua vítima havia de retornar fatalmente à inconsciência total, após os mais complexos e renovados orgasmos (SANTOS, 2007, p. 46). 
Notamos com o trecho acima atos de Chica que apresentam sua sexualidade, pois ela é uma mulher que vai usar seu corpo para o seu prazer, o que quebra com a ideia de castidade, pureza e honra esperada para a mulher do século XVIII e preconizada pela moral cristã. Ademais, nota-se uma pulsão sexual da personagem nas descrições de seus encontros sexuais; além da passagem com o Sargento-mor, há outra com o contratador de diamantes:

João Fernandes é que, não obstante o costumeiro exercício em cruentos diários, berrava, se defendendo com unhas e dentes, das caricias infernais da mulata que, repetidas ao infinito, sem tréguas, se faziam um cristão chegar aos paroxismos do céu, atiravam-no, também e ao mesmo tempo, aos piores suplícios infernais (SANTOS, 2007, p.109).

E ainda: "Xica se atirou ao chão, agarrada a João Fernandes que ria-gemiachorava-gritava-protestava-esperneava-sofria-gozava..." (SANTOS, 2007, p.132). Por esse trecho, notamos que seu parceiro sentia sofrimento com os atos ao mesmo tempo em que estes provocavam prazer. O que é reforçado pela seguinte construção incomum do escritor "ria-gemia-chorava-gritava-protestava-esperneavasofria-gozava", que expressa a ideia de tudo o que o contratador sentia, um misto de sensações paradoxais; para tanto, o autor optou pela utilização do hífen, forjando uma palavra composta para designar o ato, que é único, porém repleto de variantes.

No caso da Chica da Silva, do romance homônimo, o escritor recorre a imagem da mulher atraente com forte apetite sexual, tão difundida na época, pois na visão dominante essa seria uma possível explicação para o relacionamento entre duas pessoas de classes e raças tão distintas. Considerando o escritor tratar-se do sobrinho do renomado historiador Joaquim Felício dos Santos, supõe-se que ele tenha lido o trabalho de seu tio a respeito de Francisca, seguindo-lhe a mesma linha ideológica. Júnia Furtano em entrevista concedida a Marco Antônio Corteleti afirma:

De acordo com Júnia, a ex-escrava tornou-se conhecida por sua crueldade e pelo grande apetite sexual graças ao livro Memórias do Distrito Diamantina, do século XIX, escrito por Joaquim Felício dos Santos. "A publicação faz de Chica a única negra a figurar em um registro histórico e o autor encontra no sexo e na perversidade os pretextos para uma escrava merecer tal destaque", diz (1998, p.01).

Com o trecho da entrevista, podemos observar que o historiador relaciona a imagem de Francisca ao sexo e à perversidade. Assim, buscando-se uma possível 
relação entre esses dados e a personagem ficcional, notam-se os dois itens arrolados em relação ao sadismo de Chica na sua descrição dentro da narrativa, pois a perversidade aparece no seu lado sádico evidente em suas relações sexuais, e sua sensualidade se faz presente em muitas das descrições feitas. Ademais, ressalta-se que o escritor João Felício dos Santos é sobrinho-neto de Joaquim Felício dos Santos, e realmente pode ter havido influência do trabalho de seu tio no seu. Porém, Nascimento e Caleiro (2015) enfatizam a seguinte discrepância entre ambos:

Diferentemente do seu predecessor, o célebre memorialista Joaquim Felício dos Santos, que rispidamente aponta Chica da Silva como tendo um aspecto físico desagradável; João Felício dos Santos, na década de 1970, reabilita a aparência de Chica da Silva a exornando com muita beleza, esbanjando graça e sensualidade em seu romance. (NASCIMENTO, CALEIRO, 2015, p. 447-448).

Dessa maneira, percebe-se que as obras dialogam ao trabalhar com o estereótipo da sexualização da mulher negra, porém se diferenciam na construção da imagem física de Chica da Silva.

Outro tópico que o escritor João Felício dos Santos é influenciado pela composição cultural do século XVIII é a ascensão social das mulheres escravas por meio do concubinato com homens brancos. Percebemos que por meio da personagem Chica, o escritor trabalha com o corpo da mulher em troca da ascensão, pois ele enfatiza que a todos os homens com quem ela praticava $o$ ato, ela pediu um par de sapatos brancos, que seria uma espécie de materialização da ascensão social que procurava. Assim, os primeiros a receberem esse pedido são Zezé e o seu pai, o sargento-mor, porém nenhum deles o acata, como vemos em uma conversa de Chica com Zezé: "E o sapato branco que você me prometeu? Todo mundo me promete um sapato branco... Teu pai também! É mesmo triste essa vida de cativa, ora porra!" (SANTOS, 2007, p. 31). Frustrada, a única espera que Chica vê em conseguir os sapatos é por meio do contratador João Fernandes de Oliveira, pois Zezé já havia comentado a ela que seria um homem muito rico. Assim, na primeira noite de sexo dos dois juntos, ela faz o pedido a João Fernandes.

Xica, as amêndoas negras dos olhos voltadas para as estrelas que se viam dali, enormes como rosas de luz, sentiu que não só havia conquistado sua carta de alforria, como ganho de presente seu 
primeiro escravo de verdade. E pediu, quase que como um sopro de flor:

-Tu me dá um sapato branco? (SANTOS, 2007, p.75).

O simples pedido da protagonista Chica em primeiro momento pode parecer bobo, porém, analisando historicamente a situação do Brasil escravagista, percebemos que o uso de sapatos por ex-escravos era um símbolo de ascensão social, pois apenas os senhores da elite branca usavam, enquanto os escravos andavam descalços.

Após o decreto de libertação dos escravizados negros, em 1888, no Brasil Colonial, os ex-escravizados que tinham pequenas economias guardadas procuravam ir as lojas de sapatos. Para os recém-libertos, poder andar com os pés calçados era o mesmo que se equiparar à dignidade dos seus antigos senhores, que usavam botas e borzeguins. Calçar os pés negros, "pouco acostumados a estar estreitados" (WISSENBACH apud COSTA, 2015), ou mesmo só comprar sapatos para caminhar com eles nas mãos, torna-se então o primeiro gesto genuíno de liberdade e exibicionismo dessa nova condição e das possibilidades de ascensão minima que ela permitia (NWABASILI, 2017, p. 63-64).

Diferente dos outros homens, João Fernandes de Oliveira faz questão de presenteá-la com os sapatos desejados. Dessa forma, encomenda de Portugal mais de vinte pares de sapatos, pois no arraial e redondezas não encontrou nenhum que servisse aos pés de Chica, "para o número dos pés de Xica, espalhados por dezoito anos de contato diário com as quinas do chão, não havia um só par em todo o Distrito" (SANTOS, 2007, p.79). Para NWABASILI (2017, p. 64) a dificuldade em encontrar sapatos que coubessem em Chica "pode ser entendida como mais uma alegoria, essa fazendo referência a dificuldade de ascensão material e aceitação social de uma concubina forra". Essa teoria é confirmada quando Chica é presenteada por João Fernandes de Oliveira com os sapatos e sua carta de alforria, porém, os sapatos acabam sendo o centro das atenções da protagonista.

[...] Aprovou o quadro e passou aos sapatos: ajoelhou-se outra vez, pegou delicadamente um pé pelo solado, o salto pra dentro, pra palma da mão. Mas teve um presságio: será que entraria? Tão fino o sapato, tão largos os pés? Foi Xica que fez quebrar a pergunta: com muita vaidade, sem vacilações, em gestos de asas, ofereceu-lhe os seus pés, já bem calçados na trama das meias.

O contratador ficou triste, prevendo o fracasso que, pelo que via, seria iminente. Tentou, mesmo assim, introduzir um dos pés no sapato branco. Foi custoso o começo! João Fernandes, coitado, decepcionado mais pela tristeza que poderia causar à sua mulata, 
forçava o sapato, arreganhava-Ihe as bordas, rompia o cetim, vergava-lhe a sola, suava, bufava, mas o sapato, já se deformando, não ia além do rude calcanhar, inchado nos rombos, rachado mui grosso.

Xica é que, soberana, certezas de força, não tomava fé da coisa. Se ria e, às vezes, por muito favor, inclinava a cabeça pra ver mas, só isso, nem mesmo ajudava com um esforcinho, pequeno que fosse.

Por fim... Ah! Deo gratia! Entrou um pé, sim. Viva! Que beleza! Bonito, não é mesmo? E João Fernandes, gozando vitória, partiu pro outro pé.

Novas lutas se travaram! Sem esmorecimentos, em novas tentativas e novos artifícios, o contratador decidiu calçar o outro pé.

Desta vez, mais difícil, talvez por cansaço, até pó de talco o contratador usou sobre a meia de seda brilhante...

Quando sentiu o outro calcanhar de Xica indiferente tomar acomodação na concha da calçadeira, apertou o peito do pé da mulata com força pra baixo. Xiquinha fez - Ai! Assim tu me machuca... tu me fere, uai! - , mas cheia de dengo, beijou a cabeça que tanta força fazia. O fato é que, de repente, escorregando no pó e na seda da meia, o pé assentou no talão do sapato.

João Fernandes se abriu num sorriso humilde; feliz pela Xica, esquecido da cena grotesca. Devagarinho, levou ao encontro de seus finos lábios os lábios negros e carnudos de Xica.

O beijo foi doce, sem hora e sem pressa, em sugados turbados porque atingindo o cume do amor. Fernandes se viu, nos olhos de Xica, no bojo redondo da lágrima mansa, regada em purezas de muita gratidão:

- Meu homem... que bom! - gemia a mulata. — Que lindo! É demais! - Os olhos de Xica comiam os sapatos. - Que quanta ventura... nem sei o que diga... Tô chorando, uai!

Se Xica chorava era de felicidade, uma primeira lágrima de fé no futuro, um primeiro sapato pros caminhos da vida...

- Meu homem... - e Xiquinha chorava ainda mais olhando pros pés. Erguendo-se do silhão, Xica pôs-se de pé.

Difícil tarefa! Rangendo nas solas, batendo nos saltos, o bico apertava! Doía nos pés, ardia nos lados... João Fernandes ajudou-a carinhosamente a dar alguns passos.

- Mulata querida! Agora, mulata, minha mulata, veja sua carta! Até já esquecia... - e passou-Ihe a alforria, em letra escorreita, chorando também de tanta ventura. - De agora em diante, menina, meu bem, você é tão livre como o papa ou o rei... como eu, talvez mais!

Xica se rindo, beijando o amante, nem se importou de olhar o papel:

- Ora, eu já era, meu amor querido! Já era desde quando Ihe dei aquela rosa... Senti a certeza que eu era só tua e que tu era só meu...

Mas foi só quando, atrevida, ao largar o braço de João Fernandes para dar seu primeiro passo, sozinha, calçada em sapatos, Xica sentiu-se realmente independente. Daquele momento em diante, seria uma senhora dama e a mulher mais poderosa de todo o Distrito.

Ah! - pensou ansiosa por suas vinganças. - Agora, sim! Agora é que essas brancudas coalhadas, cagonas de merda, hão de ver o diabo comigo nas proas. E eu não vou ter pena! (SANTOS, 2007, p.91-93). 
Assim, vemos que os dois presentes de João Fernandes a Chica da Silva são provas de seu amor a ela e de como estava submisso àquela paixão, pois ele mesmo fica de joelhos aos pés da protagonista para colocar o seu primeiro par de sapatos. Essa cena nos faz lembrar o conto da Cinderela, especificamente, do momento em que o príncipe coloca o sapatinho de cristal nos pés da Borralheira. Dessa maneira, o sapato, tanto no conto como no romance, constituem uma espécie de símbolo de ascensão social, e podemos enfatizar que essa passagem reforça que nesse momento Chica está deixando de ser uma escrava e passando a ser a "rainha" do Tejuco.

Ademais, o trecho que descreve o sofrimento do simples ato de calçar um sapato reforça a construção das dimensões de desigualdade social que o escritor busca representar em sua narrativa ao descrever a esfera colonial do século XVIII. Outro aspecto importante do trecho é o momento que Chica anda sozinha de sapatos e realmente sente que estava livre do mundo da escravidão, não pelo papel da alforria, mas por ter acesso a indumentárias usadas apenas por mulheres brancas da elite.

Dessa maneira, a personagem vai apresentar pensamentos e ações extravagantes como forma de vingar-se da sociedade que tanto the fez mal, assim, passa a se exibir "vestida em brocados de longos bordados, a saia, enfestada de franjas, pesada com tudo de avio da Europa" (SANTOS, 2007, p.89).

Além de possuir uma luxuosa moradia, "a verdade é que a nova chácara de Xica-Anfitriã era realmente um magnífico castelo" (SANTOS, 2007, p.128), Chica passa a promover grandes saraus e tem seu pedido mais extravagante da narrativa acatado por João Fernandes: a construção de um navio em seu quintal, "Faz um lago bem grande e... pronto! O mar! Depois, manda fazer um navio de velas, com marinheiros e tudo" (SANTOS, 2007, p.131), e, assim se fez sua vontade: "Logo depois disso, foi que se deu a inauguração da fantástica galera de Xica, com marinheiros a bordo e todos os mais repiquetes das exigências surdas e absurdas da estrídula mulata" (Idem, p.142).

O estilo de vida da ex-escrava incomoda a sociedade local, que achava um desrespeito uma mulher mulata exibir-se com tanta grandeza para eles. Assim, inúmeras denúncias do relacionamento entre Chica e João Fernandes são feitas por meio de Dona Hortênsia à corte, essa ordena a prisão do contratador por supostas 
irregularidades do contrato. Em decorrência disso, Chica entra em decadência e perde tudo, pois seu acesso ao luxo era por meio da relação com o contratador. Ao fim, precisa usar seu corpo como moeda de troca e procura Zezé. Ele havia se tornado padre, e mesmo assim, rende-se aos encantos e seduções de Xíca, pois no período colonial era comum o concubinato com padres. Assim, Chica torna-se novamente uma mulher da "ralé", e Dona Hortênsia sente-se vingada.

A personagem Chica da Silva de João Felício dos Santos na distinção de Forster de "personagem planas" e "personagens esféricas" classifica-se como personagem plana com apenas o início de uma curva à personagem esférica. $O$ início dessa curva ocorre quando além de sua sexualidade explícita passa a ser extravagante, porém essa característica somática em sua construção não a desvincula da classificação de personagem plana, pois percebe-se que todo o seu eixo sintático está na construção de uma mulher sexualizada.

As personagens planas eram chamadas temperamentos (humours) no século XVII, e são por vezes chamadas tipos, por vezes caricaturas. Na sua forma mais pura, são construídas em torno de uma única idéia ou qualidade; quando há mais de um fator neles, temos o começo de uma curva em direção à esfera. A personagem realmente plana pode ser expressa numa frase, como: 'Nunca hei de deixar Mr. Micawber'. Aí está Mrs. Micawber. Ela diz que não deixará Mr. Micawber; de fato não deixa, nisso está ela." Tais personagens "são facilmente reconhecíveis sempre que surgem"; "são, em seguida, facilmente lembradas pelo leitor. Permanecem inalteradas no espírito porque não mudam com as circunstâncias (CANDIDO, 2017, p.46-47).

Ademais, pela análise do papel temático de Salvatore D’onofrio (1983, p.58), percebemos que a personagem não nos surpreende em momento algum, como no caso de uma personagem esférica, aqui a personagem "marcada do início e para sempre com traços identificadores", assim, seu papel temático apenas ocorre em torno da mulher negra sexualizada.

Enfim, entendemos que a protagonista da obra Xíca da Silva, de João Felício dos Santos, é construída por meio de influências da imagem da mulher negra estereotipada sexualmente, que seria "fogosa", "explicita" e "lasciva". Essa imagem foi iniciada durante o Brasil colonial como forma de depreciar a imagem da mulher escravizada, que possuía uma sexualidade explicita, não por escolha, mas por imposição do papel de escravizada, mas que feria os padrões de conduta social e moral impostos pela Igreja católica. 


\subsection{CHICA DA SILVA: ROMANCE DE UMA VIDA, DE JOYCE RIBEIRO (2016)}

O romance de Joyce Ribeiro é a obra mais recente sobre Chica da Silva, com sua primeira publicação em 2016. A escritora é jornalista e ativista dos direitos dos negros e mulheres, colaboração que a fez receber premiações, entre elas, o Troféu Raça Negra e o Camélia da Liberdade, da ONG CEAP (Centro de Articulação de Populações Marginalizadas).

Sua preocupação com a representatividade da mulher negra na literatura é perceptível pelo seu único romance publicado, que se intitula Chica da SilvaRomance de uma vida, obra na qual a escritora busca desmistificar alguns estereótipos relacionados à imagem da emblemática Francisca da Silva, que viveu durante o século XVIII, como vemos em suas palavras no prefácio de sua obra:

Muito diferente da imagem de mulher excêntrica, escandalosa e amoral que foi repassada ao longo dos anos, a verdadeira Chica da Silva tem outros contornos que, aos poucos, vão sendo revelados. É sob essa luz, clara e ampla, que conto a sua história (RIBEIRO, 2016, p.7).

Nesse contexto, Joyce Ribeiro em seu prefácio nos apresenta a sua visão sobre a pessoa histórica de Francisca da Silva, ressaltando a existência de uma imagem estereotipada e preconceituosa, construída de forma equivocada por críticos anteriores, com a qual ela não concorda. Assim, a escritora expressa sua opinião sobre quem foi Chica da Silva em nossa sociedade durante o século XVIII:

A Chica da Silva reconstituída era forte. Decidida. Jamais se curvou à servidão que se esperava das mulheres de sua época. E não só as negras, mas também às brancas, era imposta uma autoridade que tinham de acatar, fosse a do pai ou a do marido. Nem mesmo o homem com quem dividiram a vida e os filhos podiam escolher. Chica, na contramão dos costumes, era livre por natureza. Não por acaso bem cedo conquistou a alforria, como uma dádiva do homem com quem viveu mais de uma década e que jamais se casou com outra, mesmo quando foi obrigado a deixá-la, para resolver, em Portugal, difíceis problemas de herança (RIBEIRO, 2016, p.8).

Dessa maneira, percebemos que Joyce Ribeiro vê na pessoa histórica Chica da Silva uma mulher que transgrediu não apenas as regras sociais referentes a sua cor de pele, mas também as regras existentes quanto ao seu gênero, pois ela conquistou um espaço social maior que as mulheres brancas que não carregavam o 
peso da escravidão em suas imagens. Ademais, além de transgredir todas as regras sociais vigentes, Chica conquistou o respeito da sociedade tejucana de sua epóca.

Por fim, a escritora explicita o seu objetivo ao escrever a obra ficcional sobre a emblemática Chica da Silva:

\begin{abstract}
Meu objetivo com este livro é mostrar o poder transformador da confiança em nós mesmas, que gerou frutos até em uma época em que a valorização feminina sequer existia, e a certeza de que somos donas de nossas histórias, o que pode provocar reviravoltas, mudar os rumos de comunidades e países (RIBEIRO, 2016, p.10).
\end{abstract}

Desse modo, por meio do prefácio conhecemos a visão da escritora sobre a temática trabalhada em sua obra e algumas de suas intenções ao compor sua narrativa.

A narração da obra de Joyce Ribeiro é feita por meio de um narrador heterodiegético, e se diferencia das obras anteriores ao relatar os acontecimentos de forma cronologicamente inversa, dividida em prólogo e oito capítulos, a narrativa se inicia com a partida do contratador João Fernandes de Oliveira para Portugal, e Chica ficando devastada com o ocorrido, assim, ela pensa em como reunirá forças para continuar as suas tarefas e obrigações cotidianas e esperar a volta de seu amado.

Após essa parte, inicia-se o primeiro capítulo que faz uma retrospectiva da vida de Chica, desde o momento de seu nascimento ao primeiro encontro com o contratador de diamantes. Assim, o fluxo na narrativa vai fornecendo informações dos anos de casamento entre Chica da Silva e o contratador João Fernandes de Oliveira, resultando em uma imensa prole de treze filhos.

$\mathrm{Na}$ sequência, a narrativa volta ao presente dos fatos, mostrando como os dois lados se sentem com a separação e qual o motivo dela, o de uma batalha entre o contratador e sua madrasta pela herança deixada com a morte de seu pai. Com o passar dos primeiros anos de separação, João Fernandes de Oliveira recebe o direito total à herança e Chica da Silva está totalmente dedicada a criar os filhos e manter sua posição social, nunca perdendo as esperanças em relação à volta de seu amado ao Arraial do Tejuco. Outros problemas, porém, vão surgindo em Portugal ao contratador, entre eles um severo problema de saúde que afeta João Fernandes de Oliveira e acaba ocasionando sua morte, acabando com as esperanças de Chica de um dia se encontrarem novamente. Dessa maneira, a 
protagonista passa a viver o luto e cada vez se restringe ao convívio social com a sociedade do Tejuco. Ao fim, morre e recebe atos fúnebres e enterro de direito à elite branca, devido a sua posição e respeito social que adquiriu com os anos de vida no Arraial.

$\mathrm{Na}$ narrativa é notável que a ordem cronologicamente escolhida dos fatos esteja relacionada à construção da personagem principal, Chica da Silva, pois a escritora mostra ao leitor que a personagem estava predestinada, desde o seu nascimento, a viver a escravidão, como fato "natural" para a época, mas contra o qual, justamente, Chica irá lutar, amancebando-se com o homem branco a fim de garantir a sua liberdade e uma vida confortável. "A escrava Maria da Costa sente as dores do parto na senzala, não muito longe da igreja, e dá à luz uma menina, já condenada ao cativeiro" (RIBEIRO, 2016, p.24). Assim, desde pequena precisa aprender o seu papel social, o da submissão.

Nada afeita à preguiça, ela vai crescendo sem se queixar do cativeiro, mas presta atenção a tudo o que se passa ao seu redor. Aprende pela observação da realidade que pode mudar esse destino, como fazem muitas escravas envolvidas com homens brancos, com quem vivem e têm filhos. Não que isso implique união oficial, algo proibido pela Coroa Portuguesa, que só admite matrimônios entre pessoas do mesmo patamar social. Assim, a ela, Chica só restaria o futuro de unir-se a um escravo. Não é o que almeja (RIBEIRO, 2016, p. 28).

Com o trecho acima, notamos que mesmo na situação de escrava, Chica almeja um concubinato, pois na época era o único meio para uma espécie de ascensão social da mulher negra, que não deixava de ser escrava, mas talvez, por meio do ato de deitar-se com o seu proprietário, ela poderia usufruir de condições melhores de sobrevivência. "Até porque, com o passar do tempo, começa a atrair atenção, sobretudo pela aparência naturalmente sedutora. É uma jovem bela e saudável, com atrevimento no olhar e atraente movimento dos quadris" (RIBEIRO, 2016, p. 28).

Essa é a primeira descrição física da personagem, e é o recurso por meio do qual a personagem usa para conseguir o concubinato. Primeiramente, com o médico Manuel Pires Sardinha e, posteriormente, com o desembargador e contratador João Fernandes de Oliveira. Ademais, "[...] deitar-se com seu senhor faz parte das tarefas que cabem às escravas, da mesma forma que lavar roupa na beira do rio ou buscar água fresca e transparente na fonte" (RIBEIRO, 2016, p. 30). 
A protagonista é sempre descrita como uma mulher "de belas feições e sedutora aparência" (RIBEIRO, 2016, p. 39). Essa é a justificativa da narrativa para tal encanto da parte do contratador João Fernandes de Oliveira. Ademais, a personalidade de Chica da Silva é marcante desde o primeiro encontro entre eles, como vemos:

Contudo, no momento em que o desembargador vê Francisca, já como seu dono, percebe que ela não se intimida nem se encolhe. Nada de olhos fixos no chão, como quem se desculpa pela origem, pela pele escura, pelos cabelos fartos sem movimento nem lisura. Ela o encara, sem desafio, mas com viva curiosidade. Observa aquele a quem passa a pertencer como um objeto, uma cadeira, uma cômoda, um animal de carga. E não desgosta (RIBEIRO, 2016, p.39, grifos nossos).

Observa-se, nas partes destacadas, a evidência de que a autora apresenta uma personalidade à Chica de forma a colocá-la no controle da situação, assim, ela não se sente submissa, atitude esperada de uma escrava na situação dela, mas vê João Fernandes como um objeto - o uso deste termo deixa claro a intenção, ao menos no primeiro momento, que Chica tem em relação ao contratador - ou seja, ele é um meio para se alcançar um objetivo maior. Dessa maneira, no primeiro dia ao seu lado, eles mantêm relações sexuais.

E Chica sente, talvez pela primeira vez, como é ser tratada de um jeito diferente. $E$ que, se fazer amor é bom, como ele é muito melhor. Sem pressa e com uma intensidade que dá vontade de repetir. Eles são jovens e belos, nessa entrega que se manifesta em sussurros, suspiros, risadas. Ambos se completam, com uma alegria que transforma $\mathrm{o}$ ato em brincadeira de gente grande. E sem nenhuma culpa. Ao contrário, prazer infinito (RIBEIRO, 2016, p.41).

O trecho acima evidencia que o ato de prazer entre João Fernandes e Chica não é visto por ela como algo negativo, pois ambos sentem prazer com o ocorrido. Ademais, a partir desse momento, na narrativa Chica passa a viver o papel de uma esposa, dormindo no mesmo quarto que o amado e assumida socialmente por ele, porém, notamos que o ato de ele manter relações sexuais com ela desde o primeiro dia de sua compra é romantizado pela escritora, a fim de desfazer a ideia da mulher negra vista como objeto sexual. Ademais, João Fernandes por meio de suas atitudes procura provar a sua amada que suas intenções eram as melhores. Desse modo, com pouco tempo de comprada, João Fernandes de Oliveira a presenteia com a sua alforria, algo incomum na época. 
Nada mais eloqüente do que esse ato, ao mesmo tempo singelo e grandioso. Escolher o dia de Natal como aquele em que sua companheira vem à luz como uma mulher livre da escravidão. $O$ simbolismo é mais profundo, porque Chica não tem de pagar por isso, como acontece com outras mulheres em semelhante situação. Fica livre da senzala social como um presente a que tem direito, aos olhos de quem conheceu como seu segundo senhor. Essa é a mensagem que ele passa, a do merecimento. Quem sabe até como um pedido de desculpas por não poder assumi-la como a esposa que é, de fato. Todas as conjecturas são possíveis aos olhos de quem vive no Tejuco (RIBEIRO, 2016, p. 44).

Por esse viés, na narrativa é notável que a relação entre o casal rompe com as bases morais e sociais do século XVIII, pois uma relação entre classes tão distintas, como o caso dos dois, não era permitida ser oficializada pela celebração matrimonial da Igreja. Entretanto, João Fernandes de Oliveira assume perante a sociedade, principalmente a elite branca, Chica da Silva como sua esposa, "Como não pode desposar a mãe de sua filha, João Fernandes trata de viver com ela como se o matrimônio fosse de verdade" (RIBEIRO, 2016, p.50). Algo difícil de compreender no período em questão, o relacionamento entre uma ex-escrava e um dos homens mais importantes do período Colonial. Porém, durante a narrativa, nesse momento Chica passa a ser respeitada na sociedade local como esposa dele.

A relação entre as duas personagens principais resulta em uma prole numerosa de treze filhos, sendo composta em sua maioria por meninas, algo que não era visto como vantajoso, porém João Fernandes não se preocupava com isso. Apesar de seus filhos não terem a paternidade legitimada em seus nascimentos, ele faz isso ao colocá-los todos em sua herança antes de partir para Portugal. Esses são motivos que comprovam a união estável entre eles, ademais, com a separação necessária do casal, ambos não estabelecem união estável com outros parceiros.

Dessa maneira, estabelecendo que João Fernandes de Oliveira e Chica da Silva possuíam uma união estável e respeitosa por ambas as partes, a escritora constrói sua protagonista sobre duas características especificas, a Chica da Silva de Joyce Ribeiro é descrita como uma esposa dedicada e uma mãe zelosa. Assim, primeiramente, a escritora a destaca como uma esposa dedicada, pois procura agir como esperado de uma verdadeira esposa da elite branca, assim, logo de início de sua relação dedica-se a gerar seus herdeiros, destinando a amamentação às escravas compradas para essa função. 
Essa é uma tarefa sempre delegada a uma cativa recém-parida, que passa os meses seguintes a alimentar seu rebento e o da patroa, no caso de Chica, a menina Francisca de Paula. Assim, as esposas ficam livres desse cuidado, não porque lhe pareça pesado ou dele queiram se livrar, mas para que possam estar concentradas na missão de engravidar novamente (RIBEIRO, 2016, p.48-49).

A preocupação de Chica em possuir escravas com a finalidade de amamentação comprova sua preocupação em garantir inúmeros herdeiros ao seu esposo, já que a missão da maternidade era muito difícil na época, pois eram muitos os empecilhos encontrados, como a risco de morte no parto da mãe e o bebê, como também as inúmeras enfermidades que poderiam ocasionar o óbito infantil no primeiro ano de vida e o período de resguardo de três meses para garantir a saúde da mulher para gerar o próximo filho.

Acostumada a viver em casas com todo esse aparato, Chica se
movimenta com facilidade pelo ambiente, agora não como serviçal.
E, aos poucos, percebe que é melhor absorver os costumes de gente
branca. É uma tendência entre as mulheres que, como ela, sobem na
escala social, mesmo sem o reconhecimento legal. Parece - e está -
muito distante do tempo em que partilhava a senzala com o povo de
sua origem, mesmo que tenha conquistado a alforria há pouco. A
chegada da ama de leite para a recém-nascida Francisca é um
marco nessa transformação. Seu destino não é nutrir, mas parir.
Compreende perfeitamente e aceita a missão, como tudo o que já
viveu antes. Só que agora com muito mais leveza (RIBEIRO, 2016,
p. 53).

Ademais, Chica da Silva constrói em sua vida hábitos típicos das senhoras da elite branca, "que no recesso do lar prefere trajar-se com o conforto e a simplicidade das roupas feitas de chita" (RIBEIRO, 2016, p.51). Entretanto, para eventos sociais e missas dominicais, "Não Ihe faltam saias vibrantes, corpetes ajustados, anáguas volumosas, chapéus extravagantes e capas luxuosas para se proteger da friagem, quando saem de casa muito cedo" (RIBEIRO, 2016, p. 51) Ademais, possui "sapatos de seda, ornamentos com pedrarias, laços ou chamativas fivelas de prata" (Idem, p. 51), e jóias de ouro. Isso, com a finalidade de garantir que esteja apropriada em ocasiões sociais como se espera da esposa de um contratador de diamantes.

$\mathrm{Na}$ vida intima do casal a protagonista também se mostra dedicada, entretanto, "Ir para a cama está longe de ser um sacrifício ou obrigação, como 
acontece com as mulheres brancas sem amor nem paixão. Vive noites de prazer e dias de leveza" (RIBEIRO, 2016, p. 54). Desse modo, notamos que a personagem Chica da Silva em vários momentos narrativos é ressaltada com uma esposa dedicada e zelosa em todos os aspectos institucionalizados socialmente às mulheres brancas, aos quais ela adere, assim, dedicando-se plenamente na maternidade, na sexualidade e, o mais importante para sua condição na época, na sua imagem social.

A outra característica marcante em sua construção é o fato de mostrar-se como uma mãe amorosa e zelosa, pois Chica da Silva dedica-se incansavelmente aos filhos, a fim de garantir um futuro promissor e que apague suas origens em relação à escravização e à tonalidade de sua pele. Seu empenho como mãe é evidenciado desde o seu primeiro filho, fruto da relação com o seu ex-proprietário doutor Manuel Pires Sardinha, o qual ela carregava para todos os lados enquanto era escrava, e que durante sua compra por João Fernandes o leva junto, "um mulatinho viçoso e esperto, muito bem cuidado pela jovem mãe" (RIBEIRO, 2016, p. 39). Com as filhas internadas em conventos com a finalidade de receber educação de qualidade, Chica mãe não mede esforços em visitá-las, principalmente quando adoecem:

Chica não se conforma em ficar distante de uma filha doente. Quer se assegurar de que tudo seja feito para que se restabeleça. Ela mesma acompanha tudo, atenta aos menores detalhes, observando a preparação dos ungüentos e dos chás indicados. Não descansa até que a saúde esteja de volta. Naquela família ninguém é deixado à própria sorte. Todos contam com respaldo e carinho, além de boa alimentação (RIBEIRO, 2016, p.113).

Além das preocupações maternas em cuidar bem dos filhos, Chica preocupava-se muito com o branqueamento de sua prole, apagando a origem de seus filhos, pois só assim os meninos conseguiriam cargos de prestígio e as filhas bons casamentos, já que para os afrosdecentes esses lugares eram negados.

Os filhos que ficaram, educados e prontos para novos desafios, quem sabe também vão mudar para o Reino. As meninas são letradas. Quem sabe serão encaminhadas para casamentos de verdade, não amancebadas como a mãe. Toda a prole de alguma forma estará livre das origens que poderiam reduzir suas perspectivas vida. Ela vai se empenhar para que os vestígios da escravidão desapareçam nos atalhos de burocracia e da rede de 
influência que os poderosos tecem com esmero. Sabe que seu amor fará o mesmo, enquanto estiver no Reino (RIBEIRO, 2016, p. 21).

Dessa maneira, observamos que a personagem se empenha em garantir um futuro de qualidade para os seus filhos, apagando de documentos uma escrava como mãe deles, isso é feito somente em Portugal, pois como a viagem era longa os fiscais não faziam visitas para conferir a veracidade das informações. E eram necessários manter estreitas relações com pessoas que detinham poder em suas mãos, assim, Chica dedicava-se em ter uma vida social ativa.

Além dos compromissos sociais, entre jantares, festas, saraus,
sessões de teatro e ópera, o contratador se dedicava às atividades
religiosas, que não se restringem à obrigatória missa dominical, às
confissões e às comunhões, e à liturgia de grandes festas, como
Páscoa e Natal. Participa das tradicionais irmandades, instituições
leigas que se responsabilizavam por eventos do calendário católico e
seus diferentes ritos, e cuidavam até mesmo da construção de
igrejas (RIBEIRO, 2016, p. 60).

Chica sabia que para conseguir almejar o branqueamento de seus filhos precisava estabelecer uma rede de contatos com os sujeitos integrantes da elite branca tejucana, assim, quando precisasse um amigo jamais negaria um favor a ela, e principalmente, ao seu esposo. Entretanto, mesmo com a partida de seu amado, o respeito a ela como senhora é notório no arraial.

Não por acaso conta com o respeito de quem faz a diferença, de fato no arraial. É uma esposa de direito e que faz por merecer esse status. Ninguém ousa confrontá-la ou tratá-la com menos deferência do que a devida às senhoras de pele branca. Nem mesmo os religiosos, que a recebem para os ofícios domingueiros e festas de guarda sem nenhum constrangimento. É, para todos os efeitos, a mulher do desembargador, passe o tempo que passe sem que ele retorne (RIBEIRO, 2016, p.110).

O respeito que toda a elite social e a própria Igreja tinha em relação à protagonista é inegável ao fim da narrativa, pois, com a sua morte, o seu corpo recebe todos os atos fúnebres destinados à elite local, iniciando pelo sacramento da extrema-unção, e recebendo uma missa de corpo presente, "um privilégio concedido apenas a quem tem relevância ímpar na comunidade" (RIBEIRO, 2016, p.184). Ademais, inúmeras pessoas compareceram à sua celebração, por fim:

No sermão, suas virtudes são destacadas, bem como a dedicação aos herdeiros, divididos entre Brasil e Portugal. Entre seus filhos, 
muitos têm relevo e brilho próprio. O sepultamento dos restos mortais de Chica da Silva é no interior da igreja da Irmandade de São Francisco de Assis, à qual ela pertencia, embora fosse um núcleo de brancos abastados. Só estes, aliás, tinham o direito de manter tumbas ali dentro. De alguma maneira, é oferecido a ela certo branqueamento, ainda que póstumo, embora jamais tenha ocultado sua origem (RIBEIRO, 2016, p. 185).

Por fim, o desfecho da história revela o branqueamento que Chica da Silva consegue para sua prole e o respeito para si, evidenciando as características notadas desde o início de sua aparição na narrativa, que é de uma esposa zelosa e mãe dedicada, ademais, a protagonista se mostra uma mulher forte e de grande posição social. Dessa maneira, a personagem de Joyce Ribeiro enquadra-se na classificação de Foster de personagem plana.

Desse modo, justifica-se a classificação da personagem Chica da Silva como plana, considerando que o eixo da narrativa está estabelecido sobre as características de boa e esposa e mãe, assim, essas são as características que acompanham a personagem do início ao fim da narrativa. Não causam surpresas em relação a seu desenvolvimento na narrativa, apenas suas construções narrativas afirmam e reforçam sua construção em torno de qualidades que a exaltam como esposa e mãe. Assim, seu papel temático na narrativa nos apresenta uma personagem "marcada do início e para sempre com traços identificadores" (D'ONOFRIO, 1983, p.58).

Por meio da análise estrutural de Salvatore D'onofrio (1983) ele ressalta que a estrutura actancial da narrativa ocorre pela relação sujeito vs objeto, assim, na narrativa de Joyce Ribeiro a relação se estabelece entre Chica da Silva e a volta de João Fernandes de Oliveira, pois, desde a sua partida, é o que a personagem mais deseja. Por meio dessa constatação entende-se que é esse desejo de Chica que a impulsiona a continuar seus afazeres sozinha e da melhor forma possível, mas sempre aguardando o dia do retorno de seu amado.

Outro aspecto notável na protagonista está em que não há progressão de suas ações na narrativa, pois ela não comete atos em busca de seu "objeto de querer", ou seja, em busca de fazer acontecer a volta de João Fernandes de Oliveira, o que é justificado na narrativa, evidenciando que não haveria o que ela fazer, a não ser esperar que um dia voltasse. Ademais: 
O ator, seja ele caracterizado por uma qualificação típica ou posicionalmente, para que efetue a sua "performance", isto é, para que possa ser o sujeito de ações dinâmicas, deve previamente adquirir a "competência" especifica. Esta competência é-lhe conferida através de três modalidades: 1) a modalidade do "querer": o sujeito, antes de mais nada, deve ser consciente daquilo que realmente deseja e demonstrar a vontade de querer conseguir o objeto valor; 2) a modalidade do "saber": ele deve saber onde se encontra o objeto desejado e o que fazer para alcançá-lo; 3) a modalidade do "poder": o sujeito da ação deve possuir os meios adequados para conseguir apossar-se do objeto-valor (D'ONOFRIO, 1983, p. 58).

Portanto, por meio do esquema de competências notamos que a Chica da Silva de Joyce Ribeiro apenas possui a primeira competência, a do "querer", pois ela sabe realmente o que deseja, porém durante toda a narrativa apenas deseja seu objeto-valor, sem desenvolver as competências do "saber" e do "poder", como forma de alcançá-lo. Desse modo, concluímos que a protagonista é criada apenas sobre um eixo sintático-semântico, e não desenvolve ações actacionais de forma ativa no enredo, a não ser esperar, que talvez um dia tenha novamente ao seu conforto João Fernandes de Oliveira, entretanto não é o que ocorre, pois com a sua morte, o reencontro nunca ocorre. 


\section{CONCLUSÃO}

Os três romances trabalham com a interpretação da pessoa histórica de Francisca da Silva para construir suas personagens principais. Dessa maneira, para a literatura comparada é evidente que obras de diferentes escritores que trabalham com um mesmo elemento possuem semelhanças e discrepâncias entre si. Assim, os romances Chica que manda (1966), de Agripa Vaconcelos, Xíca da Silva (1976), de João Felício dos Santos e Chica da Silva - romance de uma vida (2016), de Joyce Ribeiro, possuem pontos de aproximação e de diferença entre si.

O primeiro ponto de semelhança entre os três romances está na escolha da narração, pois todos possuem um narrador heterodiegético que vê e sabe de tudo o que se passa com as personagens, no seu mais profundo íntimo. Para Brait (1985), a apresentação da personagem por um narrador que está fora da história é um recurso muito antigo e eficaz, dependendo da habilidade do escritor que o maneja. Em um certo sentido, é um artifício primeiro, uma manifestação quase espontânea da tentativa de criar uma história que deve ganhar a credibilidade do leitor.

Em vista disso, na obra de João Felício dos Santos (2007), temos o acesso, promovido pela ficção, aos encontros sexuais entre Chica e João Fernandes, com detalhes, como no seguinte trecho: "rolavam na maior prosmicuidade pelos tapetes, já manchados, pelas almofadas já úmidas, e até pelo chão puro, já pegajoso em suspeitos líquidos nas tábuas enormes de jacarandá" (SANTOS, 2007, p. 109). Na obra de Vasconcelos (2010), por meio do narrador é que temos contato com os crimes encomendados por Chica, pois há detalhes que só ela poderia saber e perscrutar, mas que o narrador desnuda aos olhos do leitor. E por fim, na obra de Joyce Ribeiro (2016), o narrador nos proporciona contato com os momentos de dor e frustrações de Chica relacionados à ausência de João Fernandes de Oliveira, pois ela não mostrava essa sua fraqueza para as pessoas, seus momentos de dor eram dentro de seu quarto sozinha, assim, só os conhecemos por meio do narrador.

Como Brait ressalta, "o narrador em terceira pessoa simula um registro contínuo, focalizando a personagem nos momentos precisos que interessam ao andamento da história e à materialização dos seres que a vivem" (BRAIT, 1985, p. 56). Assim, os recursos textuais do narrador são de grande valia nas narrativas, no processo de construção e veracidade das personagens. 
O desfecho entre o casal apaixonado se assemelha e se diferencia em alguns detalhes. Nas três narrativas ocorre a separação imposta para Chica da Silva e o contratador João Fernandes de Oliveira, porém os motivos que resultam nesse momento são distintos. Na obra de Agripa Vasconcelos (2010), o motivo que leva o contratador a voltar para Portugal está em uma suposta reunião com a corte para discutir detalhes do seu contrato, no entanto, quando está lá descobre que o ato não passa de uma armadilha e é acusado de irregularidades. Ele paga uma alta fiança para ter sua liberdade, mas logo se depara com outra situação, a disputa pela herança de seu pai, assim, após anos de batalha, ele vence a disputa, mas adoece e acaba entrando em óbito.

Já na obra de João Felício dos Santos (2007), a separação ocorre por um mandado de prisão do conde Valadares motivado por irregularidades no andamento do contrato, assim, o contratador é preso e levado para Portugal. E, por fim, na obra de Joyce Ribeiro (2016) João Fernandes de Oliveira volta para Portugal para a disputa da herança de seu pai, que leva anos, e acaba adoecendo e falecendo, dessa maneira, nunca mais revê Chica da Silva.

As obras se diferenciam entre si nos anos que foram publicadas, sendo a obra de Agripa Vasconcelos publicada em 1966; a obra de João Felício dos Santos publicada em 1976, e a obra de Joyce Ribeiro publicado em 2016.

Desse modo, na narrativa de Agripa Vasconcelos percebemos que quando Chica torna-se publicamente esposa de João Fernandes de Oliveira, ela precisa adaptar-se às regras sociais dos brancos. Na narrativa sugere-se que suas atitudes de violência contra seus escravos seriam algo normal praticado pelos proprietários na época. A narrativa de João Felício dos Santos (2007), expressa o estereótipo da mulher negra "fogosa", ou seja, que buscava a prática sexual como uma necessidade de seduzir a todos, para ficarem cativos às suas vontades. A narrativa de Joyce Ribeiro (2016), sendo a obra mais recente e possuindo um olhar feminino, apresenta uma visão diferente, assim, Chica seria uma mulher que transgrediu as regras sociais do período, tanto as relacionadas com sua cor, como também com sua condição de sujeito feminino. Entretanto, ela é apresentada como uma zelosa esposa e mãe dentro dos padrões sociais da elite branca.

Por esses vieses, destaca-se que as personagens protagonistas de cada escritor se diferenciam em suas construções, pois a Chica, de Agripa Vasconcelos 
(2010), se apresenta como uma mulher sádica. Já, a Chica, de João Felício dos Santos (2007) é uma mulher sexualizada. Enquanto, a Chica, de Joyce Ribeiro (2016) é uma boa esposa e mãe. Assim, por meio da classificação de personagem de Forster, em personagens planas e esféricas, percebemos que as três personagens se classificam em categorias diferentes. A Chica de Agripa Vasconcelos (2010) classifica-se esférica, já que ela de escrava submissa passa a ser uma cruel senhora de escravos. "A prova de uma personagem esférica é a sua capacidade de nos surpreender de maneira convincente. Se nunca surpreende, é plana. (CANDIDO, 2017, p.47). Dessa maneira, em contrapartida, a Chica de João Felício dos Santos (2007) e de Joyce Ribeiro (2016) classificam-se planas, pois suas ações não nos surpreendem, são atos já esperados considerando as características empregadas em suas construções.

As discrepâncias entre a construção das personagens também são vistas durante a análise estrutural de Salvatore D'onofrio (1983), à vista disso, o processo de construção da personagem de Agripa Vasconcelos (2010) possui relação sintática sujeito vs objeto e ajudante vs oponente, ademais, apresenta sincretismo atorial e ponto de vista psíquico, efetivando a performance de suas ações, visto que possui todas as competências para isso.

A personagem de João Felício dos Santos (2007) apresenta uma relação sintática e semântica entre protagonista vs antagonista, pois as ações de ambas as personagens impactam uma à outra, justificando-se que o objeto-valor é o mesmo para duas personagens - Xica e Dona Hortênsia, nesse caso, o amor do contratador João Fernandes. Assim, a personagem protagonista possui todas as competências necessárias para alcançar o que deseja.

A personagem de Joyce Ribeiro (2016) estabelece apenas a relação sintática entre sujeito vs objeto, assim, não há progressão em suas ações na narrativa. Ademais, ela não apresenta competências necessárias para suas ações serem dinâmicas, pois apenas apresenta a modalidade do "querer", o que a impossibilita de conseguir o seu objeto-valor, que é a volta de João Fernandes de Oliveira.

Nas observações feitas dos romances se nota que os escritores Agripa Vasconcelos (2010) e João Felício do Santos (2007) escolhem um mesmo termo para usarem no processo de construção de suas personagens, o termo sádica, porém a palavra é interpretada e usada em campos semânticos diferentes do termo. 
Assim, como forma de entender como cada escritor empregou a característica sádica na construção de suas personagens, vejamos a conceituação da palavra sádico e sadismo apresentada pelo dicionário Aurélio (FERREIRA, 2010, p. 619, grifo nosso):

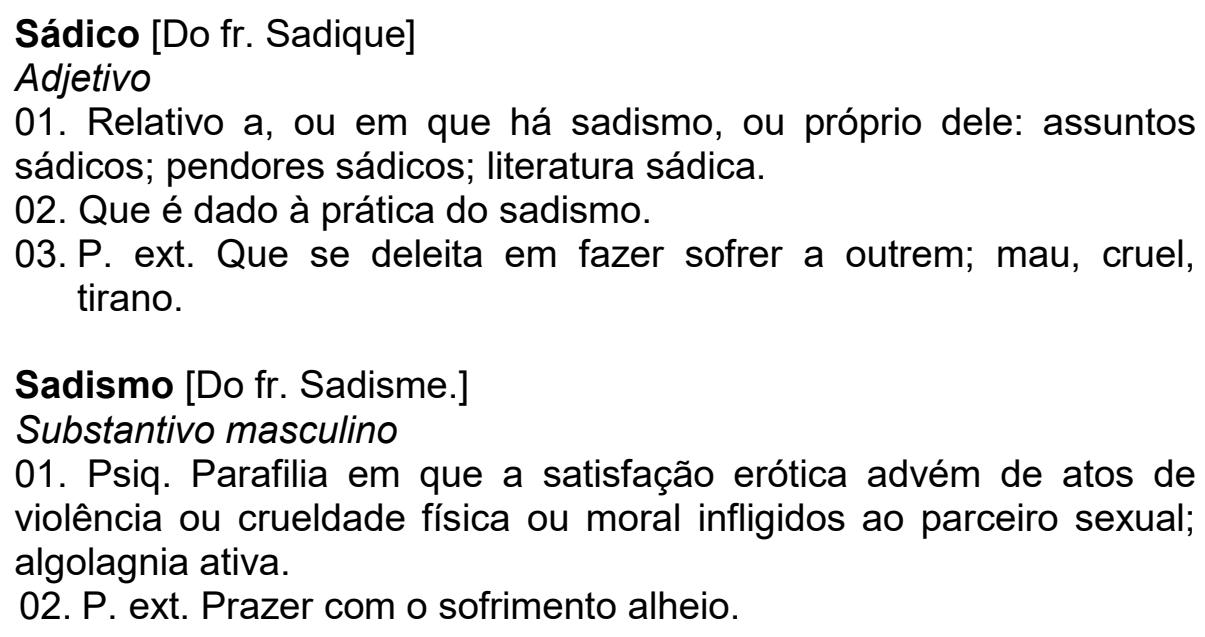

Podemos observar, com a citação anterior, que os termos sádico e sadismo possuem duas conceituações para interpretações, a primeira que caracteriza uma pessoa que comete atos cruentos que resultam em sua satisfação espiritual, e outra que caracteriza a pessoa que, no ato sexual, comete ações que provoquem dor em seu parceiro, como forma de obter prazer sexual em si mesma. No caso das personagens protagonistas dos romances Chica que manda e Xica da Silva, notamos que cada uma segue um dos percursos da significação dos termos.

Assim, a personagem de Agripa Vasconcelos (2010) possui toda a sua construção embasada sobre esse termo pelo viés de cometer atos cruentos que a satisfazem espiritualmente, pois motivada pelo seu desejo pelo objeto-valor ela comete uma sequência de ações que reforçam nela essa construção. Já, a personagem de João Felício dos Santos (2007) é construída com a característica primária da sexualização da personagem, desse modo, nota-se que o objetivo não é construí-la como sádico sexual, mas usar tal característica para realçá-la como uma mulher sedenta por sexo. Em contrapartida, a personagem de Joyce Ribeiro (2016) não apresenta o termo em suas construções sintáticas e semânticas no processo de construção da personagem.

Durante as leituras e análises dos romances sugere-se que os escritores João Felício dos Santos e Joyce Ribeiro possam ter recebido influências em suas 
narrativas da obra Chica que Manda, de Agripa Vasconcelos, pois o escritor foi o primeiro a publicar uma obra sobre essa temática, em 1966.

Notam-se, ao se levar tal hipótese em conta, algumas construções sintáticas e semânticas que evidenciam esse fato. Por esse viés, primeiramente, a obra de João Felício dos Santos (2007) apresenta o termo "Xíca-que-manda" (p.111) em uma construção sintática da protagonista. Ademais, na narrativa é afirmado que "João Fernandes era submisso" (SANTOS, 2007. p.131) e que ela era "mulher da maior autoridade da terra, de maior prestigio e de maiores mandos!" (Idem. p.208). Assim, percebemos que o escritor não faz uso apenas do termo do título da obra de Agripa Vasconcelos (2010), mas trabalha com o sentido dessa frase, em afirmar que Chica era uma mulher que mandava, principalmente, em João Fernandes de Oliveira, que era submisso a ela.

A obra de Joyce Ribeiro (2016) apresenta trechos que nos levam a acreditar que estabelecem diálogos com as outras duas obras citadas. Primeiramente, "Naquele distante arraial além-mar, a Chica "que manda" não tem nenhuma condição de ordenar a volta de seu amado" (RIBEIRO, 2016, p.102), assim, notamos que a escritora faz o uso da construção "Chica que manda", para afirmar que mesmo ela possuindo autoridade social, ela nessa situação não tinha condições em ordenar algo. Ademais, em outro trecho, ela dialoga com a obra de João Felício dos Santos (2007), como vemos: "As pessoas que imaginam Chica da Silva como uma grande devassa, uma devoradora de homens, sussurram nos becos, bem longe dos salões onde poderiam ser ouvidas" (RIBEIRO, 2016, p.116). Desse modo, considerando que por meio da obra de João Felício dos Santos que Chica fica conhecida como "devoradora de homens", entendemos que ela se refere à situação na narrativa como um boato maldoso a imagem da personagem.

As narrativas de Agripa Vasconcelos, de João Felício dos Santos e de Joyce Ribeiro têm, como base para suas criações, o momento histórico das Minas dos diamantes e a pessoa de Francisca da Silva de Oliveira. É importante salientar que, mesmo tendo a mesma base histórica, seus percursos ficcionais diferem-se bastante no que diz respeito a quem foi Chica, pois cada autor apresenta diferentes possíveis respostas para as lacunas deixadas pela historiografia acerca da senhora Francisca.

Os escritores utilizam-se de artificios e estratégias próprias com a intenção de conquistar a credibilidade do leitor, o que pode gerar a impressão de que a obra 
pode ser entendida como uma biografia. Dessa forma, alguns dados ficcionais podem ser confundidos com dados verídicos, que acabam resultando na disseminação de uma imagem estereotipada de Chica da Silva, levando a interpretála como uma mulher que, de fato, correspondia às características dadas a ela pelos romances. Entretanto, há que se fazer separação, sabendo discernir a ficção daquilo que é fato histórico. Enfim, considerando que ambas as narrativas enquadram-se no gênero romance histórico, possuem dados históricos e ficcionais em sua composição. Nenhuma delas, porém, tem como propósito retratar a real pessoa de Francisca da Silva de Oliveira, mas apresentar uma possível leitura de como foi sua vivência no século XVIII, com as cores, os nós e os sabores que a literatura é capaz de nos fornecer.

Enfim, As obras dos três escritores são de suma importância para os estudos sobre o gênero romance histórico. Apesar de diferirem em suas construções, trabalham com o mesmo elemento. Sendo assim, importa entendermos como um mesmo elemento pode possuir diferentes interpretações. Isso, de alguma maneira, fornece o tom principal de cada narrativa, revelando detalhes que a história oficial não consegue fornecer, devido à pretensão em relatar uma verdade - o mesmo já não se pode dizer da ficção. 


\section{REFERÊNCIAS:}

ALGRANTI, Leila Mezan. Famílias e vida doméstica. In: SOUZA, Laura de Mello e (org.). História da vida privada no Brasil. São Paulo: Companhia das Letras, 1997, p.62-120.

ANDRADE, Celeste Maria Pacheco de. SILVA, Thaíse Araújo da. Viva o povo brasileiro: Interface entre literatura e história. Litterata, Santa Cruz, v. 2, n. 5, p. 105121, dez. 2015.

ARAÚJO, Emanuel. A arte da sedução: Sexualidade feminina na colônia. In: DEL PRIORE, Mary; BASSANEZI, Carla Beozzo. Histórias das mulheres no Brasil. 10. ed. São Paulo: Editora Contexto, 2004.

ARÁUJO, Rafaela Albuquerque Valença de. Abordagem Qualitativa Na Pesquisa Em Administração: Um Olhar Segundo a Pragmática da Linguagem. ANPAD. 2013. Disponível em: <http://www.anpad.org.br/admin/pdf/EnEPQ196.pdf>. Acesso em: 08 dez. 2019.

BASTOS, Alcmeno. O romance histórico no romantismo brasileiro (Além de Alencar). WORDPRESS. 2011. Disponível em: http://www.alcmeno.com/wordpress/wpcontent/arquivos/romance-historico-no-romantismo.pdf. Acesso em: 01 jun. 2020.

BAUMGARTEN, Carlos Alexandre. O romance histórico: a vitalidade de um gênero. Letrônica, Porto Alegre, v. 1, n. 9, p. 106-110, jun. 2016.

BRAIT, Beth. A personagem. 3ed. São Paulo: Ática, 1985.

BRAZ, Luiza. Precisamos falar sobre a hipersexualização das meninas. Medium, 2017. Disponível em: https://medium.com/@LuizaBraz/precisamos-falar-sobre-ahipersexualiza\%C3\%A7\%C3\%A3o-das-meninas-. Acesso em: 06 jan 2020.

CALEIRO, Regina Célia Lima; NASCIMENTO, Vinicius Amarante. Chica que manda: História e Literatura no mundo das representações de Agripa Vasconcelos. História e Perspectivas, Uberlândia, v. 1, n. 45, p. 217-254, dez. 2011.

CALEIRO, Regina Célia Lima; NASCIMENTO, Vinicius Amarante. Chica/ Xíca da Silva: Representações do mito na memória de Joaquim Felício dos Santos e no romance de João Felício dos Santos. Aedos, Rio Grande do Sul, v. 16, n. 7, p. 441464, jul. 2015.

CANDIDO, Antonio et al. A personagem de ficção. 13. ed. São Paulo: Editora Perspectiva, 2017.

CARVALHAL, Tânia Franco. Literatura comparada. 4. ed. São Paulo: Ática, 2006.

CORTELETI, Marco Antônio. Pesquisa contesta mito de Chica da Silva. UFMG. Disponível em: <https://www.ufmg.br/boletim/bol1207/pag4.html>. Acesso em: 12 jan. 2020. 
COSTA, Emília Viotti. Da monarquia à república: momentos decisivos. 6. ed. São Paulo: Fundação Editora da UNESP, 1999.

CUNHA, Patrícia da Silva Simões da. PAIVA, Jéssica Souza de. A erotização da mulata na cultura brasileira. V Seminário Internacional Enlaçando Sexualidades. Bahia, 2017.

D'ONOFRIO, Salvatore. A personagem de ficção p.55-62. In: D'ONOFRIO, Salvatore. O texto literário: Teoria e aplicação. São Paulo: Duas cidades, 1983.

ESTEVES, Antônio R. O romance histórico brasileiro contemporâneo (19752000). São Paulo: Ed. UNESP, 2010.

FERREIRA, Aurélio Buarque de Holanda. Dicionário da língua portuguesa. 5. ed. Curitiba: Positivo, 2010.

FIGUEIREDO, Luciano. Mulheres nas Minas Gerais. In: DEL PRIORE, Mary; BASSANEZI, Carla Beozzo. Histórias das mulheres no Brasil. 10. ed. São Paulo: Editora Contexto, 2004.

FIGUEIREDO, V. F. de. Da alegria e da angústia de diluir fronteiras: o romance histórico, hoje, na América Latina. In.: CONGRESSO ABRALIC. Rio de Janeiro: Abralic, 1997.

FREYRE, Gilberto. Casa-grande \& senzala: formação da família brasileira sob o regime da economia patriarcal. 51. ed. rev. São Paulo: Global, 2006.

FURTANO, Júnia Ferreira. Chica da Silva e o contratador dos diamantes. 1. ed. São Paulo: Companhia das Letras, 2003.

GASS, William H. O conceito de personagem na ficção. In: ------. A ficção e as imagens da vida. São Paulo, Cultrix, 1974, p.42-59.

Gil, Antonio Carlos, Como elaborar projetos de pesquisas. Antonio Carlos Gil. 4. ed. São Paulo: Atlas, 2002

HUTCHEON, Linda. Poética do pós-modernismo: História teoria ficção. Tradução Ricardo Cruz. Rio de Janeiro: Imago.

JAUS, Hans Robert. A história da literatura como provação à teoria literária. Tradução de Sérgio Tellaroli. São Paulo: Ática, 1994.

LUKÁCS, Gyorgy. O romance Histórico. 1. ed. São Paulo: Boitempo, 2011.

MANCINI, Mara Sylvia Vasconcellos. MENON, Maurício Cesar Menon. SILVA, Sandro Adriano. Agripa Vasconcelos: do poeta ao romancista das gerais. São Paulo: Pedro \& João Editores, 2018.

MARCO, Valeria de. O Romance histórico de José de Alencar. Revista de Letras, São Paulo, v. 1, n. 25, p. 106-113, jun. 2009.

MENTON, Seymour. La nueva novela histórica de la América Latina, 1979-1992. México: Fondo de Cultura Económica, 1993. 
MOTT, Luiz. Cotidiano e vivência religiosa: entre a capela e o calundu. In: SOUZA, Laura de Mello e (org.). História da vida privada no Brasil. São Paulo: Companhia das Letras, 1997.

NASCIMENTO, Abdias do. O genocídio do negro brasileiro: processo de um racismo mascarado. São Paulo: Perspectiva, 2016.

NITRINI, Sandra. Literatura comparada: história, teoria e crítica. 3. ed. São Paulo: EDUSP, 2015.

NOVAIS, Fernando A. Condições da Privacidade na Colônia. In: SOUZA, Laura de Mello e (org.). História da vida privada no Brasil. São Paulo: Companhia das Letras, 1997.

NWABASILI, Mariana Queen. As Xicas da Silva de Cacá Diegues e João Felício dos Santos: traduções e leituras da imagem da mulher negra brasileira. 284f. 2017. Dissertação (Mestrado) - Programa de Pós-graduação em Meios e processos audiovisuais: Cultura Audiovisual e Comunicação, Escola de Comunicação e Artes da Universidade de São Paulo, São Paulo.

PERACHI, Camila Taiara et al. Construções freudianas acerca do sadismo e do masoquismo: uma ruptura com a tradição médica. Fisioterapia em Movimento, Curitiba, v. 32, n. 79, p.71-83, mar. 2014.

DEL PRIORE, Mary. Ritos da Vida Privada. In: SOUZA, Laura de Mello e (org.). História da vida privada no Brasil. São Paulo: Companhia das Letras, 1997.

REIS, Carlos. Estudos Narrativos: A questão da personagem ou a personagem em questão. In: REIS, Carlos. Pessoas do livro. Estudos sobre a personagem. Coimbra, Imprensa da Universidade de Coimbra, abril 2015. Disponível em: < https://pombalina.uc.pt/files/previews/106616 preview.pdf>. Acesso em: 24 fev. 2019.

REIS, Roberto. A permanência do círculo: hierarquia no romance brasileiro. Niterói, EDUFF; Brasília: INL, 1987.

RIBEIRO, Joyce. Chica Da Silva: Romance De Uma Vida. 1ed. São Paulo: Planeta, 2016.

SÃO PAULO, 5 : 22-24. In: BÍBLIA. Português. Sagrada Bíblia Católica: Antigo e Novo Testamentos. Tradução de José Simão. São Paulo: Sociedade Bíblica de Aparecida, 2008.

SANTOS, Donizeth Aparecido dos. O Continente: Um romance histórico tradicional ou um novo romance histórico? Akrópolis, Umuarama, v. 3, n. 17, p. 123-129, set. 2009.

SANTOS, Elizete de Souza de Oliveira; BUCHER, Bernadeth. Transtorno parafiliaco: Sadismo e Masoquismo. Conexão Eletrônica, Três Lagoas, v. 12, n. 1, p.726-734, jan. 2018.

SANTOS, João Felício dos. Xica da Silva. $3^{\circ}$ ed. Rio de Janeiro: José Olympio, 2007. 
SANTOS, Jorge Fernando dos. Relações Literárias João Felício dos Santos. O Estado de Minas. Disponível em: <http://www.tirodeletra.com.br/relacoes/JoaoFeliciodosSantos.htm>. Acesso em: 03 mar. 2017.

SOETHE, Paulo Astor. Literatura comparada. Curitiba: IESDE Brasil, 2009.

TEIXEIRA, Carla Lavorati; BORGES, Níncia Cecília Ribas. Diálogos entre ficção e história: do romance histórico clássico ao novo romance histórico. Odisseia, Rio Grande do Norte, v. 6, n. 1, p. 1-8, dez. 2010.

TELES, Lanna Moura Sá; ADI, Ashjan Sadique. Hipersexualização das mulheres negras: aspectos sócio-históricos e a influência da mídia. AVEF, 2020.

TIMÓTEO, 2: 9-15. In: BÍBLIA. Português. Sagrada bíblia católica: Antigo e Novo Testamentos. Tradução de José Simão. São Paulo: Sociedade Bíblica de Aparecida, 2008.

VAINFAS, Ronaldo. Homoerotismo feminino e o Santo Ofício. In: PRIORE, Mary Del. Histórias das mulheres no Brasil. 10. ed. São Paulo: Contexto, 2004.

VASCONCELOS, Agripa. Chica que manda. Belo Horizonte: Itatiaia, 1966.

VASCONCELOS, Agripa. Chica que manda. 1. ed. Belo Horizonte: Editora Itatiaia, 2010.

WEINHARDT, Marilene. Considerações sobre o romance histórico. Letras, Curitiba, v. 43, n. 1, p.49-59, jan. 1994.

WHITE, Hayden. Teoria literária e escrita da história. Estudos Históricos, Rio de Janeiro, v. 7, n. 13, p.21-48, 1991. 